\title{
THE AULACOSTEPHANIDAE (AMMONOIDEA) OF THE OXFORDIAN/KIMMERIDGIAN BOUNDARY BEDS (UPPER JURASSIC) OF SOUTHERN ENGLAND
}

\author{
by JOHN K. WRIGHT \\ Department of Geology, Royal Holloway, University of London, Egham, Surrey, TW20 0EX, UK; e-mail j.wright@es.rhul.ac.uk \\ Typescript received 30 August 2003; accepted in revised form 14 September 2009
}

\begin{abstract}
Four areas in southern England centred on Swindon and Westbury (Wiltshire), Bourton (north Dorset) and the Dorset coast near Weymouth (south Dorset) have yielded well-preserved late Oxfordian and early Kimmeridgian (Upper Jurassic) ammonites in abundance. These ammonites belong principally to the aulacostephanid genera Ringsteadia and Pictonia, and their microconch equivalents Microbiplices and Prorasenia. Systematic descriptions of these genera are included herein. Within the zonal and subzonal sequence of the English Oxfordian/Kimmeridgian Stage boundary beds, the established subdivision of
\end{abstract}

the Late Oxfordian Pseudocordata Zone into Pseudoyo, Pseudocordata and Evoluta Subzones is confirmed. In the Early Kimmeridgian Baylei Zone, however, the evidence is that the sequence throughout much of southern England is incomplete compared with more complete sequences such as that at Staffin in the Isle of Skye, with the presence of only one faunal biohorizon, the densicostata horizon.

Key words: Oxfordian, Kimmeridgian, southern England, ammonites, biostratigraphy.
The genera Ringsteadia and Pictonia, and their respective microconch equivalents Microbiplices and Prorasenia, comprise a major constituent of the late Oxfordian and early Kimmeridgian ammonite faunas of North-West Europe. They characterise the Sub-Boreal Province (Text-fig. 1), predominantly in England, northern France and western Germany and have been used extensively as zonal/subzonal indices throughout the province. Their range extends northwards well into the Boreal Province.

South and southeastwards in the Sub-Mediterranean Province, most records of Ringsteadia in the literature have proved to be of a separate, younger, Jura/Pomeranian endemic group homeomorphic with Ringsteadia, but in fact having only a very ancestral connection with the North-West European faunas (Arkell 1956; Wierzbowski 1970).

Perhaps surprisingly, the British aulacostephanid faunas have attracted only a limited amount of research. Ringsteadia is comparatively well known because of the pioneering work of Salfeld (1917) who monographed the Ringsteadia faunas of Wiltshire and Dorset. Buckman (1919-30) figured several specimens of Ringsteadia. Arkell (1935, p. xxxii, 1940, p. lxv) promised a revision of Ringsteadia, but this task was later abandoned as 'there are other tasks more urgent' (Arkell 1947a, p. 352), and
Arkell confined his attention solely to Microbiplices. Sykes and Callomon (1979) subsequently described Upper Oxfordian Amoeboceras, but only one species of Ringsteadia, from the Isle of Skye. Matyja et al. (2006) figured several Ringsteadia and Microbiplices from this locality, but, until the present work, there has been no comprehensive modern study of these genera. Important work on Ringsteadia in the doctoral thesis of Morris (1968) remains unpublished.

Pictonia and Prorasenia have never been subject to detailed modern study by British authors. Of the limited work that has been performed, it is worth mentioning Buckman (1924b, 1927) and Spath (1935), who described respectively two new species of Pictonia and two of Prorasenia. Significant faunas of Pictonia and Prorasenia from the Isle of Skye were figured by Matyja et al. (2006). Numerous specimens of Pictonia from northern France were figured by Tornquist (1896), but for many years this material lacked a satisfactory modern account. This has now been rectified by Hantzpergue (1989). Recent stratigraphical research on the Kimmeridgian of Normandy has been summarized by Gallois (2005). Specimens of Pictonia from Greenland have been described by Birkelund and Callomon (1985) and from Siberia by Mesezhnikov (1969). Sub-Mediterranean specimens recorded as Pictonia lack the regular deep 


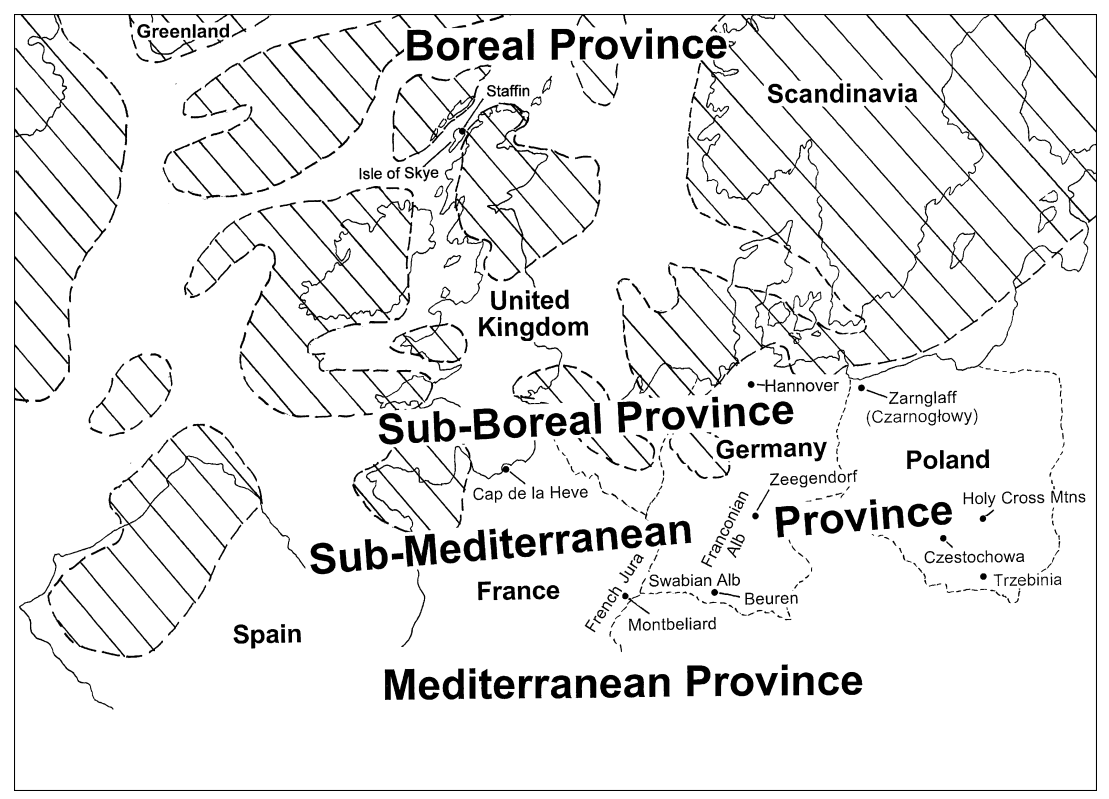

TEXT-FIG. 1. Extent of the Boreal, Sub-Boreal, Sub-Mediterranean and Mediterranean provinces across Europe, with the distribution of land and sea in the latest Oxfordian, and the principal continental localities mentioned in the text (after Ziegler 1982, Cope 1995 and Matyja and Wierzbowski 1995).

constrictions and flared ribs characteristic of Boreal and Sub-Boreal forms and should be regarded as a separate endemic group (Pachypictonia) not directly connected. Specimens which are taken to be the microconch counterpart of Pictonia, are closely similar to the German Prorasenia of Schindewolf (1925), and this name may also be used for the British forms. The aim of the present paper is to provide the first full descriptions of uppermost Oxfordian and lowermost Kimmeridgian aulacostephanids from southern England based on the latest understanding of the stratigraphy of these beds (Wright 2003).

\section{AULACOSTEPHANID TAXONOMY - 'GENERA', 'SUBGENERA' AND 'SPECIES'}

The extreme variability seen in aulacostephanids, particularly Ringsteadia, causes significant problems in taxonomy. Early workers followed conventional classifications in terms of typological morphospecies and morphogenera having stratigraphical ranges (often not specified or even known) - the 'vertical' classification. Such classifications are purely subjective, arbitrary and hence unnatural. Classification today strives towards a natural taxonomy in terms of successions of 'horizontal' biospecies (see e.g. Sylvester-Bradley (1956), or Callomon (1963, 1969, 1981, 1985) for ammonites in particular). These are the phyletic transients of an evolving lineage, the chronospecies or biospecies of some authors. Some biospecies can be made up of half a dozen or more morphospecies. However, morphospecific names con- tinue to be useful in order to describe and define the range of variation existing within a biospecies, and, in general, pre-existing specific names are retained here. The retention of some of these names is necessary in particular in cases where formal subzones have been named after morphospecies. No new specific names have been introduced, however, and where morphotypes have been found whose morphologies are not covered by existing morphospecies, these are described as variants of the closest morphospecies.

Groups of similar morphospecies have then been grouped into genera. In a very varied population, different generic names may have been applied to extreme members of one continuously variable population. An attempt is made here to allocate all morphospecies of one continuously variable biospecific taxon to one genus. The procedure of Arkell and others of using subgenera to group together assemblages of similar morphospecies is not adopted. Such groupings are best referred to by the name of their most typical morphospecies. When dividing up a single evolving lineage into successive genera, this can only be performed on grounds of convenience, perhaps historically influenced.

Dimorphism also presents taxonomic problems. Almost all ammonite biospecies occur as dimorphs, the assumption being that the microconch forms were the males and the macroconch forms the females (Makowski 1963). The difference in adult size can be enormous - in the case of Ringsteadia and its microconch counterpart Microbiplices, $30 \mathrm{~mm}$ (microconch) and $450 \mathrm{~mm}$ (macroconch). In some cases, authors have already decided to allocate one generic name for the combined dimorphic pair. However, the changes in characters used to define successive micro- 
conch genera do not always occur at the same time as those used to define the successive macroconchs. This being almost certainly the situation with RingsteadiaPictonia and Microbiplices-Prorasenia, separate morphogeneric names for macroconchs and microconchs are retained here.

\section{AMMONITE STRATIGRAPHY}

This study describes ammonites collected from the Oxfordian/Kimmeridgian boundary beds principally in southern England. Localities in England referred to in the text are marked in Text-figure $2 \mathrm{~B}-\mathrm{D}$. The ammonites have been collected from predominantly clay facies rocks, much of sedimentation during the latest Oxfordian and Kimmeridgian in England being argillaceous in nature. Beds are allocated to the Ampthill Clay Formation succeeded by the Kimmeridge Clay Formation in northern

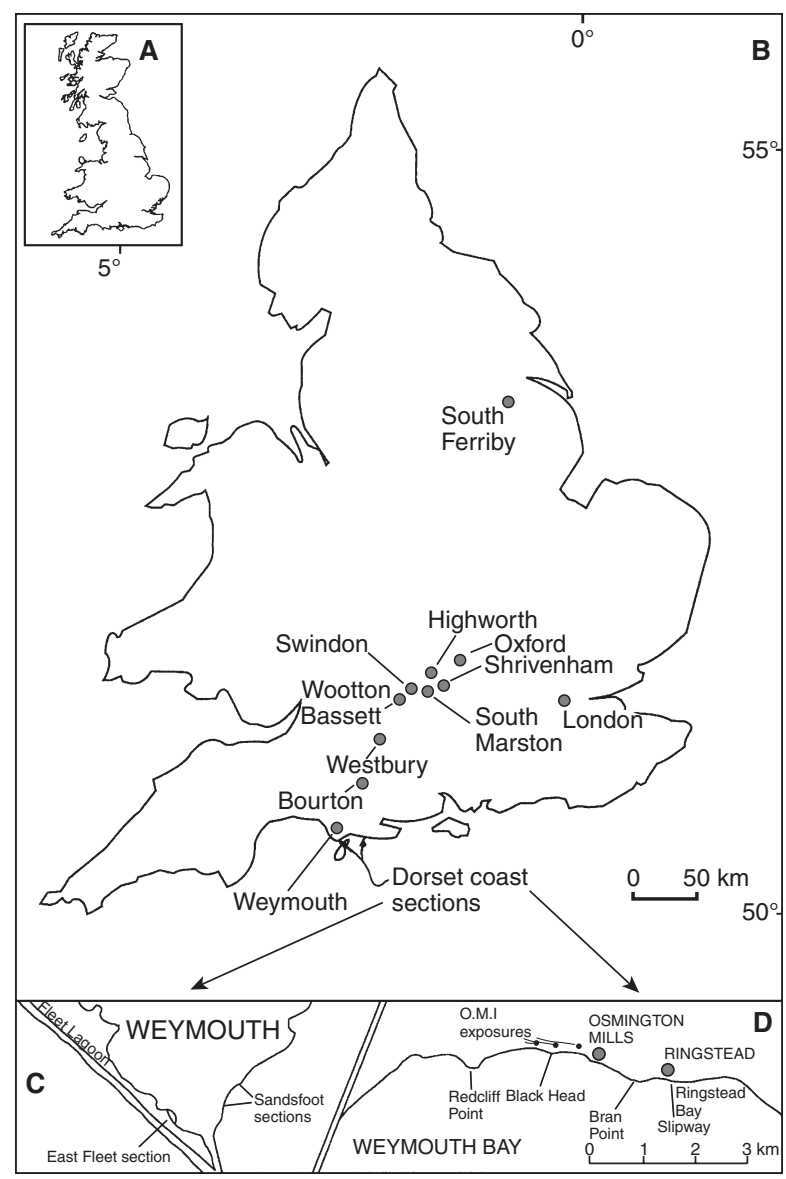

TEXT-FIG . 2. Great Britain (A), England showing principal localities mentioned in the text (B), Weymouth (south Dorset), showing localities sampled (C) and Weymouth Bay (south Dorset), showing localities sampled (D).
England and the northern part of southern England. In southern England from Westbury southwards, the latest Oxfordian is more arenaceous in facies, and the beds are allocated to the Sandsfoot Formation succeeded by the Kimmeridge Clay Formation.

In this southern area, sandy and ferruginous beds form convenient marker beds dividing up the clay succession (Text-fig. 3). The Sandsfoot Grit Member and associated Westbury Ironstone Member separate the Sandsfoot Clay and Ringstead Clay members, clays that are equivalent in age to parts of the Ampthill Clay succession of more northern areas. The Osmington Mills Ironstone Member marks the highest Sandsfoot Formation, succeeded by the basal Kimeridge Clay Inconstans Bed, sandy, often phosphatic clays containing abundant, well-preserved ammonites.

Within the clay members and formations, ammonites are often crushed and poorly preserved, but at certain horizons, the development of micrites and ooidal ironstones has resulted in the preservation of ammonites in three dimensions. The Marston Ironstone Bed of the Swindon area is a typical example (Wright 2003). A detailed study of the stratigraphy and sedimentology of these beds has been published by the author previously (Wright 2003). Logs of the sequences yielding ammonites figured here are given in Text-figure 3.

Marston Ironstone. This is a $0.6 \mathrm{~m}$ bed composed of limonite-ooid clay containing beautifully preserved micrite-filled ammonites present in the middle part of the Ampthill Clay Formation in the Wootton BassettSwindon-South Marston-Shrivenham area of Wiltshire (Text-fig. 3). Substantial new exposures of this bed were created during the construction of the Keypoint Industrial Distribution Site [the Keypoint site] at South Marston, east of Swindon, in 1999-2001.

A complete list of the macrofauna was published by Wright (2003). Several of the best aulacostephanids are figured here in Plates 1-5. The following morphospecies from this bed are described herein: Ringsteadia pseudocordata (Blake and Hudleston), R. anglica Salfeld, $R$. brandesi Salfeld, R. pseudoyo Salfeld, R. sphenoidea Buckman, R. marstonensis Salfeld, R. bassettensis Spath and Microbiplices cf. anglicus Arkell.

Westbury Ironstone. This $4-5 \mathrm{~m}$ thick bed of ooidal ironstone, included in the Sandsfoot Formation, is present in the immediate vicinity of Westbury, Wiltshire (Talbot 1974; Wright and Cox 2001) (Text-figs 2-3).

There is no opportunity of new ammonite collecting at present, but many ammonites from Westbury are scattered through museum collections, and the following aulacostephanid morphospecies are recognised herein: Ringsteadia pseudoyo, R. pseudocordata, R. brandesi, 


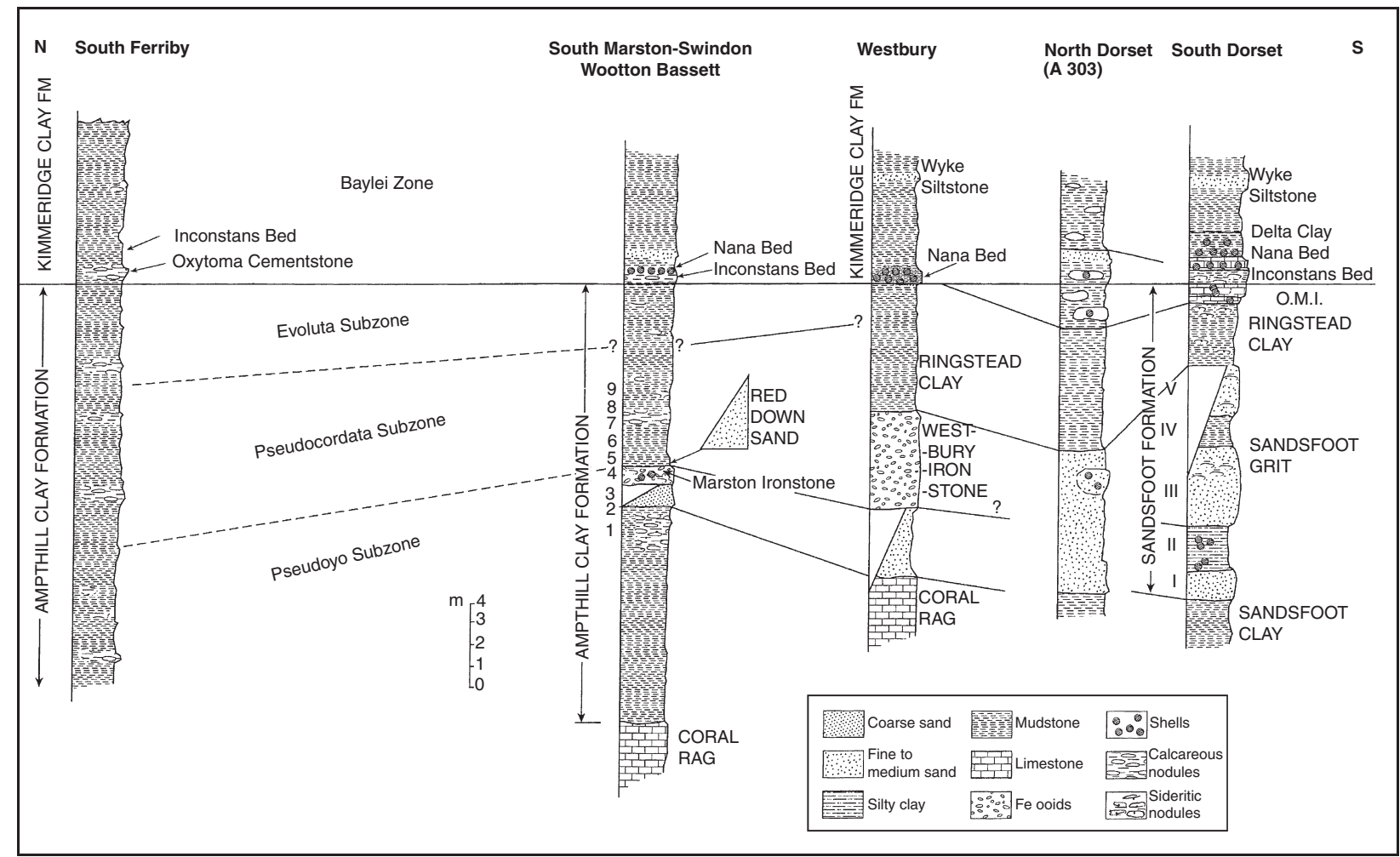

TEXT-FIG. 3. Logs of the Oxfordian/Kimmeridgian boundary beds at South Ferriby, Swindon, Westbury and in Dorset (after Wright, 2003, fig. 2). I to V in south Dorset column subdivisions of the Sandsfoot Grit of Brookfield (1978) and Wright (1986). O.M.I., Osmington Mills Ironstone, passing laterally into the Ringstead Coral Bed. For location of sites see Text-figure 2.

R. anglica, R. marstonensis, R. bassettensis and Microbiplices anglicus.

Sandsfoot Grit. A series of sandstones, sandy clays and sandy ooidal ironstones is present in the Upper Oxfordian succession of the Sandsfoot Formation between Weymouth and Bran Point, Dorset (Wright 1986, 1998; Text-fig. 3).
Although ammonites are frequently poorly preserved, occasional specimens preserved in calcareous or phosphatic concretions can be very well preserved. A list of the macrofauna was published by Wright (1998). The following morphospecies, all from Unit III (Text-fig. 3), are described here: Ringsteadia brandesi, R. marstonensis and Microbiplices anglicus.

\section{EXPLANATION OF PLATE 1}

Fig. 1. Ringsteadia pseudoyo Salfeld, SM228, $\times 0.75$.

Fig. 2. Ringsteadia brandesi Salfeld, SM 229, $\times 0.6$.

Fig. 3. Ringsteadia pseudoyo Salfeld, SM192, $\times 0.8$.

Fig. 4. Ringsteadia marstonensis Salfeld, SM37, $\times 0.95$.

Fig. 5. Ringsteadia pseudocordata (Blake and Hudleston) var nudus nov., type of var., SM72, $\times 0.55$.

Figs 6-8. Microbiplices anglicus Arkell, Sandsfoot Grit, Pseudocordata Subzone, ×1.0; 6-7, Sandsfoot Castle, Weymouth, RHUL ic376a; 8, Black Head, DC61.

Fig. 9. Prorasenia sp., Osmington Mills Ironstone, East Fleet section, NHM C75301, ×1.0. All specimens except 6-9 from the Marston Ironstone, Pseudoyo Subzone, Keypoint site, South Marston; 1-4 septate inner whorls; 9 is a largely complete microconch adult with the test preserved. Scale bars represent $10 \mathrm{~mm}$. No scale bar = natural size.

NB: On this and following plates, the end of the phragmocone is marked by an X. Where it is not clear in the figure, specimens that are wholly septate and portions of nonseptate body chambers are described as such in the plate descriptions; in some cases, the presence and extent of suture lines cannot be determined. 
PLATE 1

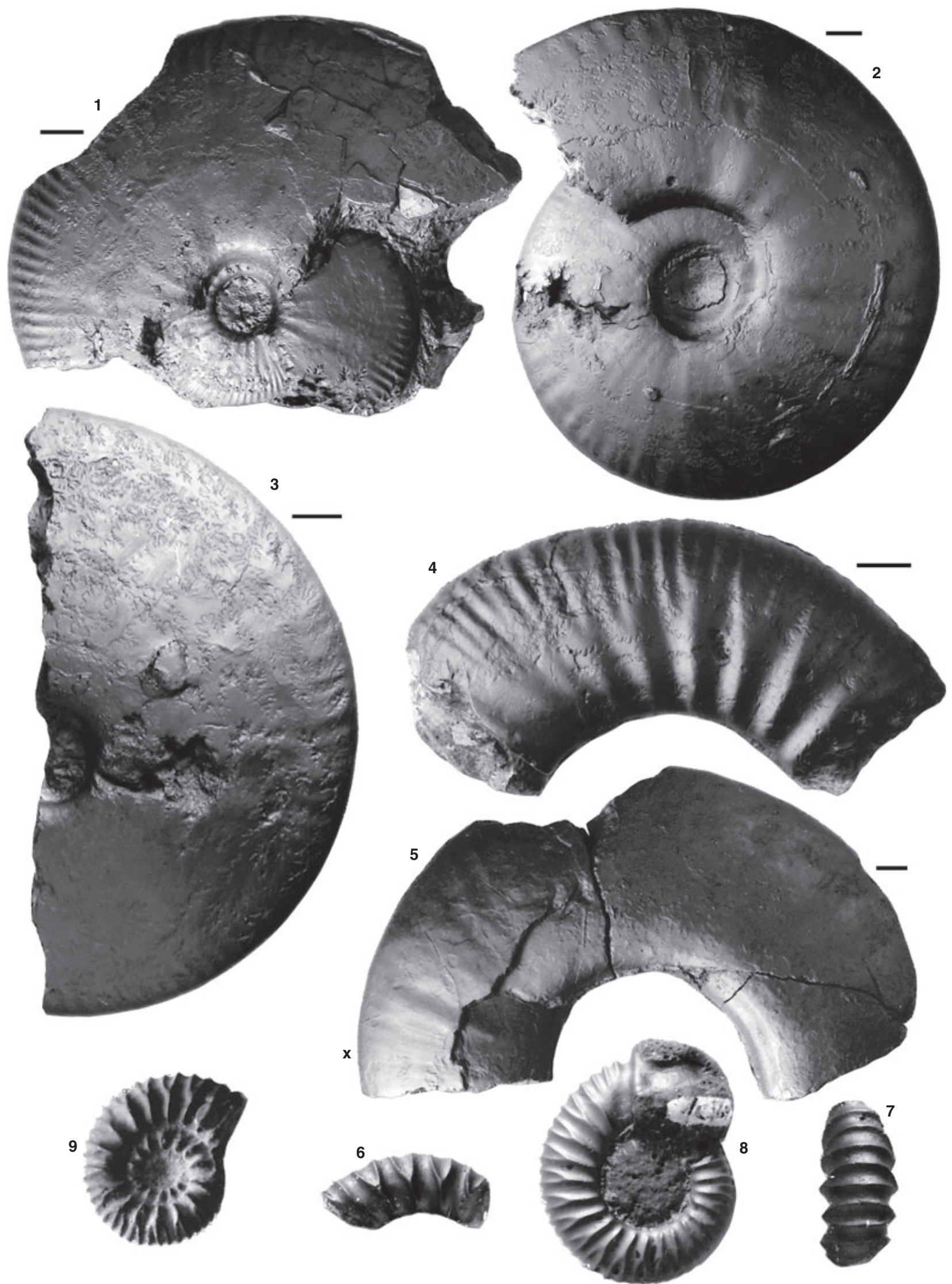

WRIGHT, Microbiplices, Prorasenia, Ringsteadia 
Osmington Mills Ironstone. This sandy, micritic, limoniteooid ironstone occupies the highest part of the Sandsfoot Formation (Text-fig. 3), where it represents the top of the Oxfordian succession between Weymouth and Ringstead Bay (Brookfield 1978; Wright 2003; Williams 2003). It rests with a sharp, erosive break on the Ringstead Clay Member. In the vicinities of Black Head and the Ringstead Bay slipway (Text-fig. 2D), the ironstone passes laterally into coralliferous, micritic limestone named the Ringstead Coral Bed (Wright 2003).

A number of well-preserved Ringsteadia have been collected by the author, and many more are to be found in museum collections. The following morphospecies are described herein: R. frequens Salfeld, R. evoluta Salfeld, R. pseudoyo, R. marstonense and Prorasenia sp. As was noted by Wright (2003), almost all previous records of ammonites from the underlying Ringstead Clay have proved to be erroneous, the specimens in fact coming from the basal part of the overlying Osmington Mills Ironstone, which is often argillaceous.

Inconstans Bed. Across much of southern England, the lowest $0.5-1.0 \mathrm{~m}$ of the Kimmeridge Clay Formation comprises a distinctive, shelly, sandy clay or argillaceous sandstone containing phosphatised micrite-filled Pictonia and Prorasenia as well as a prolific bivalve-brachiopod fauna (Brookfield 1978). This bed, which rests with an unconformity on the underlying strata (Wright, 2003, fig. 8), was named by Arkell $(1933,1947 b)$ the Inconstans Bed after the common occurrence of the brachiopod Torquirhynchia inconstans (J. Sowerby).

Substantial numbers of ammonites from the Inconstans Bed are present in museum collections. The following morphospecies are described herein: Pictonia densicostata Buckman, P. seminudata (Buckman) and Prorasenia hardyi Spath.

A large Inconstans Bed ammonite fauna was collected from temporary exposures at Blagrove Farm and Windmill Hill, on the south-western outskirts of Swindon, by J. H. Callomon in the 1990s. The specimens are now in the Oxford University Museum. A review of the collection shows that the proportions of the morphospecies and varieties present are almost exactly the same as in the Inconstans Bed of south Dorset.

Others. During construction of the A303 Bourton bypass in north Dorset in 1991, tantalising glimpses of well-preserved Oxfordian/Kimmeridgian boundary beds faunas were seen (Bristow et al. 1991). Unfortunately, the strata, of relatively deep water facies, were not continuously exposed in the road cutting, and the correlation of several small exposures was necessary to produce a tentative section (Bristow et al. 1991, p. 141; Text-fig. 3).

A Late Oxfordian ammonite fauna from the Ringstead Clay Member, probably equivalent in age to the Osmington Mills Ironstone, comprises micrite-filled body chambers of Ringsteadia evoluta with occasional Ringsteadia frequens, the inner whorls crushed flat except in occasional calcareous concretions.

An Early Kimmeridgian ammonite fauna comprising Pictonia sp. and Prorasenia cf. hardyi is contained within very fossiliferous concretions also containing well-preserved bivalves and gastropods. This latter fauna was correlated with that of the Inconstans Bed by Bristow et al. (1991). However, the Inconstans Bed, consisting of silty clay containing Pictonia sp. was exposed here in a temporary excavation at ST 78153050 in 2003. The concretions yielding the Early Kimmeridgian fauna of Bristow et al. (1991) occur below this level within extremely fine-grained mudstone and may represent the earlier flodigarriensis horizon of Matyja et al. (2006). An excellently preserved Rasenia cymodoce (d'Orbigny) was collected from higher beds. All these specimens are in the BGS collection at Keyworth.

Suggestions of flodigarriensis horizon faunas were also seen in the M40 excavations in Oxfordshire (Prorasenia bowerbanki Spath and Amoeboceras praebauhini Salfeld, OUM Collection) and in the basal Kimmeridgian at South Ferriby Pit (P. bowerbanki, described below).

\section{EXPLANATION OF PLATE 2}

Fig. 1. Ringsteadia anglica Salfeld, trans. to R. pseudocordata, Keypoint site, South Marston, SM135, $\times 0.6$;

Fig. 2. Ringsteadia brandesi Salfeld, Keypoint site, South Marston; SM138, $\times 0.65$.

Fig. 3. Ringsteadia brandesi Salfeld, South Marston railway cutting, YORYM:2004.179, $\times 0.8$.

Figs 4-6. Ringsteadia brandesi, Sandsfoot Grit, Pseudocordata Subzone, Sandsfoot Castle, Weymouth, $\times 1.0$; 4-5, RHUL ic105; 6 , DC58. Figs 7-8. Microbiplices cf. anglicus. Keypoint site, South Marston, SM163, ×1.0.

Fig. 9. Ringsteadia sphenoidea Buckman, Keypoint site, South Marston, SM96, $\times 0.75$.

All specimens except 4-6 from the Marston Ironstone, Pseudoyo Subzone; all septate inner whorls except 7-8. Scale bars represent $10 \mathrm{~mm}$. No scale bar = natural size. 
PLATE 2
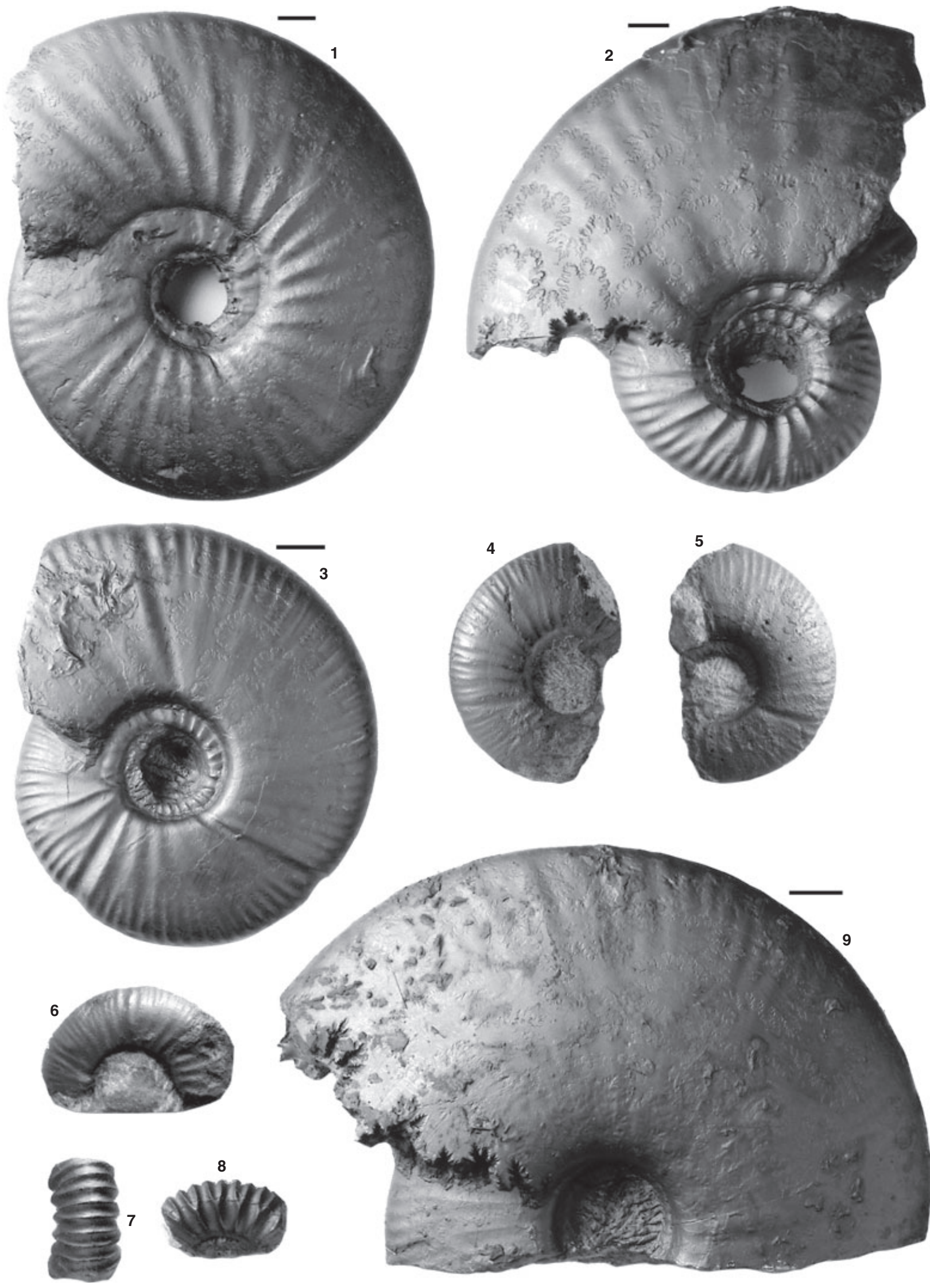


\section{AMMONITE ZONES AND SUBZONES IN THE SUB-BOREAL UPPERMOST OXFORDIAN - LOWERMOST KIMMERIDGIAN}

The standard chronostratigraphical classification, based on Matyja et al. (2006), is shown in Text-figure 4.

\section{UPPERMOST OXFORDIAN}

\section{Pseudocordata zone}

The seven 'species' of Ringsteadia described by Salfeld (1917) were recorded indiscriminately throughout the Pseudocordata Zone, with the exception of $R$. evoluta at the top. Morris (1968) was able to demonstrate that in each of the three fossiliferous units, Marston Ironstone, Westbury Ironstone/Sandsfoot Grit and Osmington Mills Ironstone, one morphotype occurred more commonly than at the other horizons. These three faunas of Ringsteadia were characterised by $R$. pseudoyo, R. pseudocordata and $R$. evoluta, respectively. These subdivisions were listed formally as subzones by Sykes and Callomon (1979) and Wright (1980) and are listed as such in Text-figure 4, although they were subsequently used as faunal horizons by Schweigert and Callomon (1997).

The Pseudoyo Subzone, as typified by the fauna of the Marston Ironstone (197 specimens), is dominated by the evolute marstonensis group (51\%). R. pseudocordata and $R$. marstonensis are equally predominant, and the coarsely ribbed $R$. bassettensis only amounts to $10 \%$ of the group. The involute brandesi group is also abundant (32\%), and the highly involute pseudoyo group amounts to only $17 \%$ of the fauna. Prof. J. H. Callomon (pers. comm. 1998) has suggested that the low proportion of the pseudoyo group here is because the Marston Ironstone fauna lies near the top of the Pseudoyo Subzone.

It is not possible to do a similar statistical analysis of the Westbury Ironstone/Sandsfoot Grit Ringsteadia fauna
(Pseudocordata Subzone), as collections are limited (only 43 specimens seen). The proportion of morphotypes is similar to that of the Pseudoyo Subzone excepting for the scarcity of $R$. pseudoyo in the Westbury fauna (pseudoyo group c. $2 \%$, brandesi group c. $40 \%$, marstonensis group $c$. $60 \%)$.

The ammonite fauna of the Evoluta Subzone (Osmington Mills Ironstone/Ringstead Coral Bed fauna) is quite distinctive (52 specimens). There is still a substantial range in variation of shell shape, although not as marked as in the earlier subzones. R. pseudoyo is still present $(6 \%)$. Moderately involute forms are represented by the oval-whorled $R$. frequens (40\%). Slim, evolute forms (R. evoluta, 52\%) may be markedly constricted. One round-whorled form resembles R. marstonensis.

\section{LOWERMOST KIMMERIDGIAN}

\section{Baylei zone}

Matyja et al. (2006) divided the Baylei Zone into two subzones, a Densicostata Subzone overlain by a Normandiana Subzone (Text-fig. 4).

A succession of four, possibly five faunal horizons of Pictonia has been identified in the Sub-Boreal Province, combining evidence from localities between East Greenland (Birkelund and Callomon 1985), Staffin, Scotland (Morris 1968, later revisions summarized in Morton and Hudson 1995; Matyja et al. 2006), South Ferriby, Lincolnshire (Schweigert and Callomon 1997), Swindon and Dorset (discussed herein) and Normandy (Hantzpergue 1989).

1. P. flodigarriensis horizon: identified at Staffin and present in England in basinal areas such as north Dorset (Wessex Basin). Overstepped in shelf areas by the densicostata horizon.

2. $P$. densicostata horizon: identified at Staffin and in England at South Ferriby via Oxford and Swindon to the Dorset coast in the Inconstans Bed and missing in a nonsequence in Normandy.

\section{EXPLANATION OF PLATE 3}

Fig. 1. Ringsteadia pseudocordata (Blake and Hudleston), Westbury Ironstone, Pseudocordata. Subzone, Westbury, SMC J44984, $\times 0.7$. Fig. 2. Ringsteadia brandesi Salfeld, Marston Ironstone, Pseudoyo Subzone, Keypoint site, South Marston, SM19, ×0.6.

Fig. 3. Ringsteadia pseudocordata (Blake and Hudleston), Marston Ironstone, Pseudoyo Subzone, Keypoint site, South Marston, SM114, $\times 0.65$;

Fig. 4. Ringsteadia marstonensis Salfeld, Sandsfoot Grit, Pseudocordata Subzone, Sandsfoot Castle, DC119, $\times 1.0$.

Fig. 5. Ringsteadia bassettensis Spath, Westbury Ironstone, Pseudocordata Subzone, Westbury, SMC J44972, $\times 0.85$;

Fig. 6. Ringsteadia marstonensis, Marston Ironstone, Pseudoyo Subzone, Keypoint Site, South Marston, SM29, ×1.0.

All specimens septate inner whorls. Scale bars represent $10 \mathrm{~mm}$. No scale bar = natural size. 
PLATE 3
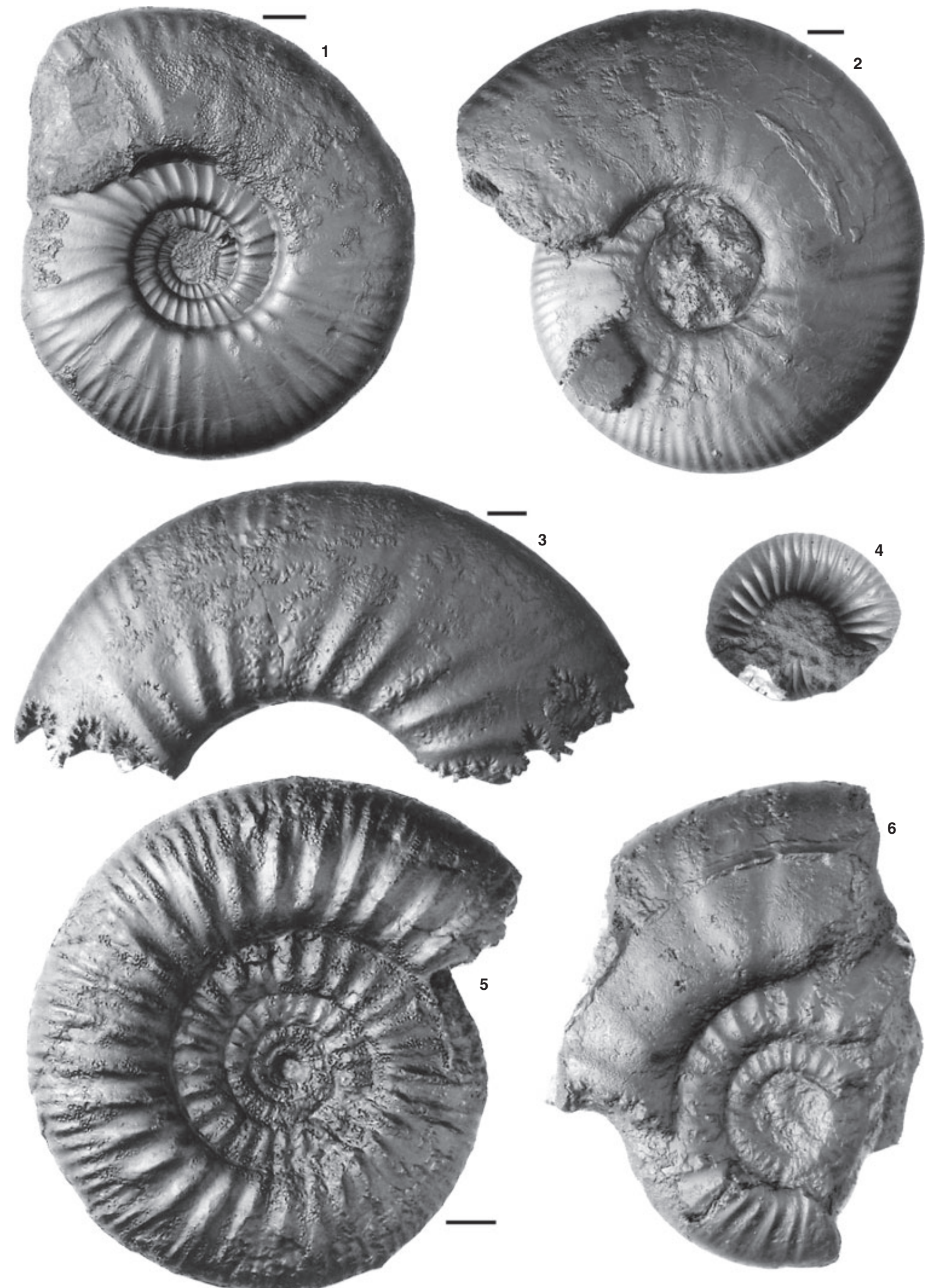
3. P. baylei horizon: identified at South Ferriby and defined in Normandy in the lower limestone of the Fm. des Calcaires coquilliers (bed B in Hantzpergue 1989, p. 54, fig. 12).

4. 'P. normandiana' horizon: Normandy, upper limestone of the Fm. des Calcaires coquilliers (bed D in Hantzpergue 1989). Some confusion attaches to the naming of this horizon. Firstly, it is not certain that the lectotype of $P$. normandiana Tornquist, 1896, came from this horizon, rather than from (3). Hantzpergue's claims to this effect must have been based on subsequently collected material and hence his interpretation of the species. If it did in fact come from (3), then $P$. normandiana morphosp. would be merely a variant of P. baylei biosp., as has at times been assumed in the past. Secondly, the name of the morphospecies was in fact regarded by Hantzpergue as a junior synonym of 'P.' thurmanni (Contejean, 1859), who therefore referred to horizon (4) as that of P. thurmanni. The type and sole known specimen of this species came from near Montbeliard (Doubs), eastern France, from beds immediately below a level with Pachypictonia indicatoria Schneidt (Amm. decipiens of Contejean: figured by Contini and Hantzpergue 1973). This strongly indicates the Cymodoce Zone.

5. ' $P$. aff. normandiana' horizon: East Greenland, Birkelund and Callomon (1985) fauna 14, with Amoeboceras bayi Birkelund and Callomon. A. bayi occurs in the highest Baylei Zone at Staffin in Skye (Matyja et al. 2006).

In morphospecific terms, the $P$. densicostata horizon as represented in the Inconstans Bed of south Dorset (89 specimens) is dominated by $P$. densicostata var. praebaylei nov. (47\%), with P. densicostata (19\%), P. densicostata var. dorsetensis nov. (10\%), P. seminudata (14\%) and $P$. seminudata var. ringsteadensis nov. (10\%).

\section{REPOSITORY OF SPECIMENS AND CONVENTIONS}

The following ammonite collections have been studied: Oxford University Museum (OUM); Sedgwick Museum, Cambridge
(SMC); Natural History Museum, London (NHM); Devizes Museum (D); British Geological Survey, Keyworth (BGS); Royal Holloway, University of London, comprising the former collections of Chelsea, Bedford and Kings Colleges (RHUL), plus the author's collection [DC, DK, SF and SM (now in BGS collection)]; University of Reading (UR), collection now housed at OUM; and the private collections of Professor J. H. Callomon (JHC), Mr Clive Griffiths (donated to NHM) and the late Mr Nick Samphier. One specimen loaned by York Museum (YORYM).

Several hundred ammonites have been examined in detail, and these are listed the Appendix. The collections of J. H. Callomon (Baylei Zone, Swindon), BGS (Pseudocordata/ Baylei Zones, A303) and N. Samphier (Pseudocordata/Baylei Zones, Ringstead) have only been assessed in general terms.

Ammonite measurements: whorl height, umbilical width and whorl breadth are given conventionally as proportions of the shell diameter at which the measurements were made.

The following abbreviations are used:

$\mathrm{D}$ (phg), diameter at final septum; $\mathrm{D}$ (phg-ad), diameter of adult with uncoiling and/or crowding of final septae; $\mathrm{D}$ (phg-juv), juvenile; $\mathrm{D}(\max )$, maximum diameter preserved; $0 . \mathrm{x}$ wh bch, fraction of body chamber preserved as a proportion of the whorl; rpw, ribs per whorl.

The principal illustrations of the specimens are in Plates 110. Drawings of cross-sections of species of Ringsteadia are given in Text-figures 5 and 6, drawings of typical sutures of Ringsteadia and Pictonia are given in Text-figure 7, and plots of whorl height against umbilical diameter are given in Textfigure 8 .

\section{SYSTEMATIC PALAEONTOLOGY}

\author{
Superfamily PERISPHINCTOIDEA Steinmann, 1890 \\ Family AULACOSTEPHANIDAE Spath, 1924
}

As a preliminary to the descriptions below, a brief survey is presented of all existing nominal aulacostephanid genera that have been used for British Sub-Boreal Pseudocordata Zone and Baylei Zone material, but that are not used in the present work. A correlation of the Sub-Boreal and Sub-Mediterranean zones and subzones referred to is given in Text-figure 4.

\section{EXPLANATION OF PLATE 4}

Figs 1-2. Ringsteadia bassettensis Spath var. strattonensis nov.; 1, specimen SM190, $\times 0.7 ; 2$, specimen SM60, $\times 0.85$. Each outer whorl is body chamber.

Fig. 3. Ringsteadia marstonensis Salfeld, SM115, $\times 0.4$.

Figs 4-5. Ringsteadia bassettensis Spath; 4, specimen SM129, $\times 1.0$; 5 , specimen SM144, $\times 1.0$.

Fig. 6. Microbiplices anglicus Arkell, Sandsfoot Grit, Pseudocordata Subzone, Sandsfoot Grit, Sandsfoot Castle, ic377, $\times 1.0$.

All specimens except 6 from the Marston Ironstone, Pseudoyo Subzone, at the Keypoint site, South Marston. Scale bars represent $10 \mathrm{~mm}$. No scale bar = natural size. 
PLATE 4

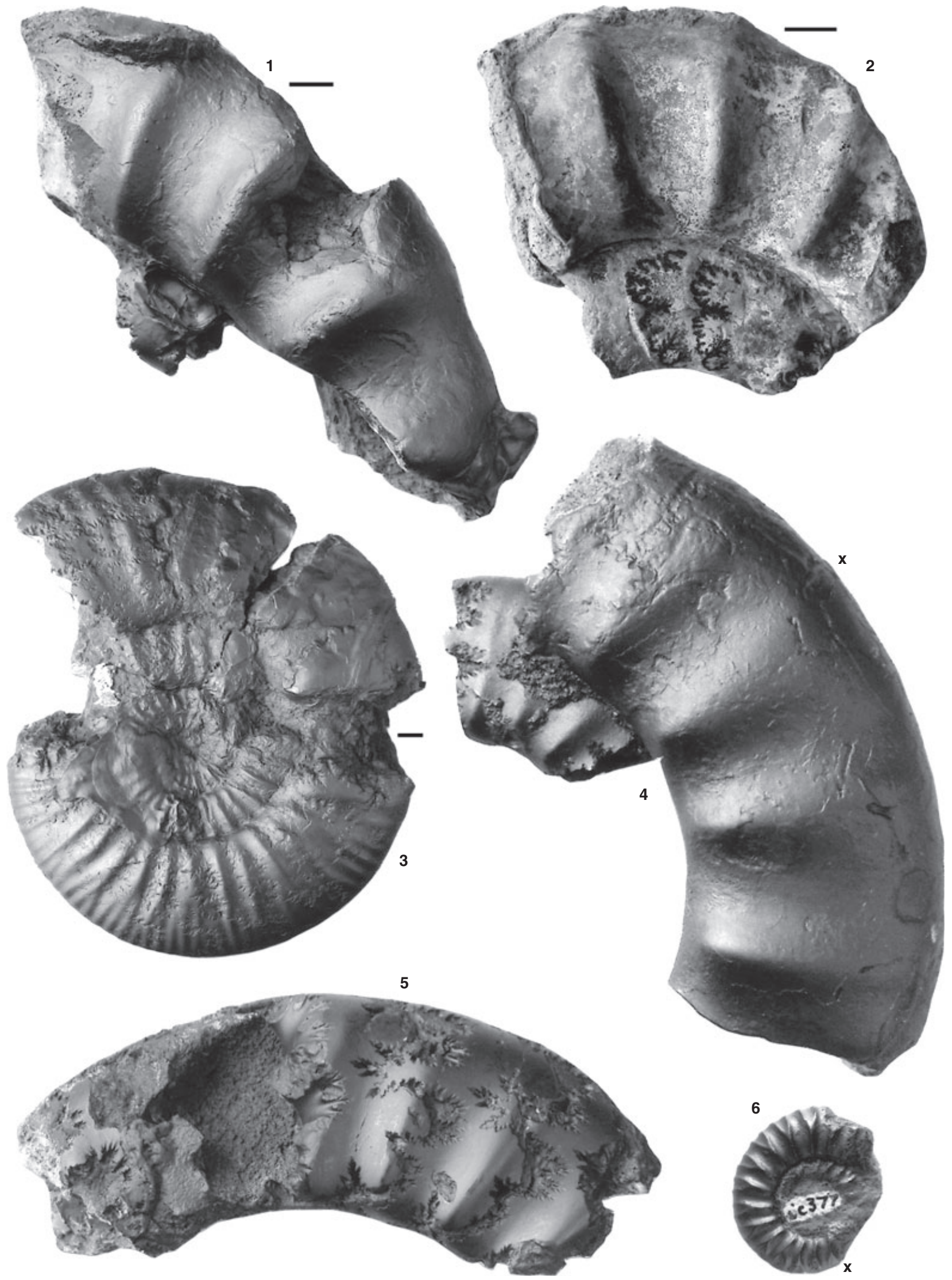

WRIGHT, Microbiplices, Ringsteadia 
Balticeras Dohm (1925, p. 34)

Type species. Balticeras pommerania Dohm, 1925 (pl. 5, figs 13), from the Upper Jurassic of Zarnglaff, Pomerania (now Czarnogłowy, western Poland). Dohm inadvertently also used Baltia in his text, but the intention clearly was to name the genus Balticeras.

Dohm (1925) introduced the name for smooth-shelled, involute to moderately involute, discoidal ammonites collected from the incomplete, shelly, Oxfordian/Kimmeridgian succession of shallow water platform carbonates in the Zarnglaff quarries. There was little stratigraphical control over the collection of the specimens, and their age, Late Oxfordian or Early Kimmeridgian, is unclear. Dohm (1925) included two quite separate forms under the one name. B. ramlowi Dohm has a marked uncoiling of the umbilical seam, with the outermost whorl only just in contact with the preceding whorl. The extremely involute B. pommerania Dohm has an unusual suture with a markedly oblique second lateral lobe. Use of Balticeras as a subgenus for involute morphospecies of Ringsteadia, following Arkell et al. (1957), is not recommended.

Pomerania Arkell (1937, p. 69)

Type species. By original designation Pomerania dohmi Arkell, 1937 (p. 69), nom. nov. for Pictonia baylei Dohm non Salfeld (Dohm, 1925, p. 32, pl. 5, fig. 6), from the Upper Jurassic of Zarnglaff, Pomerania (now Czarnogłowy, western Poland). The age of Pomerania is probably also Early Kimmeridgian.

The type species has 20-25 ribs per whorl from an early diameter. It is certainly an aulacostephanid, but the prominent primary ribbing suggests it is close to Rasenia. Pomerania was used in this sense for Early Kimmeridgian raseniids from the Polish Holy Cross Mountains by Kutek (1968). By contrast, forms like P. schmidti (Dohm) are more densely ribbed on the inner whorls, with bold, coarse ribbing on the body chamber, which exceeds $500 \mathrm{~mm}$ in diameter. They may be perisphinctinids.

Arkell (1937) included in his diagnosis fragmentary macroconch perisphinctoid body chambers collected from the Upper Oxfordian Cautisnigrae Zone in Cambridgeshire. Arkell believed that the inner whorls of such specimens resembled Decipia. Wright (1996) showed that the inner whorls of Arkell's morphotypes were of the normal, biplicate, perisphinctoid type and named this taxon Pseudopomerania. Thus, Arkell's (1947a) use of Pomerania as a subgenus of Decipia is not followed here. Pseudocordata Zone forms, which Arkell assigned to Pomerania are here regarded as coarsely ribbed, evolute varieties of Ringsteadia.
Pachypictonia Schneid (1940, p. 89)

Type species. Pictonia indicatoria Schneid, 1940 (pl. 4, figs 1-4), from the Malm Gamma 2 (Hypselocyclum Zone; ?=Mutabilis Zone) of Zeegendorf in the Franconian Alb.

Schneid's figures clearly show a coarsely ribbed macroconch raseniid, with bold, prorsiradiate primary ribs on the inner whorls. Pachypictonia is, in fact, a further member of the separate, Early Kimmeridgian Jura-Pomeranian endemic group that includes also Pomerania and Balticeras. The use of Pachypictonia by Arkell (1948) for a coarsely ribbed variant of Late Oxfordian Ringsteadia having almost smooth inner whorls was inappropriate and is not adopted here.

\section{Triozites Buckman (1924a, pl. 494)}

Type species. Triozites seminudatus Buckman, 1924a (pl. 494), in the distinctive matrix of the Inconstans Bed, Baylei Zone, of Ringstead Bay, Dorset.

The affinities of Triozites are certainly with Pictonia. The suture is the same, with the lateral lobe slightly longer than the suspensive lobe, the development of a second lateral and three small elements in the suspensive lobe. The presence of half a whorl of smooth phragmocone prior to the smooth body chamber is again very characteristic of Pictonia, as are the rectiradiate, rod-like primaries, although these occasionally may have a slight ' $S$ ' curve, anticipating the rib style of Rasenia. However, no marked constrictions or flared ribs are visible on the inner whorls. T. seminudatus is thus used here, as Pictonia seminudata, for nonconstricted varieties of Pictonia.

\section{Genus RINGSTEADIA Salfeld, 1913}

Type species. Ammonites pseudocordatus Blake and Hudleston, 1877 (p. 392, pl. xiii, fig. 1) by original designation of Salfeld (1913, p. 427 and 1914, p. 129) from the Pseudocordata Subzone Westbury Ironstone of Westbury, Wiltshire. Holotype refigured by Buckman (1925a, pl. 560A, 560B).

Remarks. Ringsteadia comprises an extremely variable group of large Late Oxfordian aulacostephanids (extending

\section{EXPLANATION OF PLATE 5}

Fig. 1. Ringsteadia anglica Salfeld, UR 10895. ×0.65, Westbury Ironstone, Pseudocordata Subzone, Westbury;

Fig. 2. Ringsteadia pseudoyo Salfeld, Marston Ironstone, Pseudoyo Subzone, Keypoint site, Swindon, SM262, $\times 0.9$;

Fig. 3. Ringsteadia pseudoyo Salfeld, Osmington Mills Ironstone, Evoluta Subzone, Ringstead Bay, OUM J21186, $\times 0.85$.

Figs 4-5. Pictonia seminudata (Buckman), Inconstans Bed, Baylei Zone, Ringstead Bay: 4, OUM J67169, ×0.55; 5, OUM J13337, ×0.6. Specimens figured in 1-3 septate inner whorls; 5, outer whorl is body chamber. Scale bars represent $10 \mathrm{~mm}$. 
PLATE 5
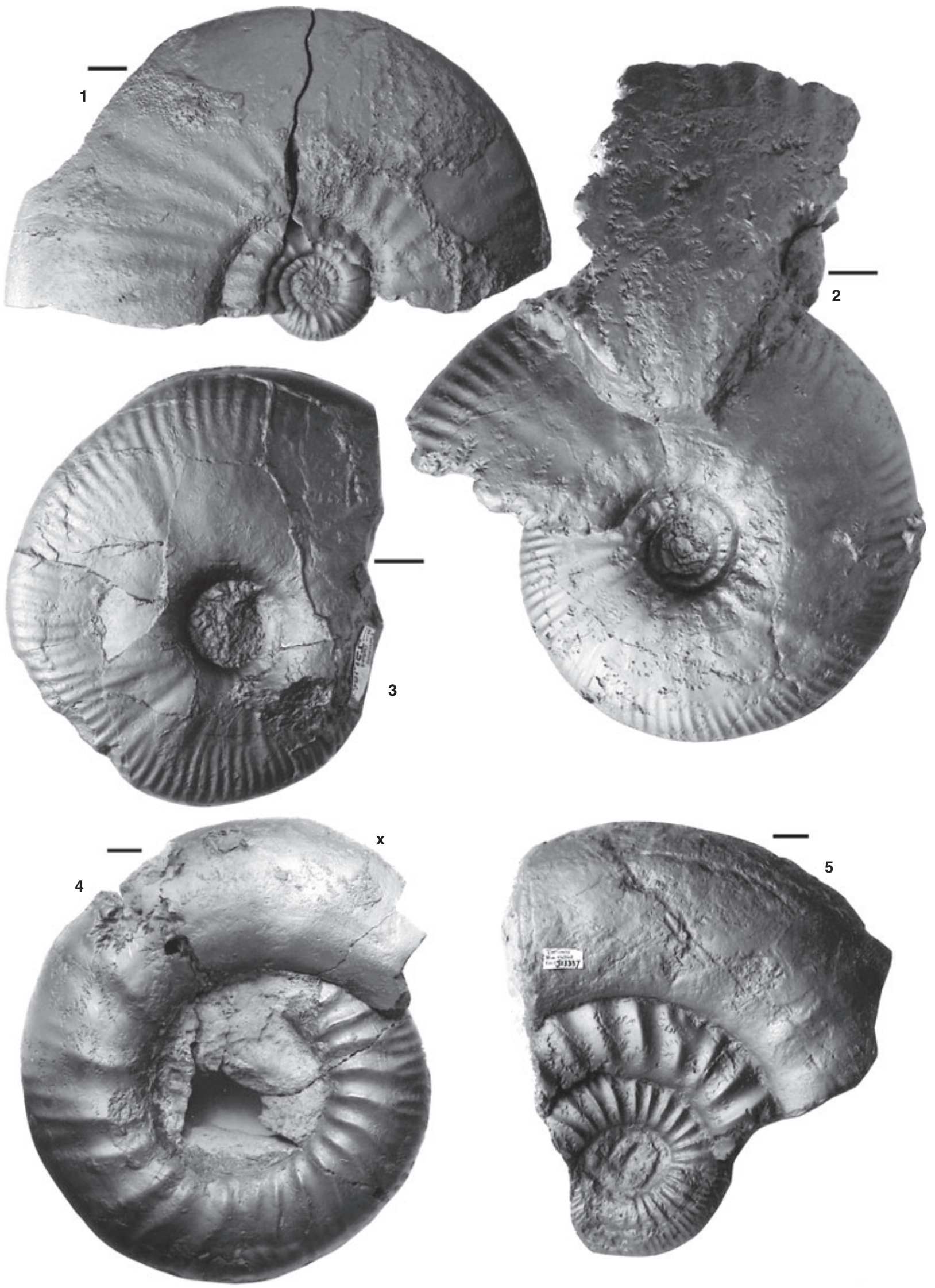

WRIGHT, Pictonia, Ringsteadia 


\begin{tabular}{|c|c|c|c|c|c|c|}
\hline \multirow{2}{*}{\begin{tabular}{|l|}
$\underline{w}$ \\
0 \\
5 \\
\\
\end{tabular}} & \multicolumn{2}{|c|}{ Boreal } & \multicolumn{2}{|c|}{ Sub-Boreal } & \multicolumn{2}{|c|}{ Sub-Mediterranean } \\
\hline & zone & subzone & Zone & subzone & zone & subzone \\
\hline \multirow{8}{*}{ 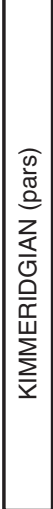 } & \multirow{4}{*}{ Kitchini } & \multirow{2}{*}{ Modestum } & Mutabilis (pars) & & $\begin{array}{l}\text { Hypselocyclum } \\
\text { (pars) }\end{array}$ & Lothari \\
\hline & & & \multirow{3}{*}{ Cymodoce } & & \multirow{3}{*}{ Platynota } & Guilherandense \\
\hline & & \multirow{2}{*}{ Subkitchini } & & & & Desmoides \\
\hline & & & & & & Polygyratus \\
\hline & \multirow{4}{*}{ Bauhini } & & \multirow{4}{*}{ Baylei } & Normandiana & \multirow{2}{*}{ Planula } & Galar \\
\hline & & & & & & Planula \\
\hline & & & & \multirow{2}{*}{ Densicostata } & \multirow{4}{*}{ Bimammatum } & Hauffianum \\
\hline & & & & & & Bimammatum \\
\hline \multirow{7}{*}{ 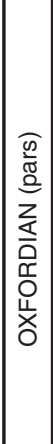 } & \multirow{3}{*}{ Rosenkrantzi } & \multirow{2}{*}{ Rosenkrantzi } & \multirow{4}{*}{ Pseudocordata } & Evoluta & & \multirow{2}{*}{ Hypselum } \\
\hline & & & & Pseudocordata & & \\
\hline & & Marstonense & & Pseudoyo & \multirow{3}{*}{ Bifurcatus } & \\
\hline & Regulare & & & Caledonica & & Grossouvrei \\
\hline & Serratum & $\begin{array}{c}\text { Serratum } \\
\text { Koldewevense }\end{array}$ & \multirow{2}{*}{ Cautisnigrae } & Variocostatus & & Stenocycloides \\
\hline & \multirow{2}{*}{ Glosense } & Glosense & & Cautisnigrae & \multirow{2}{*}{$\begin{array}{l}\text { Transversarium } \\
\text { (pars) }\end{array}$} & Rotoides \\
\hline & & Ilovaiskii & & Nunningtonense & & Schilli \\
\hline
\end{tabular}

TEXT-FIG. 4. Zonal and subzonal scheme for part of the Upper Jurassic sequence in the Boreal and Sub-Boreal Provinces, and the correlation with that for the Sub-Mediterranean province, after Matyja and Wierzbowski (1997, fig. 4), Wright (2003, fig. 11) and Matyja et al. (2006).

into the Early Kimmeridgian in the Sub-Mediterranean Province), maximum diameter up to $400 \mathrm{~mm}$, shell shape ranging from strongly involute, discoidal to evolute, planulate. In the early whorls, the whorl section is invariably rounded, but between 30 and $50 \mathrm{~mm}$ diameter this changes either to a flattened oval or to rounded-triangular. The whorl breadth/whorl height ratio thus varies from 0.45 to 1.20 . Some forms are smooth, but most have rounded primary ribbing fading gradually towards the end of the phragmocone, with the secondaries arising irregularly from the primaries often in sheaves of three or more. Strong constrictions may be present, three or four per whorl, and in late forms these may be followed by a swollen simple rib. The variably complex suture comprises external and lateral lobes, a second lateral lobe, and a separate, well-developed suspensive lobe with six distinctive elements.

Salfeld (1917) recognised seven species of Ringsteadia, providing detailed descriptions and illustrations. Buckman (1926) and Spath (1935) each added a further species to this list. These morphospecies have overlapping ranges and will therefore co-occur to varying degrees at any one stratigraphical level. When they do, it has become clear that at such a level they represent merely the intergrading variants of a single biospecies. However, it is useful to continue the use of morphospecific names in order to facilitate description of the genus, for the range of variation in morphology in Ringsteadia is so great.

\section{EXPLANATION OF PLATE 6}

Figs 1, 4-5. Ringsteadia frequens Salfeld, Osmington Mills Ironstone. Evoluta Subzone; 1, Black Head, JHC 933, ×1.0; 4, 5, Ringstead Bay; 4, SMC J44958, ×0.85; 5, SMC J44959, ×0.6.

Fig. 2. Pictonia seminudata (Buckman), var. ringsteadensis nov. Inconstans Bed, Baylei Zone, Ringstead Bay, DK11, $\times 0.55$.

Figs 3, 6. Ringsteadia evoluta Salfeld, Osmington Mills Ironstone, Evoluta Subzone; 3, Black Head, DC139, ×1.0; 6, Ringstead Bay, DC125, $\times 1.0$.

Specimens figured in 1-4, 6 are septate inner whorls. Scale bars represent $10 \mathrm{~mm}$. No scale bar = natural size. 
PLATE 6
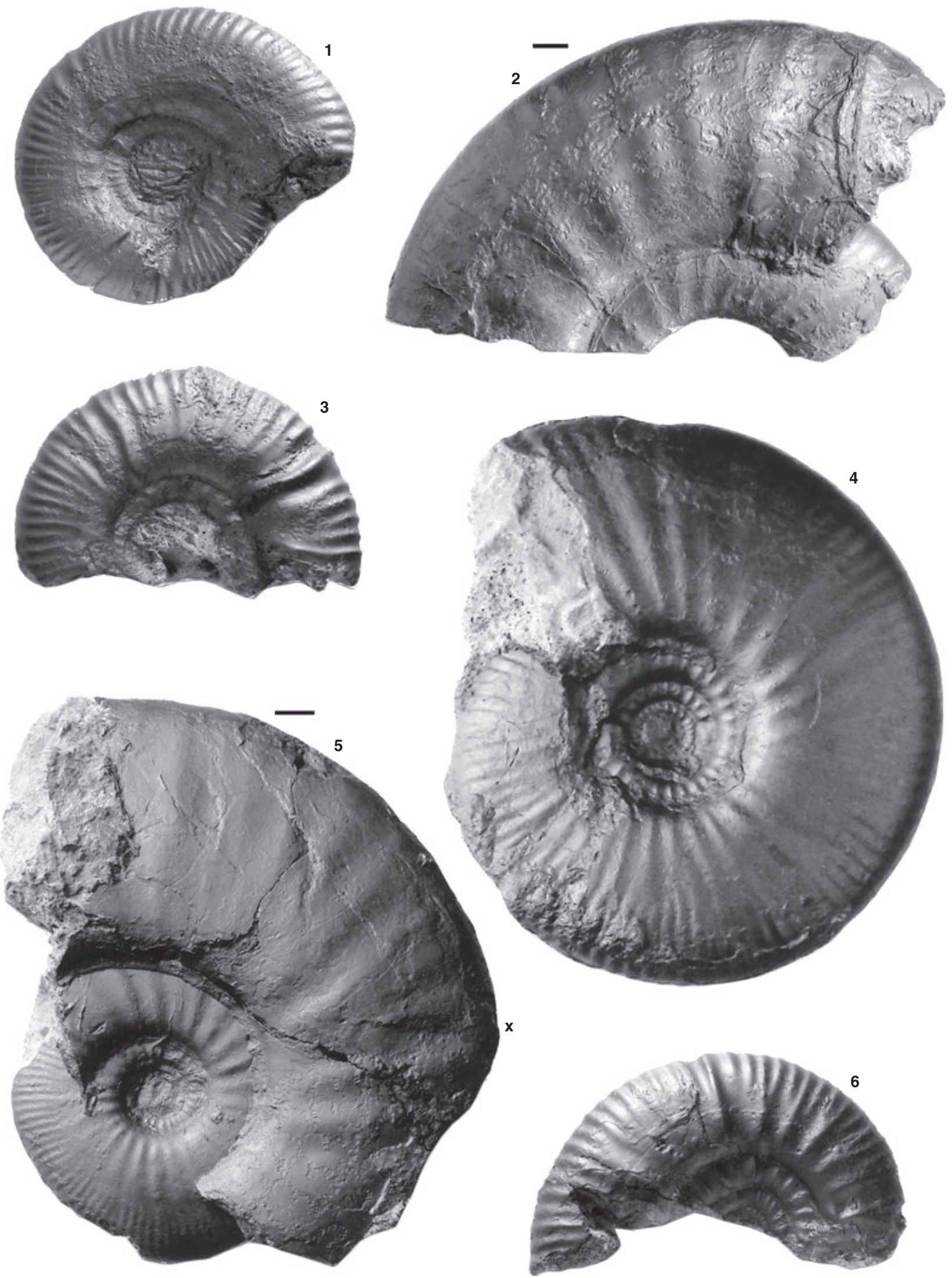

WRIGHT, Pictonia, Ringsteadia 
Attempts to subdivide Ringsteadia into subgenera (i.e. as in Arkell et al. 1957) bring nothing new to the taxonomic problems and serve only to complicate those of nomenclature. In place of a subgeneric classification, simple groupings based on typical morphospecies are preferred here. Text-figure $8 \mathrm{~A}$ shows three major groupings within the spread of involute to evolute forms in the Pseudoyo Subzone. These can conveniently be referred to as three groups: (1), R. pseudoyo; (2), R. brandesi and (3), $R$. marstonensis groups. Within each grouping, morphospecies have been recognised by previous workers on the basis of differing whorl breadth or by differing strength of ribbing. In the Pseudocordata Subzone (Text-fig. 8B), these three groups are still recognized, but with a preponderance of moderately evolute and evolute forms. In the Evoluta Subzone (Text-fig. 8C), the spread from involute to evolute forms is less, and there is less variation in strength of ribbing, so that only four morphospecific names have been used, $R$. pseudoyo, $R$. frequens, $R$. evoluta and $R$. marstonensis. In what follows, the morphospecies of Ringsteadia in groups 1-3 are described in order of increasing evoluteness, followed by the descriptions of $R$. frequens and $R$ evoluta.

\section{Ringsteadia pseudoyo group}

Ringsteadia pseudoyo Salfeld, 1917

Plate 1, figures 1, 3; Plate 5, figures 2, 3; Plate 7, figure 4; Text-figures $5 A-B, E, 7 B, I$

1917 Ringsteadia pseudo-yo Salfeld, p. 74, pl. 8, figs $1 \mathrm{a}-\mathrm{b}, 2 \mathrm{a}-\mathrm{b}$.

?1978 Ringsteadia sp.; Rozak and Brochwicz-Lewinski, pl. 4 , fig. 3a-b.

2003 Ringsteadia pseudoyo Salfeld; Wright, fig. 9f.

2006 Ringsteadia ex. gr. pseudoyo Salfeld; Matyja et al., fig $4 \mathrm{~b}$.
Type material. Two syntypes; lectotype (NHM 24089, Marston Ironstone, Wootton Bassett), Salfeld, 1917, pl. 8, fig. 1a-b, designated by Buckman, 1926, pl. 672; paratype (NHM 36960, Marston Ironstone, South Marston).

Measurements. Lectotype: $\mathrm{D}(\max ) 133 \mathrm{~mm}$; at $133 \mathrm{~mm}, 0.47$, 0.22, 0.17. BGS Zm2295: $\mathrm{D}(\max ) 109 \mathrm{~mm}$; at $109 \mathrm{~mm}, 0.43$, $0.25,0.22$. OUM J14616 (figured Wright, 2003, fig. 9f): D( $\max )$ $114 \mathrm{~mm}$; at $114 \mathrm{~mm}, 0.48,0.26,0.17,25$ ribs. OUM J14822: $\mathrm{D}$ (phg-ad) $175 \mathrm{~mm}$; at $175 \mathrm{~mm}, 0.47,0.23,0.22 ; 0.1$ wh. bc. OUM J21186 (Pl. 5, fig. 3): $\mathrm{D}(\max ) 92 \mathrm{~mm}$; at $92 \mathrm{~mm}$; 0.49 , $0.29,0.20$. OUM J37527: $\mathrm{D}(\max ) 91 \mathrm{~mm}$; at $91 \mathrm{~mm}, 0.46,0.26$, 0.22. SM192 (Pl. 1, fig. 3): D(phg-?ad) $147 \mathrm{~mm}$; at $147 \mathrm{~mm}$, $0.49,0.23,0.15$. SM228 (Pl. 1, fig. 1): $\mathrm{D}(\max ) 115 \mathrm{~mm}$; at $96 \mathrm{~mm}, 0.49,0.26,0.16$. SM262 (Pl. 5, fig. 2): D(phg-?ad) $165 \mathrm{~mm}$; at $102 \mathrm{~mm}, 0.46,0.26,0.19$; at $155 \mathrm{~mm}, 0.47,0.24$, 0.24 .

Description. This slim, discus-like form has an umbilical width varying from 15 per cent to 22.5 per cent of the diameter (Textfig. 8A). On the inner whorls (Pl. 1, fig. 1; Pl. 5, fig. 2), the primary ribbing is fine and prorsiradiate, with strong constrictions. Above $20 \mathrm{~mm}$, constrictions cease. The primaries are gently raised and slightly prorsiradiate, and broaden and pass into a sheaf of 3 or 4 secondaries carrying on the same prorsiradiate trend (Pl. 5, fig. 2). Above $90 \mathrm{~mm}$, a smooth spiral band separates primaries and secondaries (Pl. 1, fig. 1). The secondaries fade as they cross the venter. Some specimens are almost completely smooth at $75 \mathrm{~mm}$ (Pl. 1, fig. 3). The whorl section is rounded/triangular, being broadest just above the umbilical margin, and the sides sloping to meet the acutely rounded venter (Text-fig. 5A-B).

In specimens from the Ringstead Coral Bed (Pl. 5, fig. 3; Pl. 7, fig. 4), the umbilicus varies from 20 per cent to 23 per cent of the diameter. Moderately strong, well-spaced primaries and secondaries are developed at $35 \mathrm{~mm}$ (Pl. 7, fig. 4). Constrictions interrupt the rib pattern, but frequently sheaves of three secondaries arise from primaries. The primary ribs fade earlier than the strongly developed secondaries. There is a subtle angle between the slightly prorsiradiate primaries and rectiradiate

\section{EXPLANATION OF PLATE 7}

Fig. 1. Ringsteadia frequens Salfeld, Osmington Mills Ironstone, Evoluta Subzone, ?Ringstead Bay, OUM J13104, ×0.6.

Fig. 2. Pictonia densicostata Buckman, var. praebaylei nov., type of var., Inconstans Bed, Baylei Zone, Ringstead Bay, SMC J47870, $\times 0.5$.

Fig. 3. Ringsteadia evoluta Salfeld, largely complete juvenile macroconch, Osmington Mills Ironstone, Evoluta Subzone, Osmington Mills, JHC 936, $\times 1.0$.

Fig. 4. Ringsteadia pseudoyo Salfeld, Osmington Mills Ironstone, Evoluta Subzone, Ringstead Bay, OUM J37757, $\times 0.85$.

Figs 5-6. Pictonia densicostata Buckman, var. dorsetensis nov. Inconstans Bed, Baylei Zone, Ringstead Bay, DK6, ×1.0.

Fig. 7. Ringsteadia frequens Salfeld, Osmington Mills Ironstone, Evoluta Subzone, Ringstead Bay, DC141, $\times 0.75$.

Fig. 8. Prorasenia sp.,, Osmington Mills Ironstone, Evoluta Subzone, East Fleet section, NHM C75302, ×1.0.

Fig. 9. Prorasenia bowerbanki Spath, Kimmeridge Clay, Oxytoma Cementstone, Baylei Zone, South Ferriby Clay Pit, SF1, $\times 1.0$.

Specimens figured in 4-6 are septate inner whorls; 8 is a partially complete, microconch adult with the test preserved, showing uncoiling of the umbilical seam; 9 is a complete, microconch adult with lappets, and much of the test preserved. Scale bars $=10 \mathrm{~mm}$. No scale bar $=$ natural size. 
PLATE 7
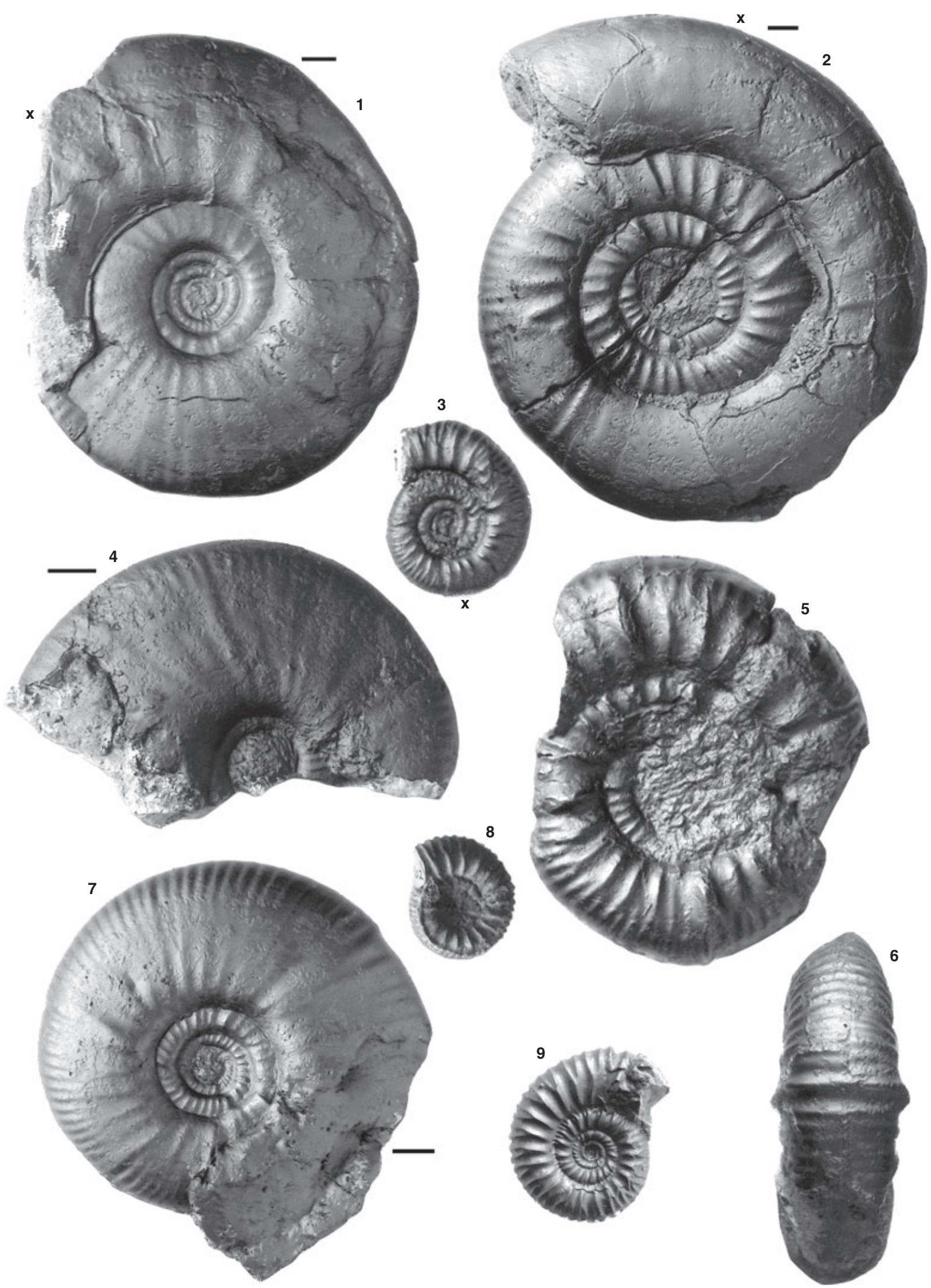

WRIGHT, Pictonia, Prorasenia, Ringsteadia 
secondaries. These then have a distinct forward swing at the ventro-lateral edge, giving a slight $\mathrm{S}$-shaped curve to the ribbing.

Stratigraphical range. These markedly involute forms of Ringsteadia are moderately common in the Marston Ironstone (Pseudoyo Subzone) of South Marston. R. pseudoyo is rare in the Pseudocordata Subzone and also occurs sporadically in the south Dorset Evoluta Subzone.

Remarks. The Evoluta Subzone forms of R. pseudoyo are not quite as involute as those in the Pseudoyo Subzone, with a whorl section having the sides more nearly parallel than in the early $R$. pseudoyo. A specimen close to R. pseudoyo, involute, with early fading of the primaries and dense secondaries, was figured from the lower Hypselum Subzone (mid-Pseudocordata Zone) of Czestochowa in Poland by Rozak and Brochwicz-Lewinski (1978).

\section{Ringsteadia sphenoidea Buckman, 1926 Plate 2, figure 9; Text-figure $5 \mathrm{C}$}

1926 Ringsteadia sphenoidea Buckman, pl. 672.

Type material. Holotype (NHM C41691) from the Marston Ironstone of Wootton Bassett.

Measurements. Holotype: $\mathrm{D}(\max ) 180 \mathrm{~mm}$; at $170 \mathrm{~mm}, 0.48$, 0.27 , 0.16. SM96 (Pl. 2, fig. 9): $\mathrm{D}(\max ) 165 \mathrm{~mm}$; at $162 \mathrm{~mm}$, $0.48,0.30,0.18$.

Description. Comparison of Plate 2, figure 9 with the specimen figured as $R$. pseudoyo in Plate 1, figure 3 shows that $R$. sphenoidea is just as involute as $R$. pseudoyo but is distinguished by its much broader, triangular whorl section (Text-fig. 5C). The specimen figured matches Buckman's holotype perfectly, and this is a distinctive and easily recognised morphospecies.

Stratigraphical range. R. sphenoidea is a moderately common form in the Pseudoyo Subzone of South Marston. It is not known in the Pseudocordata or Evoluta subzones.
2. Ringsteadia brandesi group

Ringsteadia brandesi Salfeld, 1917

Plate 1, figure 2; Plate 2, figures 2-6; Plate 3, figure 2; Textfigures $5 D, G-H, 7 C-F$, J

1917 Ringsteadia brandesi Salfeld, p. 77, pl. 9, fig. 1a-b, pl. 10, fig. 3a-b.

non 1917 Ringsteadia brandesi Salfeld, pl. 11, fig. 3a-b.

?1917 Ringsteadia brandesi Salfeld, p. 78.

2007 Ringsteadia cf. anglica Buckman; Rogov and Kiselev, pl. 4, figs 1-2.

Type material. Two syntypes from the Marston Ironstone; lectotype now designated; Salfeld, 1917, pl. 9, fig. 1a-b, NHM 50770, from South Marston; paratype NHM 15425 from Wootton Bassett.

Measurements. Lectotype: $\mathrm{D}(\max ) 138 \mathrm{~mm}$; at $138 \mathrm{~mm}, 0.42$, $0.26,0.26$. BGS GSM7717: $\mathrm{D}(\max ) 138 \mathrm{~mm}$; at $138 \mathrm{~mm}, 0.42$, $0.21,0.23$. BGS HBW2644: $\mathrm{D}$ (phg-ad) $258 \mathrm{~mm}, \mathrm{D}(\max )$ $275 \mathrm{~mm}$, at $167 \mathrm{~mm}, 0.42,0.23,0.29$. SM19 (Pl. 3, fig. 2): $\mathrm{D}(\max ) 145 \mathrm{~mm}$; at $145 \mathrm{~mm}, 0.42,0.27,0.29$. SM138 (Pl. 2, fig. 2): $\mathrm{D}(\max )$ c. $160 \mathrm{~mm}$; at $82 \mathrm{~mm}, 0.42,0.30,0.31,19$ ribs. SM229 (Pl. 1, fig. 2): (D(phg-?ad) $151 \mathrm{~mm}$; at $149 \mathrm{~mm}, 0.41$, $0.24,0.26$. YORYM:2004.179 (Pl. 2, fig. 3): $\mathrm{D}(\max ) 99 \mathrm{~mm}$; at $99 \mathrm{~mm}, 0.43,0.31,0.26$.

Description. R. brandesi has the umbilical width varying from 23 per cent to 31 per cent of the total diameter. The early primary ribs are broadly rounded and slightly prorsiradiate. On coarser ribbed forms (Pl. 2, fig. 2), the secondaries bifurcate or trifurcate just below the mid-point of the whorl side, continuing along the line of the primaries and curving forwards slightly over the venter. On finer ribbed forms (Pl. 2, fig. 3; Pl. 3, fig. 2), the primaries pass indistinctly into sheaves of three secondaries. At $70 \mathrm{~mm}$ diameter, the primary ribs begin to fade, although the secondaries continue more prominently. Above $110 \mathrm{~mm}$, almost all forms are smooth, although one specimen has well-developed ribbing at $180 \mathrm{~mm}$. At $40 \mathrm{~mm}$ diameter, the whorl breadth is equal to the whorl height, but thereafter a slim whorl section develops, with the maximum breadth being at a quarter or a third of the whorl height (Text-fig. 5D, G-H).

\section{EXPLANATION OF PLATE 8}

Fig. 1. Ringsteadia frequens Salfeld, Osmington Mills Ironstone, Osmington Mills, Evoluta Subzone, NHM C93796, $\times 0.85$.

Fig. 2. Pictonia seminudata (Buckman), Inconstans Bed, Ringstead Bay, OUM J29499, ×1.0.

Figs 3-5. Ringsteadia evoluta Salfeld, Osmington Mills Ironstone, Evoluta Subzone; 3, 4, Black Head; 3, JHC 931, ×0.7; 4, JHC 932, $\times 0.8 ; 5$, Osmington Mills, DC122, $\times 0.75$.

Fig. 6. Pictonia densicostata Buckman, largely complete juvenile macroconch, Inconstans Bed, Baylei Zone, Ringstead Bay, DK9, $\times 1.0$.

Figs 7-8. Prorasenia cf. hardyi Spath, Inconstans Bed, Baylei Zone, Ringstead Bay, ×1.0: 7, DK10; 8, DK34.

Specimens figured in 1, 3 and 7 are septate inner whorls; 2 is a nearly complete juvenile macroconch. Scale bars represent $10 \mathrm{~mm}$. No scale bar = natural size. 
PLATE 8
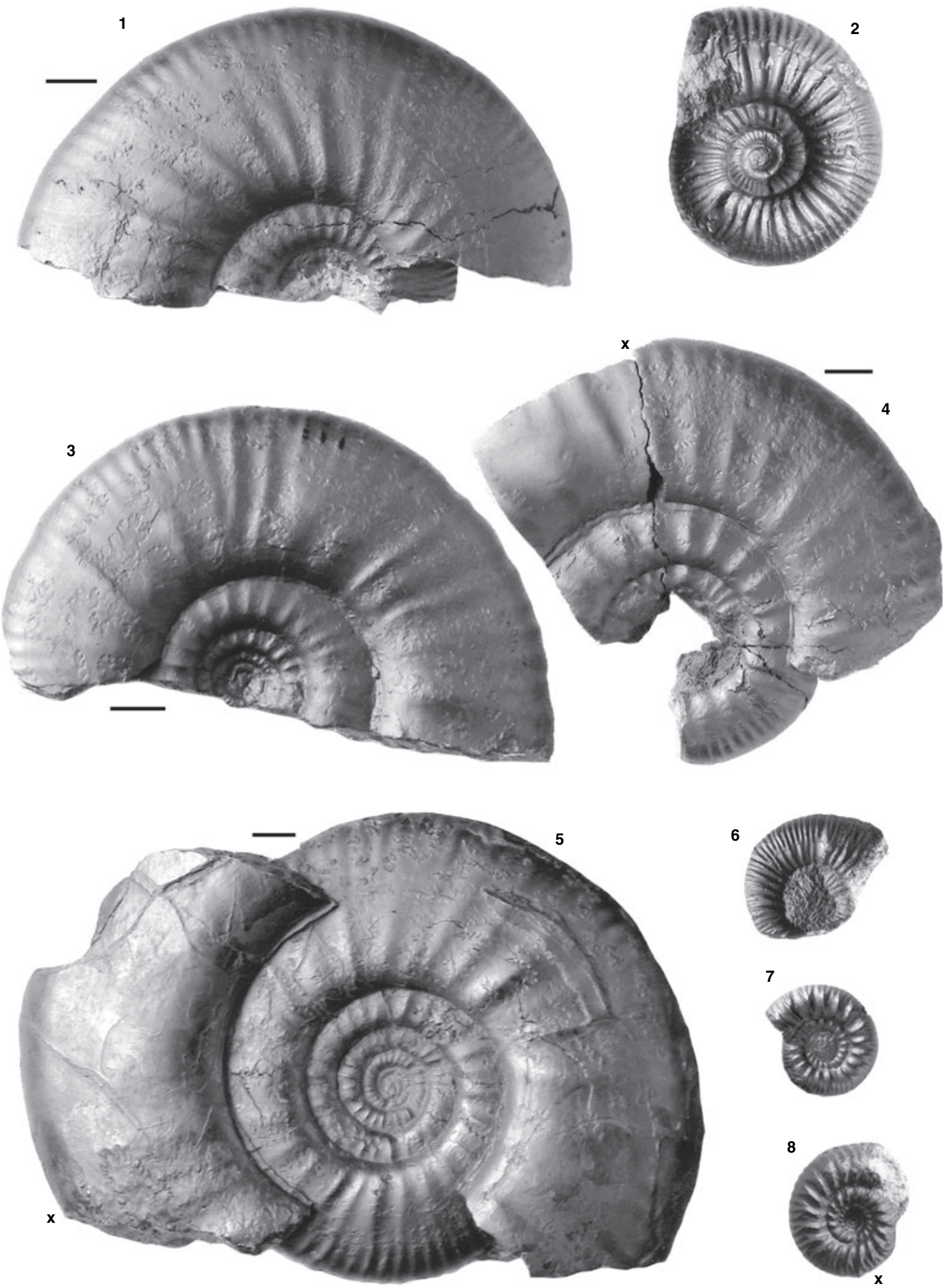

WRIGHT, Pictonia, Prorasenia, Ringsteadia 
Stratigraphical range. $R$. brandesi is one of the most common morphospecies in the Pseudoyo Subzone. It is less frequent in the Pseudocordata Subzone, and in the Evoluta Subzone its place as a moderately involute species of Ringsteadia is taken by $R$. frequens.

Remarks. The name R. brandesi has previously been applied to Evoluta Subzone Ringsteadia. However, careful study of the lectotype and paratype shows that both came from the Marston Ironstone, and are thus from the Pseudoyo Subzone. A third specimen described as R. brandesi came from the Osmington Mills Ironstone (Salfeld, 1917, pl. 11, fig. 3a, b) and is regarded here as $R$. frequens. The differences between $R$. brandesi and $R$. frequens are discussed under $R$. frequens below. Three specimens of $R$. brandesi are recorded from the Upper Korallenoolith of the Hannover region (Galgenberg, Salzhemmendorf) by Salfeld (1917). A specimen very close to R. brandesi, from Trzebinia, southern Poland, and described originally as Proplanulites teisseyrei Siemiradzki (Siemiradzki 1891), is in the Siemiradzki Collection in Krakow (Głowniak and Wierzbowski 2007). One specimen of $R$. brandesi was figured by Rogov and Kiselev (2007) from the Upper Oxfordian of Mikhalenino, Unzha River Basin, North-east of Moscow.

\section{Ringsteadia anglica Salfeld, 1917}

Plate 2, figure 1; Plate 5, figure 1; Text-figure 5F

1917 Ringsteadia anglica Salfeld, p. 76, pl. 8, fig. 3a-b, pl. 10, fig. 2a-b, pl. 13, fig. 1 .

1921 Ringsteadia anglica Salfeld; Buckman, pl. 225.

non 1933 Ringsteadia anglica Salfeld; Arkell, pl. 38, fig. 1.

non 2007 Ringsteadia cf. anglica Buckman; Rogov and Kiselev, pl. 4, figs 1-2.

Type material. Three syntypes; lectotype now formally designated (Salfeld 1917, pl. 13, fig. 1, BGS GSM25502, from the Westbury Ironstone); paratypes NHM C50768 from the Ampthill Clay (?Marston Ironstone) of Shrivenham and NHM C322 ('Wiltshire').

Measurements. BGS GSM97551: $\mathrm{D}(\max ) 172 \mathrm{~mm}$; at $172 \mathrm{~mm}$, $0.30,0.20,0.44,32$ ribs.
NHM C50768: $\mathrm{D}(\max ) 135 \mathrm{~mm}$; at $105 \mathrm{~mm}, 0.43,0.28,0.29$. SM135 (Pl. 2, fig. 1): D(max) $157 \mathrm{~mm}$; at $129 \mathrm{~mm}, 0.41,0.20$, 0.27 . UR 10895 (Pl. 5, fig. 1): $\mathrm{D}(\max ) 148 \mathrm{~mm}$; at $148 \mathrm{~mm}$, $0.40,0.20,0.28$.

Description. R. anglica is a slim, discoidal, moderately evolute form, with the umbilical margin scarcely raised at all (Textfig. 5F). At small diameters, the ribbing is quite bold (Pl. 5, fig. 1 ), with well-differentiated primaries and secondaries, and frequent-marked constrictions. On the middle whorls, the primary ribbing may be quite distinct (25 ribs per whorl at $150 \mathrm{~mm}$, Pl. 2, fig. 1), or it may be faint or even non-existent. The coiling at these diameters is quite intense, with considerable overlap of the previous whorl and the umbilical diameter less than the whorl height. At $120 \mathrm{~mm}$, uncoiling starts. At large diameters, the umbilical diameter is much greater than the whorl height.

Stratigraphical range. R. anglica typifies the Pseudocordata Subzone. It is much less common in the Pseudoyo Subzone and has never been recorded from the Evoluta Subzone.

Remarks. Both Buckman (1921, pl. 225) and Arkell (1933, pl. 38) stated that the specimens from the Westbury Ironstone which they were figuring as $R$. anglica were 'topotypes', i.e. from the same locality as the type, but neither author formally designated the sole specimen from Westbury figured by Salfeld in his type series of $R$. anglica as lectotype. The species is distinguished from other moderately evolute morphospecies of Ringsteadia by the extremely slim whorl section, with maximum breadth of the whorl being at the mid-point of the whorl side (Text-fig. 5F).

3. Ringsteadia marstonensis group

Ringsteadia pseudocordata (Blake and Hudleston, 1877)

Plate 1, figure 5; Plate 3, figures 1, 3; Text-figures 5I-J, 7A

1877 Ammonites pseudocordatus Blake and Hudleston, p. 392 , pl. 13 , fig. 1 .

non 1917 Ringsteadia pseudocordata (Blake and Hudleston); Salfeld, pl. 10, fig. 1a-b.

\section{EXPLANATION OF PLATE 9}

Figs 1, 3, 7. Pictonia densicostata Buckman, var. praebaylei nov. 1, SMC J47913, ×0.9; 3, NHM C93791, ×0.85. 7, NHM C93793, ×0.45. Fig. 2. Pictonia densicostata Buckman, SMC J47867, $\times 0.85$.

Fig. 4. Prorasenia bowerbanki Spath, Kimmeridge Clay, Baylei Zone, Bourton Bypass, DK35, $\times 1.0$.

Figs 5-6. Pictonia densicostata Buckman, var. dorsetensis nov., type of var., DK31; 5, $\times 0.65 ; 6, \times 0.9$.

Fig. 8. Pictonia densicostata Buckman var. grandicostata nov., DK32, $\times 0.6$.

Specimens figured in 1, 2, 3, 7, 8 from the Inconstans Bed, Baylei Zone, of Ringstead Bay; 5-6 from the Inconstans Bed of Black Head; 1-2 and 5-6 are septate inner whorls; 4 has a fragment of the body chamber showing a terminal constriction and part of a lappet. Scale bars represent $10 \mathrm{~mm}$. No scale bar = natural size. 


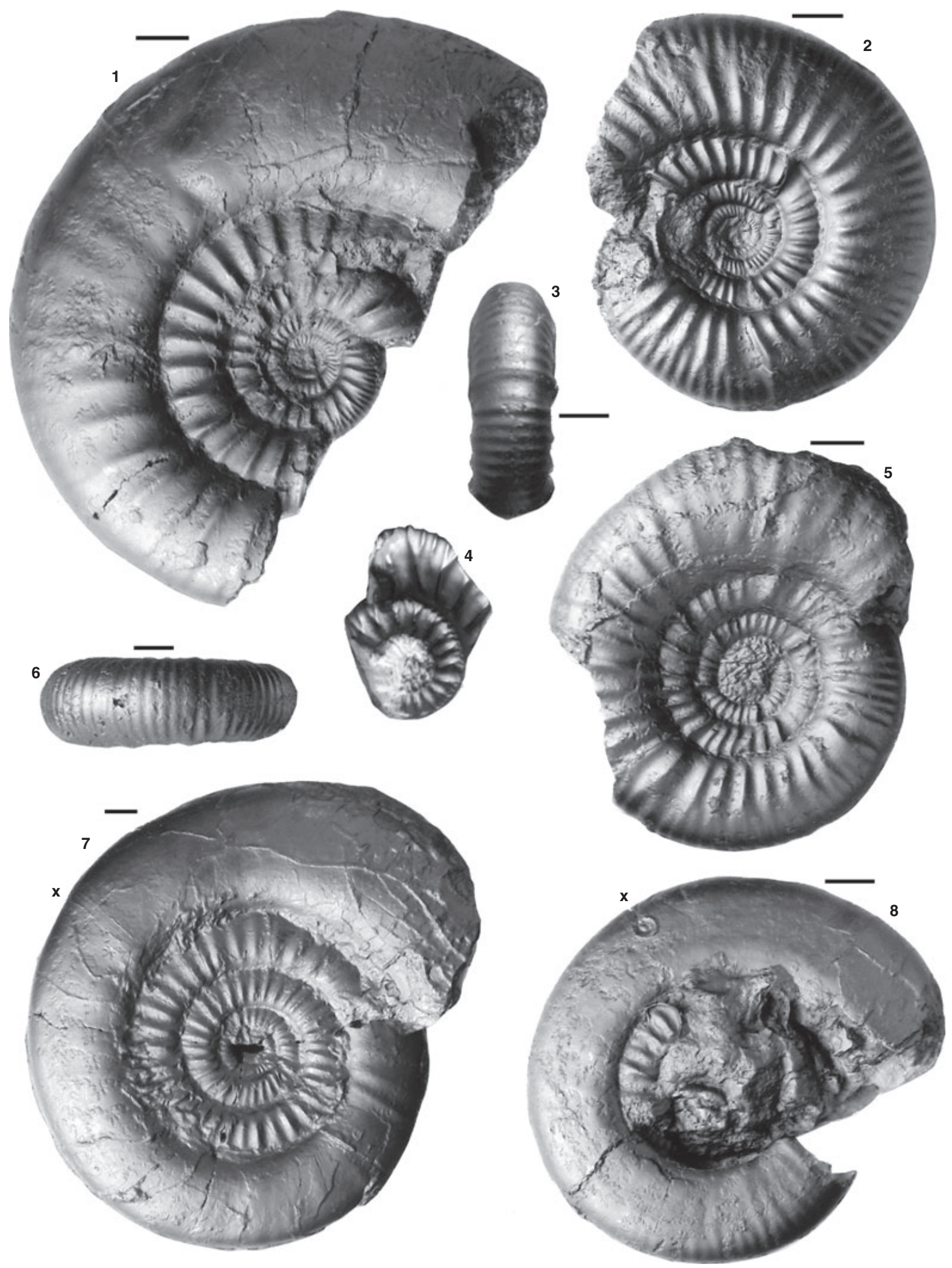

WRIGHT, Pictonia, Prorasenia 
non 1925 Ringsteadia pseudo-cordata Blake and Hudleston emend Salfeld; Dohm, p. 27, pl. 1, figs 8, 9, pl. 3, fig. 3, pl. 6, figs 9, 10, pl. 8, fig. 2, pl. 9, figs 1,3 .

1925 a Ringsteadia pseudocordata (Blake and Hudleston); Buckman, pls. 560A, 560B.

$1925 b$ Ringsteadia frequens Salfeld; Buckman, pl. 589.

1933 Ringsteadia anglica Salfeld; Arkell, pl. 38, fig. 1.

2003 Ringsteadia pseudocordata (Blake and Hudleston); Wright, fig. 9a.

Type material. Holotype (BGS GSM46264) from the Westbury Ironstone of Westbury, Wiltshire, figured by Buckman (1925a, pls 560A, 560B). Var. nudus; type of var. (SM72) from the Marston Ironstone of the Keypoint site, Swindon.

Measurements. Holotype: $\mathrm{D}(\max ) 190 \mathrm{~mm}$; at $190 \mathrm{~mm}, 0.36$, $0.25,0.35$. BGS GSM97554: D(phg-?ad) $230 \mathrm{~mm}, \mathrm{D}(\max )$ $290 \mathrm{~mm}$; at $290 \mathrm{~mm}, 0.35,0.16,0.36,27$ ribs at $240 \mathrm{~mm} ; 0.3 \mathrm{wh}$ bch. OUM J14615 (figured Wright, 2003): D(max) $119 \mathrm{~mm}$; at $119 \mathrm{~mm}, 0.38,0.30,0.34,32$ ribs.

SMC J44984 (pl. 3, fig. 1): $\mathrm{D}(\max ) 116 \mathrm{~mm}$; at $116 \mathrm{~mm}, 0.36$, $0.28,0.35,29$ ribs at $97 \mathrm{~mm}$.

Var. nudus: SM72. Type of var. (Pl. 1, fig. 5), SM72: D(phg-ad) $150 \mathrm{~mm}, \mathrm{D}(\max ) 190 \mathrm{~mm}, 0.5 \mathrm{wh} \mathrm{bch}$; at $190 \mathrm{~mm}, 0.35,0.22$, 0.34. SM244: D(phg-ad) $155 \mathrm{~mm}, \mathrm{D}(\max ) 190 \mathrm{~mm}, 0.5$ wh bch.

Description. R. pseudocordata is the most involute of the R. marstonensis group, with the umbilical width is about equal to the whorl height (31-36\% of the diameter). The development of ribbing is very variable. Strong, wiry, slightly prorsiradiate primary ribs, 27 per whorl, are present at $20 \mathrm{~mm}$, with strong constrictions (Pl. 3, fig. 1). At $40-45 \mathrm{~mm}$, the primary ribs become flatter and more rounded. The secondaries, first seen at $75 \mathrm{~mm}$ in Plate 3, figure 1, are quite weak, 2 or 3 per primary. They usually arise in sheaves of three secondaries, although there is some bifurcation. The whorl thickness is at its maximum just above the umbilical margin, and the sides then slope to the rounded venter, giving an elliptical whorl section (Text-fig. 5I-J). There is every variation from strongly ribbed forms through more gently ribbed ones (Pl. 3, fig. 3) to forms that are smooth even at $80 \mathrm{~mm}$ (Pl. 1, fig. 5). Such weakly ribbed or smooth forms form a distinct majority of the specimens collected at South Marston and may be distinguished as var. nudus nov. They become adult at much earlier diameters than the ribbed forms (SM72, SM244 above). If ribbing is present, it is maintained to at least $190 \mathrm{~mm}$ on the phragmocone, as seen on the holotype.
Stratigraphical range. The Pseudoyo and Pseudocordata Subzones are characterized by this moderately evolute form of Ringsteadia, which, next to $R$. brandesi, is the most common Ringsteadia in the two lower subzones of the Pseudocordata Zone.

Remarks. R. pseudocordata is characterized by sharp, regular ribbing on the inner whorls (Pl. 3, fig. 1), whereas the similarly evolute $R$. evoluta frequently has irregularly ribbed inner whorls much affected by constrictions (Pl. 8, figs 3, 5). The specimens from north-west Poland figured as $R$. pseudocordata by Dohm (1925) show a combination of features not found in English specimens and should not be placed in this species. The ribbing of the inner whorls is more dense than that of the specimens described here, with a smooth outer phragmocone and a body chamber with coarse, rounded ribbing. The crosssection is flat sided on the middle whorls, then developing a ventrolateral spiral depression to give an acute, rounded venter on the body chamber. However, a Polish specimen very close to $R$. pseudocordata, described originally as Proplanulites teisseyrei (Siemiradzki 1891), is present in the Siemiradzki Collection in Krakow, from Trzebinia, southern Poland (Głowniak and Wierzbowski 2007).

Ringsteadia marstonensis Salfeld, 1917

Plate 1, figure 4; Plate 3, figures 4, 6; Plate 4, figure 3; Text-figures $6 \mathrm{~A}, \mathrm{C}, 7 \mathrm{G}-\mathrm{H}$

1917 Ringsteadia marstonensis Salfeld, p. 83, pl. 11, figs $1 \mathrm{a}-\mathrm{b}$.

non 1925 Ringsteadia marstonensis Salfeld; Dohm, p. 28, pl. 2, figs 5-6, pl. 3, fig. 1

non 1925 Ringsteadia cf. marstonensis Salfeld; Dohm, p. 28 , pl. 6 , figs 7,11 .

non 1962 Ringsteadia marstonensis Salfeld; Wilczynski pp. 64-66, pls 1, 2.

non 1962 Ringsteadia cf. marstonensis Salfeld; Wilczynski, p. 66 , pl. 3 , fig. 1

non 1988 Ringsteadia marstonensis Salfeld; Mesezhnikov, pl. 9, fig. 13.

\section{EXPLANATION OF PLATE 10}

Figs 1, 3. Pictonia seminudata (Buckman) var. ringsteadensis nov.: 1 , type of var., DK8, $\times 0.7 ; 3$, OUM J37712, $\times 0.5$.

Fig. 2. Pictonia densicostata Buckman var grandicostata nov., type of var, SMC J47868, $\times 0.75$.

Fig. 4. Pictonia densicostata Buckman, OUM J67110, $\times 0.85$.

Figs 5-6. Prorasenia cf. hardyi Spath, $\times 1.0$ : 5, SMC J47351; 6, DK33.

All specimens from the Inconstans Bed, Baylei Zone, of Ringstead Bay. In 3, the outer whorl as preserved is body chamber; 5 is largely complete, with the aperture including a prominent lappet partly preserved on the reverse behind the label; 6 is a body chamber fragment. Scale bar represent $10 \mathrm{~mm}$. No scale bar = natural size. 
PLATE 10

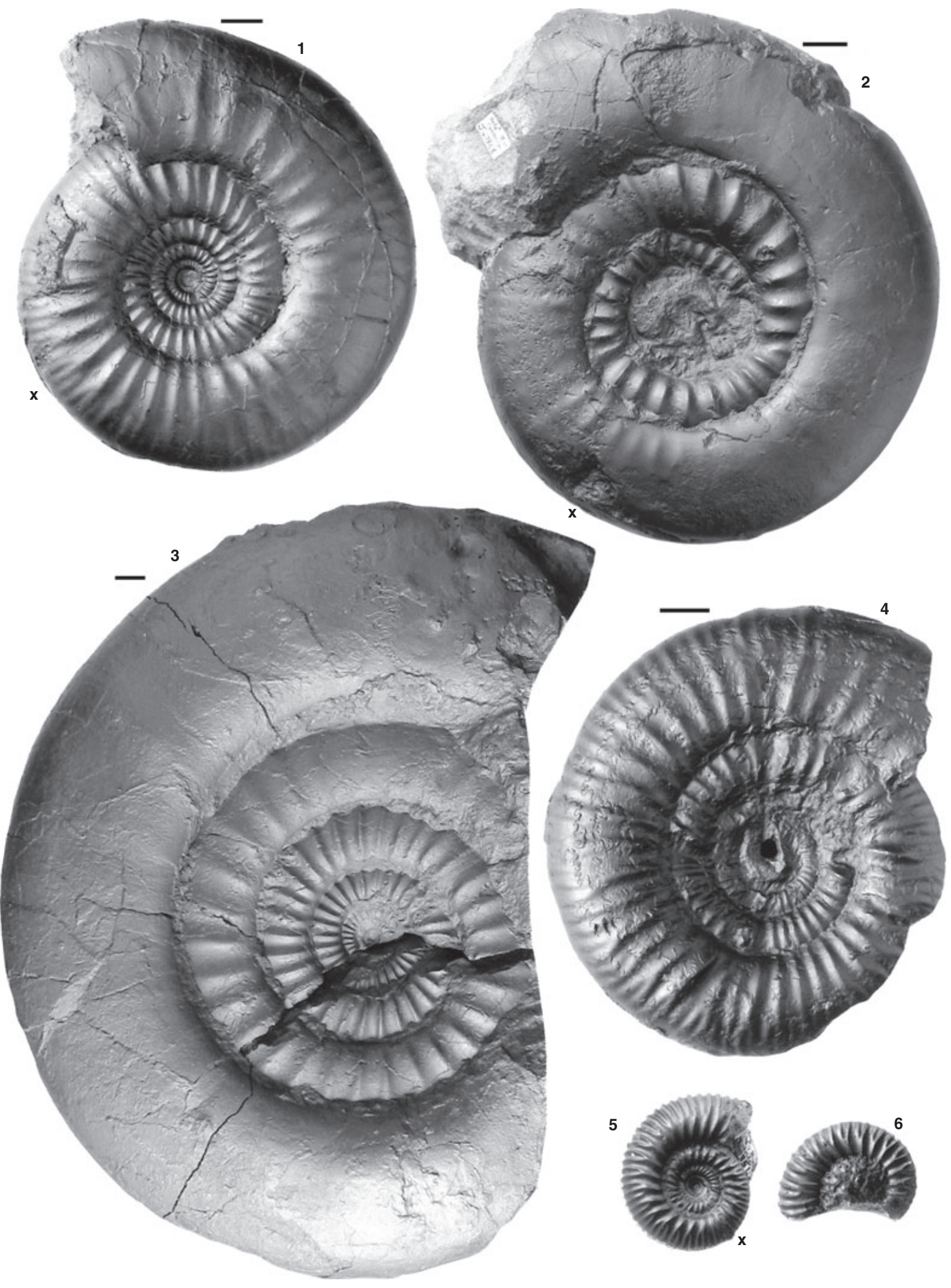

WRIGHT, Pictonia, Prorasenia 


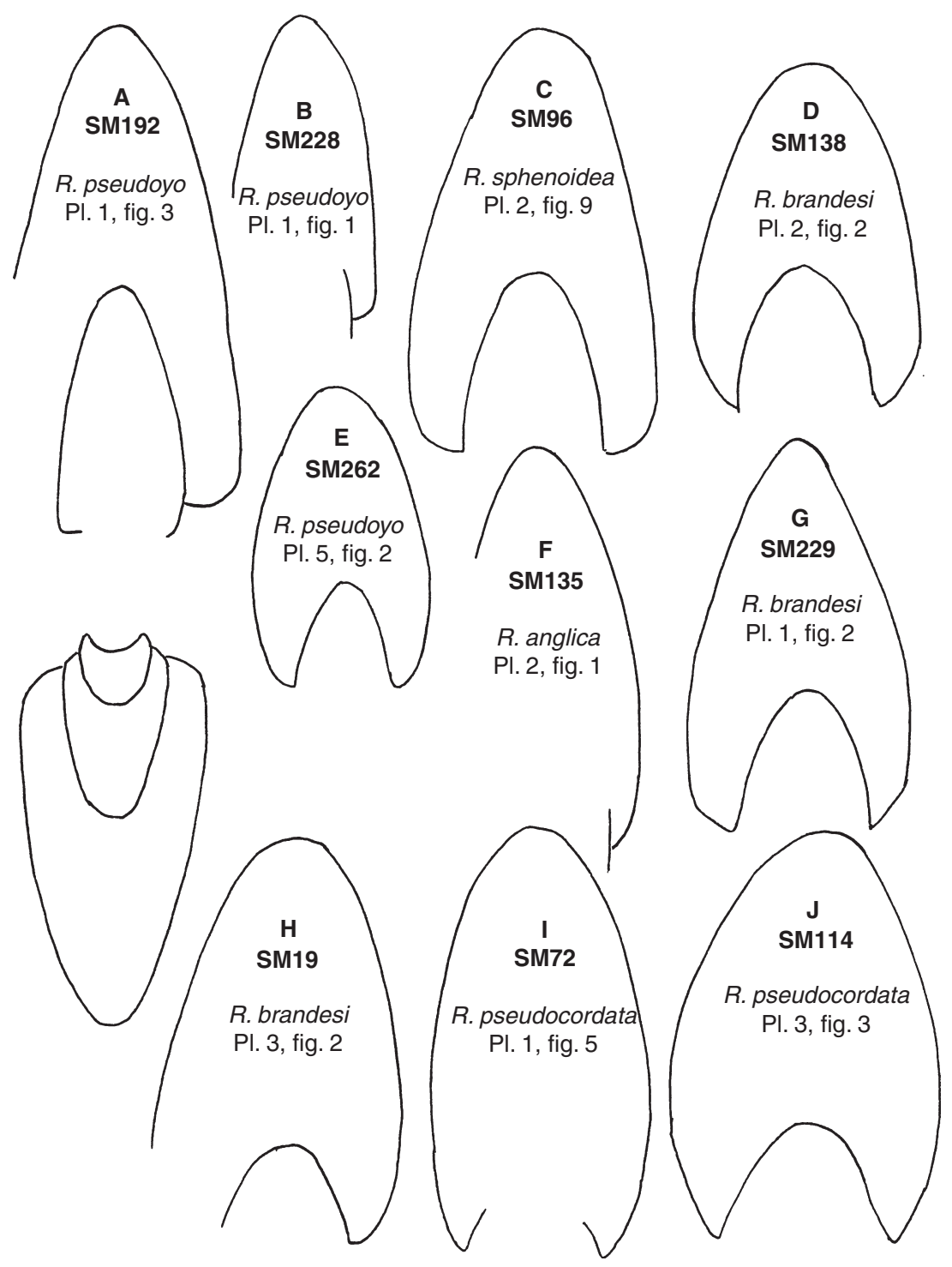

TEXT-FIG. 5. Whorl sections of Ringsteadia from South Marston.

Type material. Salfeld (1917) figured two syntypes, but one was subsequently designated the holotype of $R$. bassettensis by Spath (1935). The remaining syntype (Salfeld, 1917, pl. 11, figs 1a, b, NHM C15427), from the Marston Ironstone of South Marston, thus becomes the holotype.

Measurements. Holotype: $\mathrm{D}(\max ) 148 \mathrm{~mm}$; at $148 \mathrm{~mm}, 0.36$, $0.32,0.38$. BGS GSM97555: $\mathrm{D}(\max ) 142 \mathrm{~mm}$; at $142 \mathrm{~mm}, 0.30$, $0.19,0.44$. DC126: $\mathrm{D}(\max ) 210 \mathrm{~mm}$; at $145 \mathrm{~mm}, 0.39,0.32$, 0.37. SM115 (Pl. 4, fig. 3): D(phg-?ad) $205 \mathrm{~mm}$; at $201 \mathrm{~mm}$ : $0.35,0.25,0.42 ; 17$ ribs per half whorl at $180 \mathrm{~mm}$.

Description. R. marstonensis has the umbilical width ranging from 36 per cent to 42 per cent of the shell diameter, as against whorl heights ranging from 34 per cent to 37 per cent ('e', Textfig. 8A). The whorl breadth is about two thirds of the whorl height (Text-fig. 6A, C). On the early whorls, at $30 \mathrm{~mm}$ diameter (Pl. 3, fig. 4), bold, prorsiradiate primaries bifurcate or occasionally trifurcate into less prominent, rectiradiate secondaries, this bold and rod-like ribbing continuing to at least $210 \mathrm{~mm} \mathrm{(Pl.} \mathrm{4,}$ fig. 3). The secondaries arise in a very irregular manner (Pl. 1, fig. 4). Bifurcation may take place low on the whorl side or near the ventro-lateral margin. Primary ribs may pass into a sheaf of 3 or 4 secondaries or may continue over the whorl side as a simple rib (Pl. 4, fig. 3). The secondaries then run strongly over the venter. The holotype has sheaves of secondaries, 6 per primary, at $150 \mathrm{~mm}$. The ribbing may fade completely, Plate 3, figure 6 showing the shell almost smooth at $120 \mathrm{~mm}$.

Stratigraphical range. R. marstonensis is common in the Pseudoyo and Pseudocordata subzones, and scarce in the Evoluta Subzone, one specimen from the Osmington Mills Ironstone (DC126) showing the characteristic features very well.

Remarks. R. marstonensis was introduced by Salfeld (1917) for all evolute, round-whorled Ringsteadia. The 
TEXT-FIG. 6. Whorl sections of Ringsteadia from South Marston and from south Dorset. strength of the ribbing on the outer phragmocone is so variable, however, that the name is now reserved for evolute forms where the ribbing fades and is lost at diameters of 150-200 mm (Pl. 3, fig. 6; Pl. 4, fig. 3). In forms with bolder, often coarse ribbing at these diameters are included in $R$. bassettensis. The specimens figured by Dohm (1925) and Wilczynski (1962) from north-west Poland should not be allocated to $R$. marstonensis. Admittedly, they have the moderately coarse primary ribbing characteristic of the marstonensis group, but this is superimposed on flattened whorl sides running up to a tall, acute, rounded venter. British specimens of $R$. marstonensis have an elliptical whorl section (Text-fig. 6A, C).

Ringsteadia bassettensis Spath, 1935

Plate 3, figure 5, Plate 4, figures 1, 2, 4, 5; Text-figures 6B, D-G

1917 Ringsteadia marstonensis Salfeld, pl. 11, fig. 2a-b.

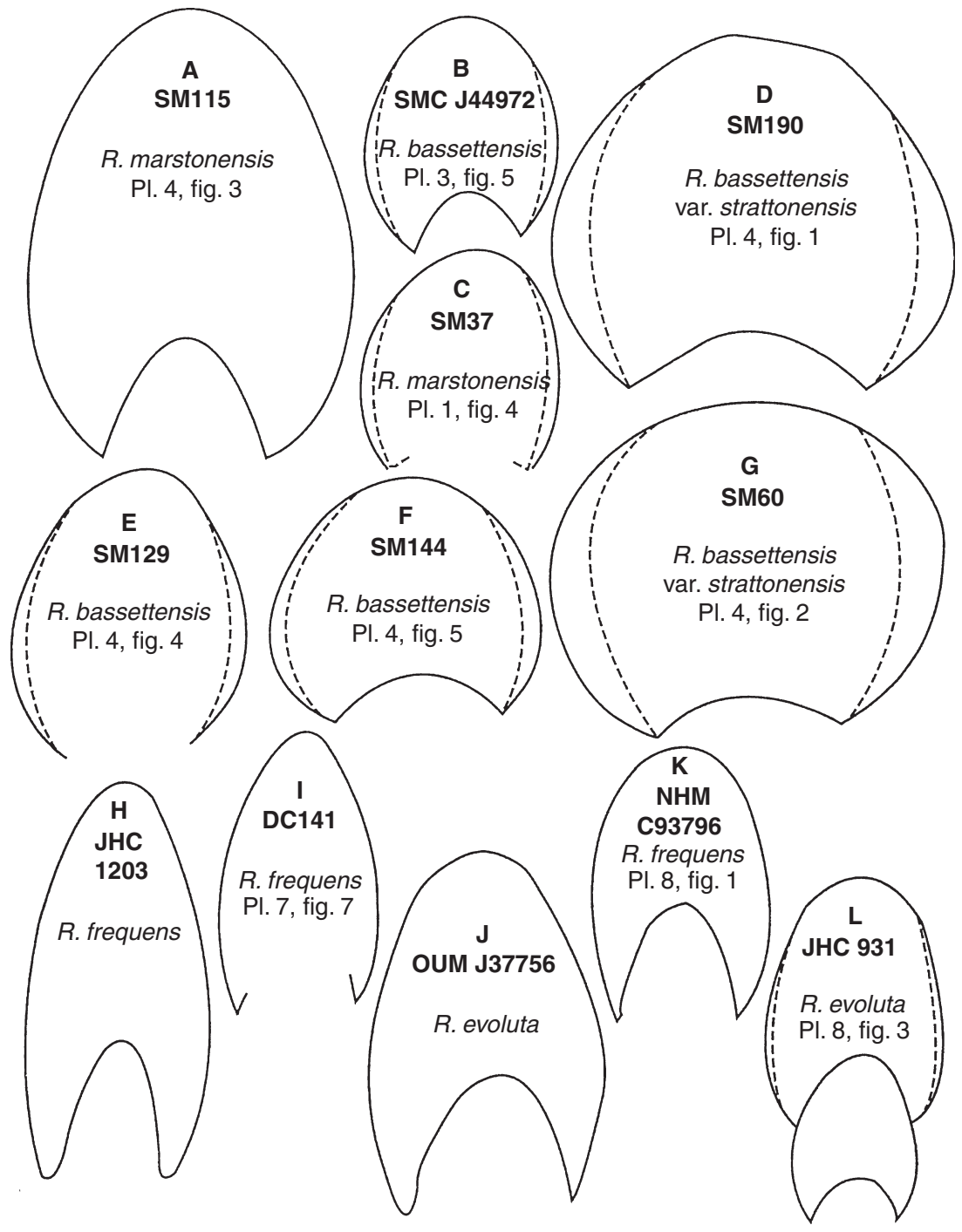

1935 Ringsteadia bassettensis Spath, p. 41, pl. 12, fig. $3 \mathrm{a}-\mathrm{b}$.

1947a ?Decipia (?Pomerania) marstonensis Arkell, p. 377, pl. 78 , fig. $8 \mathrm{a}, \mathrm{b}$.

1948 Pachypictonia marstonensis (Arkell); Arkell, p. 402.

Type material. Holotype, designated by Spath (1935), figured Salfeld, 1917, pl. 11, fig. 2a, b, NHM C15426, from the Marston Ironstone of Wootton Bassett. Var. strattonensis; type of var. (Taunton Castle Museum 3670) from the Marston Ironstone of Stratton St Margaret, Swindon.

Measurements. Holotype: $\mathrm{D}(\max ) 115 \mathrm{~mm}$; at $115 \mathrm{~mm}, 0.35$, 0.31 , 0.40. SMC J44972 (Pl. 3, fig. 5): $\mathrm{D}(\max ) 118 \mathrm{~mm}$; at $118 \mathrm{~mm}, 0.30,0.25,0.46$.

Description. Spath (1935) introduced this name for the more coarsely ribbed variants of $R$. marstonensis Salfeld (1917). Bold, rod-like, rectiradiate primary ribs are present at $23 \mathrm{~mm}$, and these continue with little change to $115 \mathrm{~mm}$ (Pl. 3, fig. 5), where 


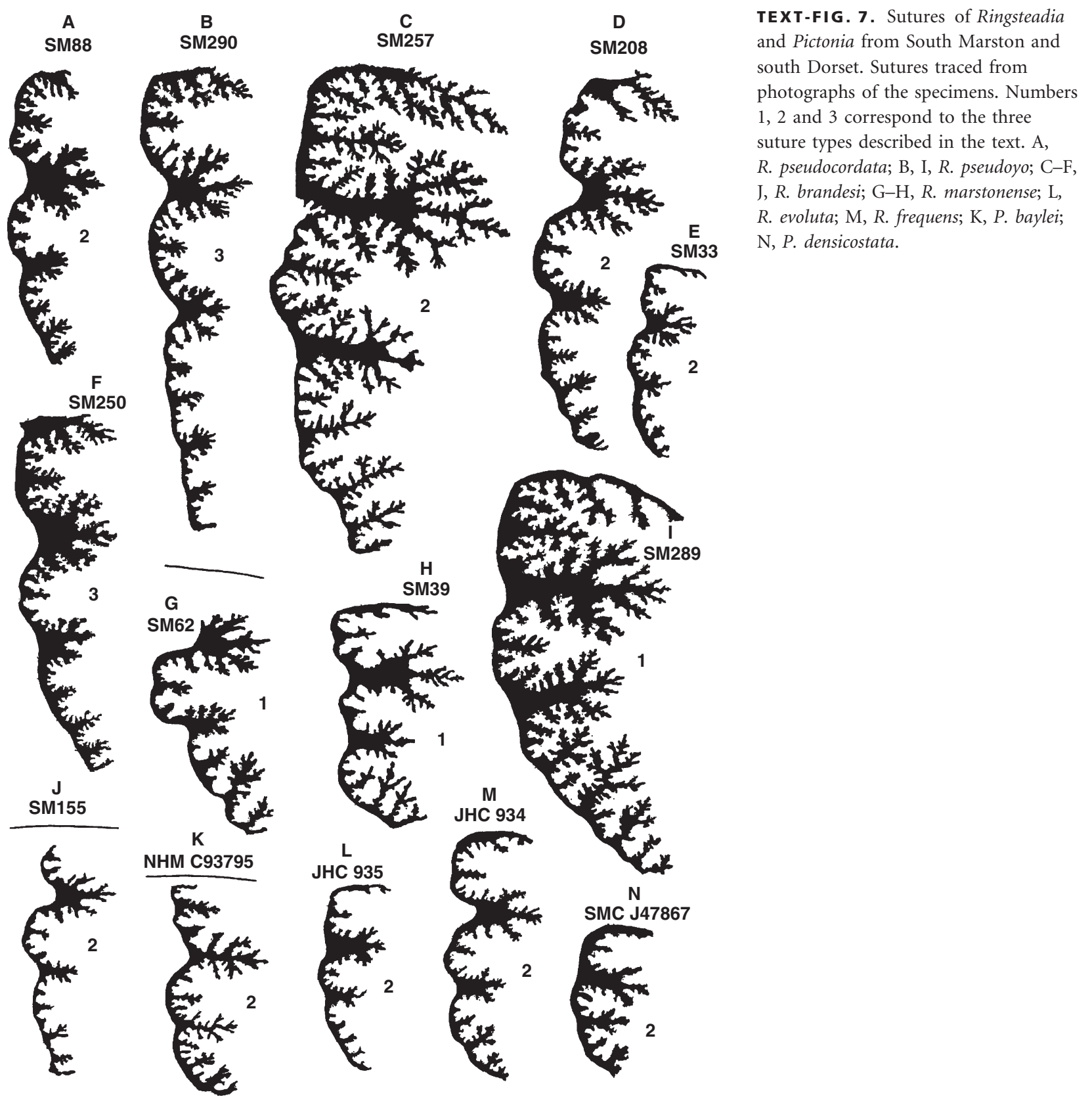

there are $30 \mathrm{rpw}$. The secondaries arise in a very irregular fashion, either by bifurcation from the primaries, with one intercalatory, or by passing of primaries into sheaves of three secondaries. Middle whorl fragments have coarse primary ribbing, approximately 6 per quarter whorl. The ribbing may be gently raised (Pl. 4, fig. 5) or markedly raised as in Perisphinctes (Kranaosphinctes) ariprepes Buckman (Pl. 4, fig. 4). The whorl section is completely rounded, sometimes broader than high (Text-fig. 6B, E-F).

Var. strattonensis. Arkell (1947a) figured a coarsely ribbed aulacostephanid as ?Decipia (?Pomerania) marstonensis, and later ascribed the specimen to Pachypictonia (Arkell, 1948). This species is, however, an extremely coarsely ribbed variant of Ringsteadia, and fits nicely as a variety of R. bassettensis. The distinctive features of var. strattonensis (named after Stratton St Margaret, the village on the north-eastern outskirts of Swindon) are the ribbing and whorl section, demonstrated in the two fragments illustrated in Plate 4, figures 1-2, with cross-sections in Text-figure 6D, G. The early ribbing is very low, becoming almost nonexistent at the diameter of $70-80 \mathrm{~mm}$ (Pl. 4, fig. 2). In the later part of the phragmocone (Pl. 4, figs $1,2)$, there is the sudden development of very coarse, wedgeshaped ribs. The whorl breadth is 120 per cent of the whorl height (Text-fig. 6D, G). The suture, well seen in Plate 4, figure 2, is clearly of the normal Group 3 Ringsteadia type (see below). 
Stratigraphical range. $R$. bassettensis is moderately common in the Pseudoyo and Pseudocordata subzones.

Remarks. So close is the style of ribbing of $R$. bassettensis to that of $P$. (Kranaosphinctes) spp. sensu Głowniak (2002) in the mid to late whorls that it may only be possible to allocate fragmentary specimens to the correct taxon, Ringsteadia or Kranaosphinctes, if the suture is visible, noting the distinct angle between the first and second lateral lobes of Kranaosphinctes (Wright, 2003, fig. 9b) compared with the parallel lobes of evolute Ringsteadia (e.g. Text-fig. $7 \mathrm{H}$ ).

Ringsteadia frequens Salfeld, 1917

Plate 6, figures 1, 4-5; Plate 7, figures 1, 7; Plate 8, figure 1; Text-figures $6 \mathrm{H}-\mathrm{I}, \mathrm{K}, 7 \mathrm{M}$

1917 Ringsteadia frequens Salfeld, p. 81, pl. 9, figs 2a-b, 3.

1917 Ringsteadia brandesi Salfeld, p. 77, pl. 11, fig. 3a-b.

1917 Ringsteadia pseudo-cordata Blake emend. Salfeld, pl. 10, fig. 1a-b.

?1917 Ringsteadia frequens Salfeld, p. 81.

non 1925 Ringsteadia frequens Salfeld; Dohm, p. 28, pl. 5, fig. 7; pl. 6, fig. 1; pl. 8. fig. 1.

non 1925b Ringsteadia frequens Salfeld; Buckman, pl. 589.

Type material. Two syntypes; lectotype (Salfeld, 1917, pl. 9, fig. 2a-b, NHM C24092) designated by Buckman (1925b, pl. 589), from the uppermost Ampthill Clay (not Marston Ironstone) of Wootton Bassett. This is the first of the two specimens in Salfeld's plate, and as such is justifiably regarded as type. Second syntype from ?Osmington Mills Ironstone of Sandsfoot Castle.

Measurements. Lectotype: $\mathrm{D}(\max ) 130 \mathrm{~mm}$; at $70 \mathrm{~mm}, 0.46$, $0.32,0.31$; at $102 \mathrm{~mm}, 0.39,0.26,0.31$; at $127 \mathrm{~mm}, 0.36,0.24$, 0.35. DC141 (Pl. 7, fig. 7): $\mathrm{D}(\max )$ c $97 \mathrm{~mm}$; at $90 \mathrm{~mm}, 0.40$, $0.27,0.30$. JHC 1203: $\mathrm{D}(\max ) 182 \mathrm{~mm}$; at $182 \mathrm{~mm}$; 0.38, 0.20 , 0.29. NHM C93796 (Pl. 8, fig. 1): D(max) $113 \mathrm{~mm}$; at $113 \mathrm{~mm}$, $0.37,0.25,0.31$. OUM J13104 (Pl. 7, fig. 1): D $(\max ) 138 \mathrm{~mm}$; at $118 \mathrm{~mm}, 0.38,0.22,0.32$. SMC J44958 (Pl. 6, fig. 4): $\mathrm{D}(\max )$ $101 \mathrm{~mm}$; at $101 \mathrm{~mm}, 0.42,0.26,0.26 .27$ ribs. SMC J44959 (Pl. 6, fig. 5); D(phg-ad) c. $150 \mathrm{~mm}, \mathrm{D}(\max )$ c. $180 \mathrm{~mm}$, 0.25 wh bch, ribs ?25 at $110 \mathrm{~mm}$. SMC J44964: D(phg-?ad) $185 \mathrm{~mm}$; at $148 \mathrm{~mm} ; 0.39,0.27,0.34$.

Description. The lectotype is moderately evolute (' $\mathrm{i}$ ', Textfig. 8C). The last quarter of a whorl seen is starting to uncoil, a feature also seen in Plate 7, figure 1. Before that, the whorl height is greater than the umbilical width. Specimens from south Dorset display the typical strong, prorsiradiate primary ribbing on the inner whorls, ranging from 21 to $29 \mathrm{rpw}$, with marked constrictions and raised ribs (Pl. 6, fig. 4; Pl. 7, fig. 7). The secondaries tend to arise from a broadening of the primary below the mid-point of the whorl side passing into sheaves of 3 or 4 secondaries (Pl. 6, fig. 4). In some specimens, a smooth, spiral band separates secondaries and primaries (Pl. 6, figs 1,5). This is also seen in Salfeld's plate 10, figure 1a (incorrectly included in R. pseudocordata).

Stratigraphical range. R. frequens typifies the Evoluta Subzone as represented by the Osmington Mills Ironstone, the Ringstead Clay in north Dorset and the uppermost Ampthill Clay in Wiltshire.

Remarks. $R$. frequens is distinguished from $R$. brandesi by differences in the ribbing. The secondaries in $R$. brandesi arise in triplicate sheaves or groups of three leading on directly from the primary ( $\mathrm{Pl}$. 2, figs 2-3). In R. frequens, a slight forward flexure of the primary rib leads to a broadened primary from which arise indistinct sheaves of three or four secondaries (Pl. 6, fig. 4; Pl. 8, fig. 1). Constrictions can be present in both morphospecies, but in $R$. frequens, these may be followed by a flared primary rib (Pl. 7, fig. 7). The maximum whorl breadth in $R$. frequens is not as close to the umbilicus as in $R$. brandesi (Text-fig. $6 \mathrm{H}, \mathrm{K}$ ). The specimen figured as R. frequens by Dohm (1925), although quite close to $R$. frequens, has a cross-section changing from ovalwhorled to fastigate. Salfeld (1917) recorded three specimens of $R$. frequens from the Upper Korallenoolith of the Hannover region (Galgenberg, Hoheneggelsen), and one from northern France (Argilles brunes de Cricqueboeuf of Villerville, south of Cap de la Hève).

Ringsteadia evoluta Salfeld, 1917

Plate 6, figures 3, 6; Plate 8, figures 3-5; Text-figures $6 \mathrm{~J}, \mathrm{~L}, 7 \mathrm{~L}$

1917 Ringsteadia evoluta Salfeld, p. 84, pl. 12, fig. 1a-b. 1972 ?Decipia sp.; Malinowska, pl. 12, fig. 3.

?1988 Ringsteadia marstonense Salfeld; Mesezhnikov, pl. 9, fig. 13.

2006 Ringsteadia evoluta Salfeld; Matyja et al., fig. 4d-e.

Type material. Holotype (Museum of Geology and Palaeontology of Göttingen University Collection, 449/1) from the 'lower Kimmeridge Clay or Upper Corallian of Osmington near Weymouth' (Salfeld, 1917, p. 84) - presumably the Osmington Mills Ironstone of Osmington Mills.

Measurements. BGS GSM5770: $\mathrm{D}(\max ) 148 \mathrm{~mm}$; at $148 \mathrm{~mm}$, $0.35,0.22,0.35$. DC122 (Pl. 8, fig. 5): $\mathrm{D}$ (phg-ad) $150 \mathrm{~mm}$, $\mathrm{D}(\max )$ c. $170 \mathrm{~mm}, 0.2 \mathrm{wh}$. bc. At $124 \mathrm{~mm}, 0.36,0.26,0.37 .26$ ribs at $80 \mathrm{~mm}$. DC139 (Pl. 6, fig. 3): $\mathrm{D}(\max ) 63 \mathrm{~mm}$. At $63 \mathrm{~mm}$; 0.36, 0.29, 0.38. JHC 931 (Pl. 8, fig. 3): $\mathrm{D}(\max )$ $114 \mathrm{~mm}$. At $114 \mathrm{~mm}, 0.32,0.23,0.38$. JHC 932 (Pl. 8, fig. 4): $\mathrm{D}$ (phg-juv) $115 \mathrm{~mm}, \mathrm{D}(\max ) 130 \mathrm{~mm}, 0.2 \mathrm{wh}$ bch; at $130 \mathrm{~mm}$, 0.31, 0.21, 0.43. JHC 934: $\mathrm{D}$ (phg-?ad) $175 \mathrm{~mm}, \mathrm{D}(\max )$ $190 \mathrm{~mm}, 0.1 \mathrm{wh} \mathrm{bch}$; at $170 \mathrm{~mm}, 0.37,0.24,0.38,26$ ribs at 


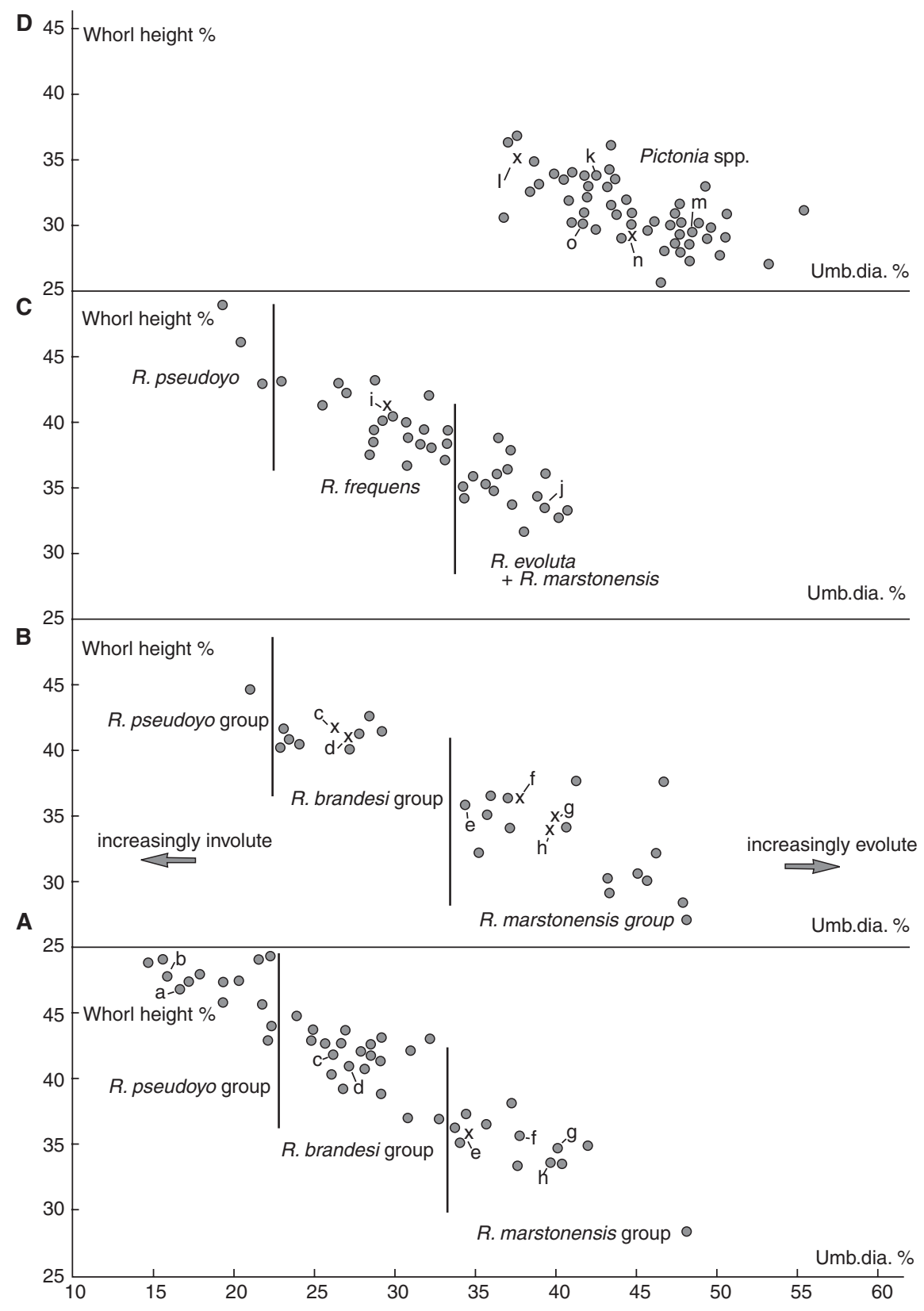

TEXT-FIG. 8. Plots of the ratios of whorl height against umbilical diameter, expressed as a percentage of the shell diameter, in Ringsteadia and Pictonia. A, Pseudoyo Subzone, Marston Ironstone; B, Pseudocordata Subzone, Westbury Ironstone; C, Evoluta Subzone, Osmington Mills Ironstone; D, Baylei Zone, Inconstans Bed, Dorset coast. X = type specimen not from the locality or horizon in question. 8A, shows a good spread through the whole range of morphologies from the highly involute $R$. pseudoyo group to the evolute R. marstonense group. a, R. pseudoyo (lectotype); b, R. sphenoidea (holotype); c, R. brandesi (lectotype); d, $R$. anglica (lectotype); e, R. pseudocordata (holotype); f, R. marstonensis (holotype); g, R. bassettensis var. strattonensis (type of var.); h, R. bassettensis (holotype). In $8 \mathrm{~B}$, the Pseudocordata Subzone fauna plots differently, with the pseudoyo group very scarce, and a predominance of the evolute marstonense group. $8 \mathrm{C}$ shows that the range of variation in the Evoluta Subzone is less than in the earlier subzones. Almost all Ringsteadia can be accommodated within two morphospecies, $R$. frequens and $R$. evoluta, although continued use of $R$. pseudoyo for the more involute forms, and R. marstonensis for depressed forms, is still necessary. (i) R. frequens (lectotype); (j) R. evoluta (holotype). In $8 \mathrm{D}$ specimens of Pictonia plot out very differently, all lying at the evolute end of the plot line and within a comparatively close scatter of dots. There is thus a distinct break between the Ringsteadia and Pictonia populations. Unlike Ringsteadia, species in Pictonia are determined by the style of ribbing, not the proportions of the conch. $\mathrm{k}, P$. densicostata var. dorsetensis (type of var.); 1 , P. seminudatus; $\mathrm{m}$, P. densicostata (holotype); $\mathrm{n}$, P. densicostata var. praebaylei (type of var.); o, P. seminudatus var. ringsteadensis (type of var.). 
$170 \mathrm{~mm}$. JHC 935: D(phg-juv) $130 \mathrm{~mm}, \mathrm{D}(\max ) 160 \mathrm{~mm}$, $0.5 \mathrm{wh}$ bch; at $145 \mathrm{~mm}, 0.34,0.25,0.41$.

Description. The holotype (Salfeld, 1917, pl. 12) is of an unusual smooth, rapidly uncoiling variety. However, it does show one characteristic feature of the species, which is the umbilical seam lying at about the mid-point of the whorl side at medium diameters (' $j$ ', Text-fig. 8C), uncoiling further on the body chamber. Plate 8 figure 5 is more typical of the species, with its irregular, gently raised ribbing. Sheaves of 3 or 4 secondaries may arise from a broadening of the primary below the mid-point of the whorl side, but these alternate with frequent strong, simple ribs associated with constrictions (Pl. 6, fig. 3; Pl. 8, fig. 3). More coarsely ribbed forms may show bifurcation of secondaries (Pl. 6, fig. 6), the bifurcation points being well below the midpoint of the whorl side. The ribs begin to fade about $70 \mathrm{~mm}$ diameter, although gently raised primary ribs continue to $150 \mathrm{~mm}$ in most specimens, passing indistinctly into very faint secondaries, which fade over the venter.

Stratigraphical range. $R$. evoluta is by far the most abundant species of Ringsteadia in the Evoluta Subzone of both north and south Dorset.

Remarks. R. evoluta is best distinguished from R. marstonensis by rib style. In $R$. marstonensis, bold primary ribs pass into sheaves of three to six secondaries. In $R$. evoluta, although in the early whorls there may be strong primaries with biplicate secondaries (Pl. 6, fig. 1; Pl. 7, fig. 3) as in $R$. marstonensis, the primaries in $R$. evoluta rapidly become indistinct, with the frequent insertion of constrictions and simple ribs. Sheaves of three secondaries are indistinctly connected to the primaries. The whorl sides are flatter in R. evoluta (Text-fig. 6L), distinct from the round-whorled $R$. marstonensis. On the later part of the phragmocone, $R$. evoluta may have a smooth spiral band on the whorl side (Pl. 8, fig. 5).

The distinction from Pictonia is also clear. Throughout the ribbed portion of its whorl, the strong primaries of Pictonia bifurcate into secondaries with frequent intercalated ribs running in between the bifid pairs. In contrast, $R$. evoluta (and also R. frequens) has only gently raised primaries that normally pass below the mid-point of the whorl side into sheaves of three or four secondaries. The strong constrictions and flared simple ribs of some R. evoluta (Pl. 6, figs 3,6) affect the ribbing over the venter much more than is usual in Pictonia.

Malinowska's (1972) ?Decipia sp. from the Pseudocordata Zone of Czestochowa in Poland matches R. evoluta well, although having slightly denser secondary ribbing. The specimen of Ringsteadia figured by Mesezhnikov (1988) from the Ural River Basin of Siberia matches closely some of the Dorset specimens in its gentle primary ribbing and very faint secondaries. Schweigert and Callomon (1997) recorded R. evoluta from Lochengebiet in the Swabian Jura from the tizianiformis Horizon of the Hauffinaum Subzone, a horizon that Melendez (2002) has proposed as the highest Oxfordian horizon in the Sub-Mediterranean Upper Oxfordian.

\section{Genus PICTONIA Bayle, 1878}

Type species. Pictonia baylei Salfeld, 1913 (pro Pictonia cymodoce Bayle, 1878 non d'Orbigny, 1850), by subsequent designation by ICZN under its plenary powers in Opinion 426, 1956 [Bulletin on Zoological Nomenclature 14, 259-280]. Bayle's text to his Atlas never having been published, the interpretation of his genus became focussed on his illustrations (Bayle, 1878, pl. 66, figs 1, 2, from the Baylei Zone Fm. des Calcaires coquilliers of Cap de la Hève, Le Havre). These became the type series of Pictonia baylei, q.v. below.

Remarks. The genus Pictonia comprises medium sized, moderately evolute to evolute aulacostephanids that have sharp, bold primary ribbing and more subdued bifurcating secondary ribbing on the early to middle whorls with frequent additional secondaries intercalated in between bifid pairs. Between three and five strong constrictions are usually, but not always, developed on the middle whorls, each followed by a flared primary rib. The ribbing ends suddenly and the last half whorl of phragmocone and body chamber are smooth. The suture is simple as in some Ringsteadia. In general, Pictonia is an easily recognized taxon, the vast majority of specimens showing the distinctive simple suture, constrictions and flared ribs. Some platycone and depressed varieties lack prominent constrictions, however.

Previous studies of Pictonia have used either 'vertical' (morphological) or 'horizontal' (biospecific) classifications. Hantzpergue's major study of Pictonia (Hantzpergue, 1989) is almost entirely biospecific. The vast majority of Pictonia coming from what Hantzpergue considered to be one isochronous population in the Lower Kimeridgian of Normandy was allocated to the one biospecies Pictonia baylei Salfeld. This was divided into Type 1 (with flared ribs) and Type 2 (flared ribs absent). Each type was subdivided into three groups ranging from compressed to depressed in whorl section. Four specimens separated off by Hantzpergue (1989) as P. thurmanni (Contejean) were subsequently allocated to Pictonia normandiana Tornquist by Schweigert and Callomon (1997). Earlier forms of Pictonia from the Inconstans Bed of southern England were allocated by Hantzpergue (1989) to Pictonia densicostata biosp., again subdivided into six groups divided between two main types. A list of the criteria used by previous authors to distinguish the two principle biospecies of Pictonia are given in the Appendix. 
The problem with this system, as was pointed out by Sykes \& Callomon (1979), is that when, as in this case, there is overlap in morphology between the two biospecies, often one can only allocate a name ( $P$. baylei biosp., $P$. densicostata biosp.) to a specimen if one knows which horizon the specimen came from. Then, the cumbersome reference to, for example, P. baylei, Type 2, Group 3, is necessary. For this reason, I have preferred to use morphospecific names in this account, although introducing new names only as varieties of pre-existing morphospecies. Biohorizons can then be distinguished by the varying proportions of the different morphotypes present in successive populations.

Two main groups of Pictonia are recognized here centred around the existing morphospecies $P$. densicostata and $P$. seminudata. These are comparable with the two types of Hantzpergue (1989). The P. densicostata group has marked constrictions and flared ribs, varying from depressed ( $P$. densicostata var. dorsetensis nov. and $P$. densicostata var. grandicostata nov.) through $P$. densicostata s.s. to P. densicostata var. praebaylei nov. (compressed). The P. seminudata group lacks marked constrictions and flared ribs and is divided into depressed forms ( $P$. seminudata) and compressed forms ( $P$. seminudata var. ringsteadensis nov.).

Detailed measurements have been made of rib density, but the plots of these unfortunately have little value. Heavily constricted species of Pictonia may have a marked fall in rib density between 30 and $70 \mathrm{~mm}$ diameter caused by a significant proportion of the whorl being occupied with constrictions and flared ribs, giving a U-shaped curve. Less constricted species may show a straight-line graph. However, changes in rib density can lead to constricted specimens having a straight-line graph and unconstricted specimens showing a $U$ curve. Thus, rib curves are not presented here, as they can be misleading.

Pictonia densicostata (Salfeld MS) Buckman, 1924b

Plate 7, figures 2, 5-6; Plate 8, figure 6; Plate 9, figures 1-3, 5-8; Plate 10, figures 2, 4; Text-figures 7K, N

1923 Pictonia densicostata Salfeld; Lamplugh, Kitchin and Pringle, pl. 2.

$1924 b$ Pictonia densicostata Salfeld-Kitchin-Pringle; Buckman, pl. 533.

?1927 Pictonia costigera Buckman, pl. 716.

1933 Pictonia baylei Salfeld; Arkell, pl. 34, fig. 6.

1935 Pictonia baylei Salfeld; Spath, pl. 8, fig. 4a-b.

1947b Pictonia densicostata Salfeld; Arkell, pl. 4, fig. 1.

?1989 Pictonia baylei Salfeld; Hantzpergue, pls 22a, 24a.

?1997 Pictonia densicostata Buckman; Matyja and Wierzbowski, pl. 5, figs 5-11.

2006 Pictonia densicostata Buckman; Matyja et al., fig. 5 d.
Type Material. Holotype (BGS GSM25481) from the Inconstans Bed of Ringstead Bay, Dorset; var. dorsetensis type of var. (DK31) from the Inconstans Bed of Black Head; var. praebaylei, type of var (SMC J47870) from the Inconstans Bed of Ringstead Bay; var. grandicostata, type of var. (SMC J47868) from the Inconstans Bed of Ringstead Bay.

Measurements. SMC J47867 (Pl. 9, fig. 2): D(max) $87 \mathrm{~mm}$; at $82.5 \mathrm{~mm}, 0.33,0.27,0.42$; ribs 38 at $15 \mathrm{~mm}, 39$ at $28 \mathrm{~mm}, 30$ at $60 \mathrm{~mm}, 31$ at $85 \mathrm{~mm}$. OUM J67110 (Pl. 10, fig. 4): D(max) $97 \mathrm{~mm}$ : at $97 \mathrm{~mm} ; 0.29,0.24,0.49$; ribs 35 at $63 \mathrm{~mm}, 37$ at $95 \mathrm{~mm}$.

Var. dorsetensis: DK6 (Pl. 7, figs 5-6): D(max) 75 mm, completely septate; at $75 \mathrm{~mm}, 0.32,0.30,0.44$; ribs approximately 23 at $75 \mathrm{~mm}$. DK31. Type of var. (Pl. 9, figs 5-6): D(max) $91 \mathrm{~mm}$. At $86 \mathrm{~mm} ; 0.34,-, 0.43$, ribs 30 at $58 \mathrm{~mm}, 29$ at $37 \mathrm{~mm}$. SMC J47912: $\mathrm{D}(\max ) c 155 \mathrm{~mm}, 0.6$ wh. b.c.; at $94 \mathrm{~mm}, 0.33,0.31,0.40,26$ ribs at $95 \mathrm{~mm}, 31$ at $35 \mathrm{~mm}, 34$ at $18 \mathrm{~mm}$.

Var. praebaylei: DK5: D(phg-ad) $140 \mathrm{~mm}+, \mathrm{D}(\max ) 215 \mathrm{~mm}$, close to aperture; at $200 \mathrm{~mm}, 0.31,0.24,0.48$. DK32: D(phg-ad) $106 \mathrm{~mm}, \mathrm{D}(\max ) 124 \mathrm{~mm}, 0.3 \mathrm{wh} \mathrm{bch}$; at $108 \mathrm{~mm}, 0.29,0.23$, 0.48. NHM C93792: D $(\max ) 98 \mathrm{~mm}$; at $97 \mathrm{~mm}, 0.29,0.23,0.48$; 27 ribs at $92 \mathrm{~mm}, 25$ at $60 \mathrm{~mm}$. NHM C93793 (Pl. 9, fig. 7): $\mathrm{D}$ (phg-ad) $164 \mathrm{~mm}, \mathrm{D}(\max ) 188 \mathrm{~mm}, 0.3 \mathrm{wh}$ bch; at $133 \mathrm{~mm}$, $0.27,0.19,0.49 ; 33$ ribs at $125 \mathrm{~mm}, 32$ at $100 \mathrm{~mm}, 28$ at $85 \mathrm{~mm}, 28$ at $67 \mathrm{~mm}, 31$ at $37 \mathrm{~mm}$. SMC. J47444: D(phg-juv) $65 \mathrm{~mm}, \mathrm{D}(\max ) 85 \mathrm{~mm}, 0.5 \mathrm{wh}$ bch.; at $84 \mathrm{~mm}, 0.32,0.29$, 0.48 ; ribs 29 at $80 \mathrm{~mm}, 23$ at $40 \mathrm{~mm}$. SMC J47870. Type of var. (Pl. 7, fig. 2): $\mathrm{D}$ (phg-ad) $139 \mathrm{~mm}, \mathrm{D}(\max ) 150 \mathrm{~mm}, 0.2 \mathrm{wh}$ bch.; at $104 \mathrm{~mm}, 0.30,0.25,0.45 ; 31$ ribs at $100 \mathrm{~mm}, 27$ at $60 \mathrm{~mm}$. SMC J47913 (Pl. 9, fig. 1): $\mathrm{D}(\max ) 126 \mathrm{~mm}$; at $126 \mathrm{~mm}, 0.31,0.26,0.48$; ribs 30 at $20 \mathrm{~mm}, 24$ at $45 \mathrm{~mm}$.

Var. grandicostata: SMC J47868. Type of var. (Pl. 10, fig. 2): $\mathrm{D}$ (phg-ad) $94 \mathrm{~mm}, \mathrm{D}(\max ) 127 \mathrm{~mm}, 0.75 \mathrm{wh} \mathrm{bch}$; at $101 \mathrm{~mm}$, $0.30,0.28,0.45$; ribs 25 at $75 \mathrm{~mm}, 27$ at $85 \mathrm{~mm}$.

Description. Up to diameters of $10 \mathrm{~mm}$ on the holotype, the primary ribbing is fine and strongly prorsiradiate. By $15 \mathrm{~mm}$, fine, rectiradiate, biplicate ribbing has developed. A number of secondary ribs extend down almost to the umbilical area at this diameter. The number of primary ribs is 43 at $33 \mathrm{~mm}$, with 37 at $56 \mathrm{~mm}$. Strong constrictions are present, four per whorl, each followed by a strongly raised primary rib that divides into two normally developed secondary ribs. The whorl height is slightly greater than the whorl breadth.

The holotype is more densely costate than is commonly the case in this morphospecies. Most specimens have between 35 and $40 \mathrm{rpw}$ at $30 \mathrm{~mm}$, falling to 31 to 36 per whorl at $60 \mathrm{~mm}$. In Plate 8 , figure 6 , at $25 \mathrm{~mm}$, bold primaries bifurcate into prominent secondaries, with deeply intercalated secondaries between bifid pairs. The intercalation of secondaries between bifid pairs continues to $100 \mathrm{~mm}$, when the ribbing suddenly fades. Between three and five marked constrictions per whorl are present, each followed by a prominently raised primary rib (Pl. 9, fig. 2). In the majority of specimens, the last prominent constriction and raised rib occurs between 60 and $70 \mathrm{~mm}$. Less commonly, these may continue to $80 \mathrm{~mm}$. 
Variation. Dorsetensis var. nov. is more coarsely ribbed on the middle phragmocone, with 25-30 rpw. Wide, shallow constrictions, 5 per whorl, are each followed by a markedly flared primary rib, whose bifid secondaries run strongly over the venter giving a shallow ventral collar (Pl. 7, figs 5-6). The whorl section is markedly rounded and depressed in the early whorls. Between 70 and $90 \mathrm{~mm}$ diameter this changes to a compressed, oval whorl section. The umbilical seam lies at the mid-point of the whorl side with a rapid increase in whorl height and thickness and a consequent deep umbilicus (Pl. 9, fig. 5). An excellent specimen from Hildenley, North Yorkshire, preserved in a septarian concretion, is in the BGS collection (GSM Y1679).

In praebaylei var. nov., less prominent constrictions are quite marked up to a diameter of $70 \mathrm{~mm}$, and there is no marked flaring of the subsequent primaries ( $\mathrm{Pl}$. 7, fig. 2). Normally, constrictions do not affect the secondary ribbing, although occasionally there can be some interruption (Pl. 9, fig. 3). Less coarsely ribbed forms of var. praebaylei have become smooth by $110 \mathrm{~mm}$. The ribbing fades out in characteristic irregular manner, faint, simple ribs running across the almost smooth outer phragmocone. The whorl section throughout is characteristically slim, higher than broad. Half a whorl of almost smooth, septate phragmocone is followed by a smooth body chamber. The last septum on NHM C93795 is at about $165 \mathrm{~mm}$, making the maximum diameter $240 \mathrm{~mm}$ allowing for a full whorl of body chamber.

In most specimens of $P$. densicostata, the rib style of the middle phragmocone continues that of the inner phragmacone, but in some specimens there is a marked strengthening of the primary ribbing (Pl. 10. fig. 2). Such forms may be styled grandicostata var. nov. Both specimens of var. grandicostata figured here (Pl. 9, fig. 8; Pl. 10, fig. 2) show that much denser, fainter primary ribbing sets in at $75 \mathrm{~mm}$, with only vestigial secondaries and that the shell becomes completely smooth at $90 \mathrm{~mm}$.

Stratigraphical range. P. densicostata s.s. typifies the densicostata horizon of Birkelund and Callomon (1985) (see also Matyja et al. 2006). It is absent in the baylei and normandiana horizons of Normandy (Hantzpergue 1989). Var. dorsetensis occurs in the densicostata horizon and possibly in the baylei horizon, there being a possible match with one Normandy specimen figured by Tornquist (1896, pl. 5, fig. 1), this specimen in Caen Museum, and unfortunately destroyed during the war. Var. praebaylei is common in the Inconstans Bed of Ringstead (densicostata horizon). Two specimens figured by Hantzpergue from the baylei horizon (Fm. des Calcaires coquilliers) of Normandy match it quite closely.

Remarks. Pictonia costigera (Buckman, 1927) has dense ribbing on the inner whorls similar to that of $P$. densicostata, but the type specimen clearly suffered a major injury at about $40 \mathrm{~mm}$, so that a deformed quarter of a whorl is succeeded by an untypically boldly ribbed late phragmocone and early body chamber that may be a response to the injury. The specimens from Poland figured as P. densicostata by Matyja and Wierzbowski (1997) match the holotype in their density of ribbing on the inner whorls but are less regularly constricted than British specimens and have marked ventral collars. However, in this aspect, the Polish specimens are quite close to the densely ribbed specimen from Wootton Bassett figured as P. baylei by Spath (1935) and resemble a juvenile specimen figured herein from the Inconstans Bed (Pl. 8, fig. 6). The range of rib density and whorl height/breadth ratio in var. praebaylei match those of P. baylei, and Hantzpergue (1989) included such specimens within P. baylei biosp. Morphologically, however, var. praebaylei is quite distinct, having broad, gently rounded ribbing with an oval whorl section, whereas $P$. baylei has sharp, rod-like ribbing set upon a smooth rounded-rectangular whorl section. The specimens from Zarnglaff (Czarnogłowy), Poland, figured by Dohm (1925) as P. baylei, bear stout lateral tubercles and should be grouped with Rasenia.

Pictonia seminudata (Buckman, 1924)

Plate 5, figures 4, 5; Plate 6, figure 2; Plate 8, figure 2; Plate 10, figures 1,3

\footnotetext{
?1896 Pictonia orbignyi Tornquist, 1896, pp. 29-30.

1924a Triozites seminudatus Buckman, pl. 494.

1935 Rasenia orbignyi (Tornquist) (Arkell MS).
}

Type material. Holotype (BGS GSM47535) from the Inconstans Bed of Ringstead Bay. Var. ringsteadensis. Type of var. (DK8) from the Inconstans Bed of Ringstead Bay.

Measurements. OUM J13337: $\mathrm{D}(\max )$ c. $180 \mathrm{~mm}, 0.25+$ wh. bc.; at $110 \mathrm{~mm}, 0.34,0.33,0.43$; ribs approximately 28 at $110 \mathrm{~mm}$. BGS GSM25500: $\mathrm{D}(\max ) 107 \mathrm{~mm}$; at $63 \mathrm{~mm}, 0.37$, $0.40,0.49$; at $107 \mathrm{~mm} ; 0.34,0.31,0.40 ; 28$ ribs at $17 \mathrm{~mm}, 31$ at $42 \mathrm{~mm}$. 31 at $107 \mathrm{~mm}$. BGS Zf3723: D(max) $116 \mathrm{~mm}$; At $100 \mathrm{~mm}, 0.31,0.33,0.45 ; 28$ ribs at $45 \mathrm{~mm}$. OUM J67109 (Pl. 5, fig. 4): D(phg-?ad) $149 \mathrm{~mm}$; at $149 \mathrm{~mm}, 0.35,0.33,0.46$. OUM J69569: $\mathrm{D}(\max ) 71 \mathrm{~mm}$; at $70 \mathrm{~mm}, 0.37,0.41,0.36$; 30 ribs at $70 \mathrm{~mm}$.

Var. ringsteadensis: DK8. Type of var. (Pl. 10, fig. 1): D(phgjuv) $80 \mathrm{~mm}, \mathrm{D}(\max ) 120 \mathrm{~mm}, 1 \mathrm{wh} \mathrm{bch}$; at $116 \mathrm{~mm} ; 0.31,0.23$, 0.42 ; ribs, 27 at $19 \mathrm{~mm}, 28$ at $34 \mathrm{~mm}, 31$ at $70 \mathrm{~mm}, 32$ at $110 \mathrm{~mm}$. OUM J37712 (Pl. 10, fig. 3): $\mathrm{D}(\max ) 270 \mathrm{~mm}, 0.75$ wh. bch; at $210 \mathrm{~mm}, 0.30$. -0.46 ; ribs 30 at $150 \mathrm{~m}, 30$ at $105 \mathrm{~mm}$, 15 per half whorl at $58 \mathrm{~mm}, 14$ per half whorl at $28 \mathrm{~mm}$. SMC J47448: D(phg-ad) c. $205 \mathrm{~mm}, \mathrm{D}(\max ) 245 \mathrm{~mm}, 0.4 \mathrm{wh}$ bch; at $180 \mathrm{~mm}, 0.35,0.27,0.43$; ribs 35 at $113 \mathrm{~mm}, 34$ at $78 \mathrm{~mm}$.

Description. Buckman had an unfortunate tendency to make holotypes of material that should never have been figured, and P. seminudata is no exception. One side of the holotype, which is clearly in the matrix of the Inconstans Bed of Ringstead Bay, is almost completely abraded away, and on the other, only portions of mid and outer whorl are visible. A section of ribbed whorl at about $50 \mathrm{~mm}$ diameter shows bold primaries, which trifurcate into secondaries. There is a very gentle ' $\mathrm{S}$ '-shaped curve to the ribbing. The last ribbing is visible at $140 \mathrm{~mm}$, and 
the smooth outer phragmocone does not continue the stout, depressed section of the early whorls, but becomes quite slim (at $155 \mathrm{~mm}$, height 32\%, thickness 27\%). The maximum diameter of the specimen is $260 \mathrm{~mm}$, the last septum at $200 \mathrm{~mm}$. A phase of closing up of sutures is visible at $180 \mathrm{~mm}$, but this is followed by a quarter of a whorl of normal sutures. The suture is that of mainstream Pictonia, with the lateral lobe slightly longer than the suspensive lobe, the development of a second lateral, and three small elements in the suspensive lobe.

Much better material of this oval to round-whorled, involute species is available in the OUM and BGS collections. The umbilical seam lying below the midpoint of the whorl side in the early whorls gives a somewhat cadicone appearance (Pl. 8, fig. 2). Up to $65 \mathrm{~mm}$ diameter, the primary ribs are sharp, rod-like, generally rectiradiate, but occasionally with a tendency to develop a gentle ' $\mathrm{S}$ '-shaped swing. No constrictions or flared ribs are visible on the inner whorls of most specimens (Pl. 5, fig. 5), but Pl. 8, fig. 2, a juvenile specimen, shows two marked constrictions per whorl with slightly flared ribs up to a diameter of $30 \mathrm{~mm}$. Where no constrictions are present, there is a distinct tendency to develop them, marked by the presence of regular, fainter, less raised primary ribs every quarter of a whorl, well seen in BGS GSM25500 and BGS Zf3723. At $65 \mathrm{~mm}$, the primaries become gently rounded and prorsiradiate (Pl. 5, fig. 5). At $100 \mathrm{~mm}$, the prorsiradiate primary ribs join more rectiradiate secondary ribs, three per primary (Pl. 5, fig. 4), with 12 to 13 primary ribs per half whorl. The secondaries run strongly over the venter.

Variation. Ringsteadensis var. nov. is slimmer and more planulate, but again with strong, slightly prorsiradiate primary ribs. Most primaries bifurcate into less prominent secondaries just above the mid-point of the whorl side, with additional secondaries intercalated in between bifid pairs, although occasional trifid groups of secondaries are present. The last prominent constriction is at $18 \mathrm{~mm}$ diameter in Plate 10, figure 1. NHM C77998 bears its last constriction at $30 \mathrm{~mm}$. In Plate 10, figure 3, the ribs continue to the end of the phragmocone. This feature is not present in specimen SMC J47448, which has a complete whorl of smooth phragmocone. Plate 10, figure 1 is almost complete with most of its body chamber preserved and is immature.

Stratigraphical range. This species is moderately common in the Inconstans Bed (densicostata horizon) of Ringstead Bay and occurs sporadically in the Inconstans Bed of Swindon (J.H. Callomon Collection).

Remarks. Closely allied specimens from Normandy were described as P. thurmanni (Contejean) by Hantzpergue (1989). Schweigert and Callomon (1997) noted that the use of this species in this context was inadvisable, P. thurmanni being a submediterranean species. The specimens in question were referred to $P$. normandiana Tornquist by Schweigert and Callomon (1997). The differences between $P$. seminudata and P. normandiana sensu Schweigert and Callomon were spelt out by Hantzpergue (1989), noting that $P$. seminudata is more densely ribbed in the inner whorls, and is bigger $(250 \mathrm{~mm}+)$. P. seminudata is more involute in the early whorls, and the dense secondary ribbing is much less prominent that the primary ribbing. Primaries and secondaries are equally as bold in P. normandiana. $P$. seminudata and $P$. normandiana have similar whorl sections, but $P$. normandiana has bolder secondary ribbing.

Whilst surveying the Sedgwick Museum collection in 1935, Arkell attached the manuscript name Rasenia orbignyi (Tornquist) to the specimen SMC J47448, here included in var. ringsteadensis. Arkell's difficulty was that the absence of constrictions and flared primary ribs on the middle whorls of this specimen made allocation to Pictonia difficult. It is now clear that such forms of Pictonia without constrictions and flared ribs are common in the Inconstans Bed fauna. These are grouped here in P. seminudata. Attribution to Rasenia is incorrect. The excellent preservation of specimen DK8 (Pl. 10, fig. 1), collected from the same horizon and locality as SMC J47448, shows that on the innermost whorls of var. ringsteadensis, the primary ribs do not show the forward-projecting bullae characteristic of Rasenia. The bold, sharp primary ribbing, high bifurcation points, the less prominent, bifid secondaries and the fading of the secondaries over the venter are all typical of Pictonia seminudata. The dimensions of var. ringsteadensis are close to those of the specimen from Normandy described as P. orbignyi by Tornquist (1896), but Tornquist did not figure his specimen that, being in Caen Museum, was presumably destroyed during the war.

\section{Genus MICROBIPLICES Arkell, 1936}

Type species. Ammonites microbiplex Quenstedt, 1887-88 (p. 876, pl. 94, fig. 36). Holotype from the Bimammatum Zone of Lochengrundle, Swabian Alb.

Remarks. Microbiplices comprises small (c. $100 \mathrm{~mm}$ ) to very small (c. $40 \mathrm{~mm})$ microconch aulacostephanids with coarse, biplicate ribbing and lappets. Secondary ribbing becomes visible below the umbilical seam of the uncoiling body chamber. Quenstedt's drawing was refigured by Arkell (1936, pl. C, figs 6a-e). One feature of the drawing difficult to understand is that the artist has drawn the specimen as completely septate, but in the cross-section, septae are not shown on the outer whorl. As the outer whorl is uncoiling and appears to be body chamber, drawing of some of the septae here may have been a misrepresentation by the artist.

Arkell (1947a, p. 378) commented that Microbiplices had a close affinity with Prorasenia. Schweigert and Callomon (1997) proposed that all Pseudocordata and Baylei Zone aulacostephanid microconchs should be incorporated in the latter. However, it seems best to keep the two genera separate (Matyja and Wierzbowski 2003). Microbiplices is used here for microconchs having biplicate or 
triplicate ribbing on the phragmocone, with bi- or trifurcation points fairly high on the whorl side. Prorasenia is used for later forms that have swollen, prorsiradiate primary ribs, with trifurcation points on the phragmocone well below the mid-point of the whorl side, allowing the secondary ribbing to be seen in the umbilicus well before the development of the body chamber.

Microbiplices anglicus Arkell, 1947

Plate 1, figures 6-8; Plate 2, figures 7-8; Plate 4, figure 6

1947a Microbiplices anglicus Arkell, p. 348, pl. 76, figs $6 \mathrm{a}, \mathrm{b}, 7 \mathrm{a}, \mathrm{b}$.

?1972 Perisphinctes (Microbiplices) anglicus Arkell; Malinowska, p. 26, pl. 9, fig. 4.

?1975 Microbiplices sp. Brochwicz-Lewinski and Rożak, pl. 1 , fig. 1 .

1986 Microbiplices aff. anglicus Arkell; Wright, fig. 6H.

1998 Microbiplices aff. anglicus Arkell; Wright, fig. 7B.

Type material. Holotype (BGS GSM30627) from the Sandsfoot Grit of Weymouth.

Measurements. DC61 (Pl. 1, fig. 8): (D(phg-ad) $24 \mathrm{~mm}, \mathrm{D}(\max )$ $40 \mathrm{~mm}, 0.8$ wh bch, with terminal constriction, swollen final rib and lappets: at $39 \mathrm{~mm}, 0.30,0.30,0.44 ; 20$ ribs on the last three quarters of a whorl. DC97 (figured, Wright, 1998, fig. 7B): D(phg?ad) $18 \mathrm{~mm}, \mathrm{D}(\max ) 28 \mathrm{~mm}, 0.75 \mathrm{wh}$ bch; at $28 \mathrm{~mm}, 0.34,-$, 0.45. RHUL ic376d: D(phg-?ad) $22 \mathrm{~mm}, \mathrm{D}(\max ) 34 \mathrm{~mm}, 0.75 \mathrm{wh}$ bch. RHUL ic377 (Pl. 4, fig. 6): D(phg-?ad) $20 \mathrm{~mm}, \mathrm{D}(\max )$ $30 \mathrm{~mm}, 0.75 \mathrm{wh}$ bch; at $29 \mathrm{~mm}, 0.32,0.37,0.52$.

Description. When the ribbing is first visible at $12 \mathrm{~mm}$, the primaries are markedly prorsiradiate, bifurcating into rectiradiate secondaries with every third rib trifurcating. At $16 \mathrm{~mm}$, bifurcation is the norm, the bifurcation points being just visible in the umbilicus (Pl. 4, fig. 6). The umbilicus is very deep, with the whorl breadth increasing very rapidly, so that at $15 \mathrm{~mm}$, the whorl breadth is twice the whorl height. On the body chamber, the slightly prorsiradiate primaries average 24 per whorl, varying from 18 to $28 \mathrm{rpw}$. The slightly less bold secondaries bifurcate with extreme regularity, with a smooth band along the venter, this band not being present on the last third of a whorl, where the ventral ribbing is strong ( $\mathrm{Pl}$. 1, fig. 6; Pl. 2, fig. 7). The whorl section is slightly broader than high. The body chamber uncoils, clearly revealing the bifurcation points just below the umbilical seam (Pl. 4, fig. 6). The average maximum diameter of the 10 specimens that are complete with the aperture is $49 \mathrm{~mm}$, the holotype being almost complete at $43 \mathrm{~mm}$. Three specimens, DC152, NHM C19475 and NHM C82014, are unusual in having maximum diameters between 60 and $66.5 \mathrm{~mm}$. With more material, it may be possibly to separate off the larger forms as a separate species.

Stratigraphical range. M. anglicus is abundant in the Pseudocordata Subzone and rare in the underlying Pseudoyo Subzone.
Remarks. Variants occur with slightly denser ribbing (Pl. 1, fig. 8; Pl. 2, figs 7-8; Sykes and Callomon, 1979, pl. 121, figs 14-15), resembling M. microbiplex (Quenstedt), holotype refigured by Arkell (1936, pl. C, figs 6a-c). This has a slightly depressed whorl section on the body chamber, but this is rare, and most specimens that have been figured (e.g. Dorn, 1930, pl. 7, figs 4a, b) show a round whorl section. The specimen figured by Brochwicz-Lewinski and Rozak (1975) from Poland belongs to the larger sized group, and typically has denser ribbing close to the aperture. It came from the Grossouvrei Subzone (?Caledonica Subzone). Malinowska's (1972) specimen is quite close to M. anglicus, although lacking the bold, sharp ribbing on the inner whorls. Its age is younger than given by Malinowska, probably lower Bimmammatum Zone (= Pseudocordata Zone) (Wierzbowski, pers. comm. 2007).

\section{Genus PRORASENIA Schindewolf, 1925}

Type species. Prorasenia quenstedti Schindewolf, 1925, nom. nov. for Ammonites biplex bifurcatus Quenstedt, 1887-88, pl. 101, fig. 14 , from the White Jura Beta (uppermost Bimmamatum Zone + Planula Zone $=$ Baylei Zone) of Grat bei Laufen in the Swabian Alb.

Remarks. Schindewolf (1925) did not designate a holotype for his new species, listing a type series of specimens including the one figured by Quenstedt and two in his own collection. Subsequently, he figured a specimen from the White Jura Beta of Beuren in the Swabian Alb as lectotype (Schindewolf 1926, pl. 19, fig. 1). As defined by Schindewolf (1925, 1926), Prorasenia comprises small (c. $35 \mathrm{~mm}$ ) microconch aulacostephanids with triplicate Rasenia-like ribbing on the inner whorls. On the outer whorl, the ribs become swollen, sharp and biplicate. Secondary ribbing is visible in the umbilicus from a very early stage.

Use of this taxon for Sub-Boreal and Boreal forms after Spath (1935) must be provisional. Prorasenia was introduced for forms originating in Sub-Mediterranean areas where the assumed macroconch counterpart is not at all typical of Sub-Boreal Pictonia. We are probably dealing in Britain with microconch aulacostephanids which homeomorph Sub-Mediterranean forms rather than forms that have a direct genetic connection.

Prorasenia sp.

Plate 1, figure 9; Plate 7, figure 8

Measurements. NHM C75301 (Pl. 1, fig. 9). D(max) 33.5; 0.3 wh bc. At $33.5,0.31,0.42,0.45 .17$ ribs at $33.5 \mathrm{~mm}, 15$ ribs at $19 \mathrm{~mm}$. 
Description. Specimen NHM C75301, collected from the characteristic iron-shot micritic oolite of the Osmington Mills Ironstone of the Fleet Lagoon by Dr N.H. Morris (Pl. 1, fig. 9) shows the characters well. The test is preserved, so the exact position of the last septum is not certain, but the specimen is characteristic of a microconch adult with one third of a whorl of body chamber. The primary ribbing is bold, coarse and strongly raised, prorsiradiate up to $15 \mathrm{~mm}$ diameter and then rectiradiate. The secondaries trifurcate regularly up to $23 \mathrm{~mm}$, followed by a quarter of a whorl of alternations of biplicate and triplicate secondaries and then biplicate on the body chamber. On NHM C75302 (Pl. 7, fig. 8), solely biplicate ribbing sets in earlier, at $17 \mathrm{~mm}$. On NHM C82034, alternations of biplicate and triplicate secondaries are seen to $19 \mathrm{~mm}$, the maximum diameter preserved. The secondaries are normally hidden by the overlapping whorl, only appearing beneath the uncoiling body chamber at $20 \mathrm{~mm}$ (Pl. 7, fig. 8). The whorl section is very depressed in the early whorls, with the whorl breadth twice the whorl height, the whorl section becoming more rounded on the body chamber.

Stratigraphical range. This boldly ribbed, depressed form of Prorasenia is characteristic only of the Evoluta Subzone.

Remarks. The specimens discussed here retain the high bifurcation/trifurcation points of Microbiplices, with secondaries only becoming visible beneath the uncoiling body chamber. However, they undoutably represent an early form of Prorasenia, with swollen ribs on the inner whorls (similar to P. bowerbanki), and they do not show the presence of the thin primary ribs characteristic of Microbiplices. The specimens illustrated as Microbiplices/ Prorasenia transitional form by Matyja et al. (2006) have ribbing characteristic of Microbiplices on the inner whorls up to 15-20 mm diameter. This feature is not shown in the present specimens, which are thus included in Prorasenia.

Prorasenia bowerbanki Spath, 1935

Plate 7, figure 9; Plate 9, figure 4

1935 Prorasenia bowerbanki Spath, p. 43, pl. 14, figs $3 a, b$.

1997 Prorasenia bowerbanki Spath; Matyja and Wierzbowski, pl. 5, figs 12, 13.

2006 Prorasenia bowerbanki Spath; Matyja et al., fig. 4j.

Type material. Holotype (NHM 24712) from the 'Lower Kimmeridge Clay' of Wootton Bassett.

Measurements. SF1 (Pl. 7, fig. 9): $\mathrm{D}(\max ) 34 \mathrm{~mm}$, complete with aperture and lappets partially preserved; test partly present obscuring sutures; at $34 \mathrm{~mm}, 0.30,0.33,0.47$ : ribs 22 at $34 \mathrm{~mm}$, 20 at $17.5 \mathrm{~mm}, 20$ at $14 \mathrm{~mm}, 24$ at $8 \mathrm{~mm}$. DK35 (Pl. 9, fig. 4): $\mathrm{D}$ (phg-ad) $23 \mathrm{~mm}+, \mathrm{D}(\max )$ c. $42 \mathrm{~mm}$, aperture partially preserved; at $23 \mathrm{~mm}, 0.33,0.34,0.46$; ribs 9 per half whorl at $23 \mathrm{~mm}$.
Description. SF1 shows the characters of the species very well (Pl. 7, fig. 9). When the primary ribbing is first seen at $8 \mathrm{~mm}$ diameter, it is strongly prorsiradiate, and trifurcation into secondaries is clearly visible beneath the overlapping whorl. At $15 \mathrm{~mm}$, the ribbing becomes only slightly prorsiradiate. The primary ribs are markedly raised just below the trifurcation points. At $17 \mathrm{~mm}$, the first bifid pairs are present, with no trifurcation after $23 \mathrm{~mm}$, and less raised primaries. Simple ribs are present close to the aperture. The whorl height is about equal to the whorl breadth. The fragmentary DK35 (Pl. 9, fig. 4) has very similar inner whorls but is mature at a larger diameter (cf. $42 \mathrm{~mm}$ as against $34 \mathrm{~mm}$ ).

Stratigraphical range. The holotype of P. bowerbanki (NHM 24712) came from Wootton Bassett, Wiltshire, horizon not recorded. Specimens from Staffin, on the Isle of Skye, show that P. bowerbanki typifies principally the flodigarriensis horizon, coming just above the Oxfordian/Kimmeridgian boundary (Matyja et al. 2006, fig. 4), and probably continuing up into the densicostata horizon. Thus, at South Ferriby, it is likely that the Oxytoma Cementstone (which yielded the specimen figured in Pl. 7, fig. 9) represents the flodigarriensis horizon, slightly older that the densicostata horizon of the Inconstans Bed and that this very distinctive species is a good marker for the base of the Kimmeridgian.

Remarks. The change from the higher bifurcation/trifurcation points of Microbiplices to bifurcation/trifurcation points below the mid-point of the whorl side in $P$. bowerbanki is very striking, the secondaries being visible below the umbilical seam at $8 \mathrm{~mm}$ diameter. In the specimens figured by Matyja and Wierzbowski (1997), trifurcate secondaries become visible in the umbilicus at a much later stage in the coiling than in the holotype or SF1, suggesting that the Polish specimens are an early variety transitional from Microbiplices.

Prorasenia cf. hardyi Spath, 1935

Plate 8, figures 7, 8; Plate 10, figures 5, 6

1935 Prorasenia hardyi Spath, pl.11, fig. 3a, b, pl. 15, fig. $5 \mathrm{a}, \mathrm{b}$

1947b Prorasenia sp. Arkell, pl. 4, fig. 2.

1978 Prorasenia aff. bathyschista (Koerner); Wierzbowski, p. 3 , fig. 8.

1997 Prorasenia cf. hardyi Spath; Schweigert and Callomon, pl. 7, fig. 10.

2006 Prorasenia hardyi Spath; Matyja et al., fig. 4i.

Type material. Holotype (NHM 89045) from the 'Lower Kimmeridge Clay' of Wootton Bassett.

Measurements. DK33 (Pl. 10, fig. 6): D(phg-ad) $18 \mathrm{~mm}, \mathrm{D}(\max )$ $27 \mathrm{~mm}, 0.7 \mathrm{wh} \mathrm{bch}$, aperture not present; at $26 \mathrm{~mm}, 0.33,0.38$, 0.46 ; 13 ribs per half whorl at $26 \mathrm{~mm}$. DK34 (Pl. 8, fig. 8): $\mathrm{D}$ (phg-ad) $22 \mathrm{~mm}, \mathrm{D}(\max ) 25 \mathrm{~mm}, 0.3 \mathrm{wh}$ bch; at $20 \mathrm{~mm}$, 
$0.38,0.53,0.43 ; 20$ ribs at $25 \mathrm{~mm}, 17$ ribs at $11 \mathrm{~mm}$. SMC J47351 (Pl. 10, fig. 5): D(phg-ad) $20 \mathrm{~mm}, \mathrm{D}(\max ) 30 \mathrm{~mm}$, $0.75 \mathrm{wh}$ bch, aperture and lappet partly preserved; at $30 \mathrm{~mm}$, $0.32,0.37,0.45 ; 26$ ribs at $30 \mathrm{~mm}, 26$ at $21 \mathrm{~mm}, 26$ at $8 \mathrm{~mm}$.

Description. The specimens have the whorl breadth substantially greater than the whorl height. The primary ribs are markedly prorsiradiate in the umbilicus and still prorsiradiate on the body chamber. They are raised where they join the secondaries below the mid-point of the whorl side. The secondaries run in a rectiradiate direction across the venter, frequently interrupted by a near-smooth band along the centre line. Up to a diameter of $13 \mathrm{~mm}$, each primary trifurcates (Pl. 8, fig. 7). Thereafter, every third primary rib trifurcates and the others bifurcate up to a point a quarter of a whorl into the body chamber, when bifurcation is the norm ( $\mathrm{Pl} .10$, fig. 6). The trifurcation points are clearly visible in the umbilicus from a diameter of $12 \mathrm{~mm}$ onwards.

Stratigraphical range. The holotype of P. hardyi (NHM 89045) was collected from the Lower Kimmeridge Clay of Wootton Bassett (Spath 1935), but the exact horizon is uncertain. Specimens resembling this species are quite common in the south Dorset Inconstans Bed, typifying the densicostata horizon. On Skye, P. hardyi continues up into the Normandiana Subzone of the Baylei Zone (Matyja et al. 2006).

Remarks. The Inconstans Bed specimens have a rib density and maximum size matching those of the holotype (Spath 1935, pl. 15, fig. 5a, b). However, they are more depressed and evolute than the holotype, and may not be cospecific. In addition, the specimens figured in Plate 10 do not show the swollen primary ribs typical of the inner whorls of $P$. hardyi. Such thin primary ribbing is normally typical of Microbiplices; however, the depressed body chamber and early appearance of secondary ribs in the umbilicus at only $12 \mathrm{~mm}$ diameter are both typical of Prorasenia. The Polish specimen figured by Wierzbowski (1978, pl. 3, fig. 8) has the coarse early ribbing but is nearly as evolute as the Dorset specimens. The specimen from southern Germany figured as $P$. cf. hardyi by Schweigert and Callomon (1997), is more coarsely ribbed and more involute than the Dorset specimens and is thus closer to the holotype.

\section{VARIATION IN THE SUTURE OF RINGSTEADIA AND PICTONIA}

From its beginnings as Decipia and Pseudarisphinctes at the beginning of the Late Oxfordian, through its substantial development as Ringsteadia, and into Kimmeridgian Pictonia and Rasenia, the family Aulacostephanidae maintained a characteristic suture pattern that helps separate it from the subfamily Perisphinctinae. In the latter subfamily, the second lateral lobe is usually set at an angle of some 30 degrees to the first lateral lobe, so that the second lateral saddle widens out in a forwards direction, the two lateral lobes pinching together at its neck. In all aulacostephanids, the second lateral lobe is an exact, miniature copy of the first lateral lobe, set almost exactly parallel to it, so that the second lateral saddle maintains its width along its length. This basic pattern is maintained regardless of involute or evolute coiling, coarse or fine ribbing, complexity of sutural development, and comparative length of external, lateral and suspensive lobes. Study of the specimens of Ringsteadia collected from the Keypoint site, South Marston (Pseudoyo Subzone) shows that they can be arranged into three equal-sized groups based on suture:

Group 1 (Text-fig. 7G-I) has a complex suture, with an elaborate, deeply incised first lateral lobe and a similar, slightly smaller second lateral lobe, and an extremely elaborate, backwards projecting suspensive lobe. The suspensive lobe has six auxiliary elements projecting in an acute, radial direction at about 20 degrees from the radial line. The second of these six auxiliaries is the longest and projects radially almost to meet the second lateral lobe.

Group 2 (Text-fig. 7A, C-E, J) has a moderately to elaborately complex suture, usually with smaller, less elaborately developed first and second lateral lobes and a backwards projecting suspensive lobe about equal in length to the outer lobes. The suspensive lobe again contains six auxiliaries, moderately or elaborately developed and projecting at about 45 degrees to the radial line. Although the second auxiliary is again the longest, it ends a considerable distance from the second lateral lobe.

Group 3 (Text-fig. 7B, F) has simple sutures, with short, stocky, only moderately incised first and second lateral lobes, and a long, radially directed suspensive lobe with six small auxiliaries that are either spirally directed or run at 20 or 30 degrees to the spiral direction. This feature was described by Arkell (1935, p. xxxii) as the auxiliaries swinging round into line with the external and lateral lobes to form morphologically not only a 'second' but a 'third' and 'fourth lateral'.

There is no marked tendency for one suture pattern to occur preferentially within one particular morphospecies rather than another. The Group 1 style suture is developed throughout R. pseudoyo, R. brandesi, R. pseudocordata and is very common in $R$. marstonensis and $R$. bassettensis. Group 2 is equally developed throughout the same morphospecies. Group 3 again occurs in $R$. pseudoyo, R. brandesi and R. pseudocordata, although there is the possibility that it may be more common in the smooth, evolute varieties of $R$. marstonensis. This similarity in range of suture pattern throughout all these morphospecies is good evidence that we are dealing with one vary variable biospecies. 
Evoluta Subzone Ringsteadia have a much less variable suture pattern. The sutures of all specimens I have examined can be accommodated easily in Group 2 (Textfig. 7L-M). The suture is thus only moderately incised, with short lobes, and the second lateral lobe precisely matching the first in spiral orientation. The auxiliary elements project at about 45 degrees to this direction, the suspensive lobe usually being shorter than the lateral or external lobes, although in one specimen it is the longest.

Ringsteadia is not the only perisphinctoid to show variation in its suture. Glowniak (2002) has reported considerable variation within the suture patterns of Middle Oxfordian Kranaosphinctes. Arkell (1939, p. vii) noted that the complexity of suture pattern and variation in the proportionate length of lobes in Arisphinctes varies considerably.

Most Pictonia have quite a simple suture (Text-fig. 7K, $\mathrm{N})$. Lobes are of moderate length, rarely deeply incised, so that they are usually quite stocky, and the septae widely separated. The second lateral lobe is usually orientated parallel to the first, although in occasional specimens it may be orientated at 15 degrees or 20 degrees to it, directed slightly radially. The suspensive lobe is directed obliquely, variable in length, rarely with more than four auxiliaries visible. Slightly more complex sutures are occasionally present (Text-fig. 7K).

\section{RECORDS OF RINGSTEADIA, PICTONIA, AND THEIR MICROCONCHS FROM OUTSIDE ENGLAND AND NORTHERN FRANCE}

\section{Records from the Boreal and Sub-Boreal Provinces}

Ringsteadia and Microbiplices are abundant at Staffin in the Isle of Skye (Matyja et al. 2006). Northwards, there do not appear to be any records of Ringsteadia in Greenland or Spitzbergen (Svalbard), further into the Boreal Province. However, Sub-Boreal Ringsteadia extended eastwards into northern Germany, Salfeld (1917) recording $R$. brandesi and $R$. frequens from the upper marly beds of the 'Korallenoolith' of the Hannover region (Text-fig. 1). The specimens of Ringsteadia collected by Dohm (1925) from Zarnglaff, now Czarnogłowy in western Poland, appear to be a local, endemic group, as they fit precisely neither Sub-Boreal nor Sub-Mediterranean species. However, several species of Ringsteadia and Microbiplices, particularly $R$. brandesi and $R$. pseudocordata found near Krakow (Siemiradski Collection, Krakow; taxonomic revision by Głowniak and Wierzbowski 2007) have been recorded from south-central Poland and were listed above. Malinowska (1991) figured Ringsteadia spp. from Central Poland. Ringsteadia close to $R$. brandesi has been figured from the Unzha River Basin, North-east of Moscow, by Rogov and Kiselev (2007). Mesezhnikov (1988) has figured Ringsteadia close to R. evoluta from the Ural River Basin in Siberia.

Pictonia and Prorasenia are abundant again at Staffin (Matyja et al. 2006), and at least two species of Pictonia reached eastern Greenland (Sykes and Surlyk 1976; Birkelund and Callomon 1985). However, northwards in Svalbard, only Amoeboceras is known (A. Wierzbowski, pers. comm. 2003). Eastwards, it seems likely that Pictonia was unable to progress from northern France into Germany; Early Kimmeridgian strata seem to be present, but there are no records of these Early Kimmeridgian ammonites from the area (Arkell 1956, p. 138). However, the range of Pictonia does extend northeastwards to the Kheta River Basin in Siberia, from where Mesezhnikov (1969) figured P. involuta Mesezhnikov and P. ronkinae Mesezhnikov, both species displaying most of the characteristics of mainstream Pictonia, but being more involute than western forms.

\section{Records from the Sub-Mediterranean Province}

It is clear that Sub-Boreal Ringsteadia made its way at times into the Sub-Mediterranean Province. $R$. cf pseudoyo, R. brandesi and R. pseudocordata (Pseudocordata Subzone) all have been found in the Czestochowa-Krakow area of southern Poland, and R. evoluta (Evoluta Subzone) has been recorded from the Swabian Alps through to southern Poland. However, forms endemic to the SubMediterranean Province rapidly evolved:

Ringsteadia salfeldi Dorn has been recorded by numerous authors from the Hypselum Subzone of the SubMediterrannean Province [Brochwicz-Lewinski (1976), Gygy (1995), Schairer (1989), Schweigert and Callomon (1997)]. The lectotype (Dorn 1925, pl. 22, fig. 3, designated by Gygy 1995) has strong, prorsiradiate, biplicate or triplicate, moderately projected ribbing without the sheaves of secondaries characteristic of Sub-Boreal Ringsteadia. Strong, rectiradiate simple ribs interrupt the ribbing every half whorl. $R$. salfeldi is thus an early form of Ringsteadia, equivalent in age to the Caledonica or Pseudoyo subzone faunas of the Sub-Boreal Province, and developing its own unique features.

Ringsteadia involuta (Quenstedt), as figured by Rozak and Brochwicz-Lewinski (1978) from the Hypselum Subzone (Pseudocordata Zone) of Czestochowa in Poland, has the appearance of an evolute $R$. brandesi, with typical fading of the ribbing on the mid whorl side, but is more densely ribbed.

Ringsteadia submediterranea Wierzbowski, as figured by Wierzbowski (1978, pl. 3, figs 1-3) is probably earliest Kimmeridgian in age. Its degree of involution matches 
R. pseudoyo exactly, but the ribbing is much finer and more delicate than anything seen in the Sub-Boreal province. Vineta streichensis (Oppel) (Schweigert and Callomon 1997, pl. 7, fig. 11) (?early Baylei Zone) is very close to R. submediterranea.

Ringsteadia limosa (Quenstedt), as figured by Wierzbowski (1970, 1978), comes from beds equivalent in age to those of the lower Baylei Zone. The cross-section and coarse, blunt ribbing match those of $R$. evoluta well, but the primaries and secondaries are more clearly differentiated, with distinct bifurcation/trifurcation points. R. limo$s a$ as interpreted by Schneid (1940, pl. 14, fig. 5), is rather different, with forward-swept ribbing interrupted by a spiral smooth band on the middle of the whorl side.

Ringsteadia flexuoides occurs throughout the Polish Planula Zone, possibly extending down into the Bimammatum Zone (Wierzbowski 1970). Its stratigraphical range thus covers the whole Baylei Zone of the SubBoreal scheme. It is more finely ribbed than $R$. limosa, with clear distinction in the early whorls into fine, rod-like primaries and secondaries with dischizotomous separation of the secondaries and forward-swept ribbing. Schweigert and Callomon (1997) recorded R. flexuoides from the Bimammatum Zone of the Swabian Alb (probably uppermost Oxfordian).

Four species of Pictonia are known, none at all close to Sub-Boreal forms. P. (Pictonia) densicostata (Matyja and Wierzbowski, 1997, pl. 5, figs 5-11) is much less regularly constricted than is typical in the forms from England figured here but is still closely related. Pictonia kuiaviensis Matyja and Wierzbowski (2002, pl. 1 figs 4-11) is a younger form transitional between Pictonia and Rasenia. Pictonia perisphinctoides (Wegele) and P. praeperisphinctoides Schweigert and Callomon figured by Schweigert and Callomon (1997) from the Sub-Mediterranean Province are much less heavily constricted and flared than mainstream Sub-Boreal forms.

\section{CONCLUSIONS}

All sections of Upper Oxfordian strata in southern England show a gradual, often step by step, deepening of facies, from shallow water sands and ooidal ironstones into deeper water clays and marls. At many localities in England, Oxfordian/Kimmeridgian boundary strata are missing, an erosion surface separating Early Kimmeridgian strata from Late Oxfordian strata. The major transgression $\mathrm{km} 1$ of the Early Kimmeridgian (Taylor et al. 2001) saw the temporary establishment of shallow, muddy, clastic-dominated seas with an abundant shallow water bivalve/brachiopod fauna (Inconstans Bed) throughout shelf areas of England. The effect of this regression/transgression was to leave a gap in the succes- sion marked by the break between ammonite faunas dominated by the involute Ringsteadia and those dominated by the evolute, constricted Pictonia (Text-fig. 8C, D). This break was chosen by all the early workers as defining the Oxfordian/Kimmeridgian boundary. However, confused by the occurrence of the Early Kimmeridgian forms of Ringsteadia listed above, continental geologists have generally taken the replacement of the ammonite that co-existed with late Ringsteadia, Idoceras planula, by Sutneria, at the junction of the Planula and Platynota zones, as marking the Oxfordian/Kimmeridgian boundary. Only recently has it become apparent that the boundary has been taken at a substantially higher level on the continent than it has been taken in England (Matyja and Wierzbowski 1994, 1997). A discussion of the latest situation as regards correlation of the Boreal/SubBoreal and Mediterranean/SubMediterranean Oxfordian/Kimmeridgian boundary sequences is given in Matyja et al. (2006).

With the advent of precise absolute dating, sequence stratigraphy, magnetostratigraphy and chemostratigraphy, it has become increasingly necessary to define the Oxfordian/Kimmeridgian stage boundary at one synchronous level throughout Europe (Wierzbowski et al. 2006). The preferred option of these authors is to take it at the base of the Baylei Zone, and this is the option taken in the definitive papers of Gradstein and Ogg (2004) and Gradstein et al. 2004. Callomon (2004) has argued strongly that the Kimmeridgian GSSP should be situated in south Dorset. However, in the author's opinion, none of the Dorset exposures recommended by Callomon (2004) as suitable sites for a GSSP are satisfactory. The fossiliferous shelly limestone of the Inconstans Bed of Ringstead Bay, which yielded the vast majority of the specimens of Pictonia described here, is now covered by sea defences and beach shingle. All other Inconstans Bed exposures in south Dorset are poor and yield only sporadic ammonites. In addition, a succession such as that in south Dorset containing a substantial non-sequence, and in places an unconformity, beneath the earliest Kimmeridgian, although excellent for defining a sequence boundary, is entirely unsuited for defining a stage boundary. Walsh et al. (2004, p. 209) note that 'unconformities have long been rejected as suitable horizons for golden spikes' (i.e. GSSP's) because correlative evidence is only available on one side of the spikes. The proposal of Matyja et al. (2006) is to draw the Oxfordian/Kimmeridgian boundary beneath the flodigarriensis horizon of the Baylei Zone at Staffin in Skye in a succession that has continuous sedimentation across the Rosenkrantzi/Bauhini and Pseudocordata/Baylei zone boundaries. Further work will be necessary to decide precisely where this level lies within the Sub-Mediterranean Bimammatum Zone (A. Wierzbowski, pers. comm. 2006). 
Acknowledgements. Professor J.H. Callomon kindly loaned his collection of uppermost Oxfordian ammonites, gave much valuable advice and considerably improved the manuscript in his refereeing of it. Dr B.M. Cox and Professor A. Wierzbowski also made substantial improvements during their refereeing. Mr C. Griffiths loaned his collection of Oxfordian/Kimmeridgian ammonites. Thanks are due to the respective curators at the Natural History Museum London, British Geological Survey, Oxford University Museum, Sedgwick Museum Cambridge and Devizes Museum for allowing the author to study and photograph ammonites in their care. Thanks are also due to the staff at Mowlem Ltd for allowing access to the Keypoint site near Swindon, and for making available specimens collected by workers there. Mr J. McGrow assisted in the preparation of the figures.

Editor. Elizabeth Harper

\section{REFERENCES}

ARKELL, W. J. 1933. The Jurassic system in Great Britain. Clarendon Press, Oxford, viii+681 pp.

- 1935. A monograph of the ammonites of the English Corallian Beds, part 1. Palaeontographical Society Monograph, 88, i-xxxii, 1-30.

-1936. A monograph of the ammonites of the English Corallian Beds, part 2. Palaeontographical Society Monograph, 89, xxxiii-xlvi, 31-42.

- 1937. Report on ammonites collected at Long Stanton, Cambs., and the age of the Ampthill Clay. Summary of Progress of the Geological Survey of Great Britain and the Museum of Practical Geology for the year, 1935, 2, 64-88.

1939. A monograph of the ammonites of the English Corallian Beds. part 5. Palaeontographical Society Monograph, 92, lv-lxiv, 105-190.

-1940. A monograph of the ammonites of the English Corallian Beds, part 6. Palaeontographical Society Monograph, 94, lxv-lxxii, 191-216.

- 1947a. A monograph of the ammonites of the English Corallian Beds, part 13. Palaeontographical Society Monograph, 101, 351-378.

-1947b. The Geology of the Country around Weymouth, Swanage, Corfe and Lulworth. Memoir of the Geological Survey of Great Britain, England and Wales, 386 pp.

- 1948. A monograph of the ammonites of the English Corallian Beds, part 14. Palaeontographical Society Monograph, 102, i-v, 379-420.

— 1956. Jurassic geology of the world. Oliver \& Boyd, Edinburgh and London, xiv+806 pp.

- KUMMEL, B. and WRIGHT, C. W. 1957. Mesozoic Ammonoidea. L80-L490. In MOORE, R. C. (ed.). Treatise on invertebrate Palaeontology, Part L, Mollusca 4, Cephalopoda - Ammonoidea. Geological Society of America, Boulder, Colorado and University of Kansas Press, Kansas, xxii+L1L490.

BAYLE, E. 1878. Fossiles principaux des terraines. Service de la Carte géologique détaillée. Explication de la Carte géologique détaillée, 4, Atlas, part 1, 158 pls.
BIRKELUND, T. and CALlOMON, J. H. 1985. The Kimmeridgian ammonite faunas of Milne Land, central east Greenland. Bulletin Grønlands Geologiske Undersøgelse, 153, 56 pp.

BLAKE, J. F. and HUDLESTON, W. H. 1877. On the Corallian rocks of England. Quarterly Journal of the Geological Society of London, 33, 260-405.

BRISTOW, C. R., COX, B. M., WOODS, M. A., PRUDDEN, H. C., SOLE, D., EDMUNDS, M. and CALLOMON, J. H. 1991. The geology of the A303 trunk road between Wincanton, Somerset and Mere, Wiltshire. Proceedings of the Dorset Natural History and Archaeological Society, $113,139-143$.

BROCHWICZ-LEWINSKI, W. 1976. Oxfordian of the Czestochowa Area. I. Biostratigraphy. Bulletin de l'Académie Polonaise des Sciences, Série des Sciences de la Terre, 24, 37-46.

— and ROZAK, Z. 1975. Time changes of Oxfordian ammonite fauna of the Polish Jura Chain; some reflections. Bulletin de l'Académie Polonaise des Sciences, Série des Sciences de la Terre, 22, 113-125.

BROOKFIELD, M. E. 1978. The lithostratigraphy of the upper Oxfordian and lower Kimmeridgian Beds of south Dorset, England. Proceedings of the Geologists' Association, 89, 1-32.

BUCKMAN, S. S. 1919-30. Type Ammonites. Published by the author. London and Thame.

1921. Type Ammonites Part 27, pp. 41-42.

1924a. Type Ammonites Part 46, pp. 21-28.

1924b. Type Ammonites Part 49, pp. 41-48.

- 1925a. Type Ammonites Part 51, pp. 57-64.

-1925b. Type Ammonites Part 53, pls 528, 577-592.

1926. Type Ammonites Part 60, pp. 29-36.

1927. Type Ammonites Part 63, pls 135, 157, 706-717.

CAllomon, J. H. 1963. Sexual dimorphism in Jurassic ammonites. Transactions of the Leicester Literary and Philosophical Society, 57, $36 \mathrm{pp}$.

- 1969. Dimorphism in Jurassic Ammonites. 111-125. In WESTERMANN, G. E. G. (ed.). Sexual dimorphism in fossil Metazoa and taxonomic implications. E. Schweitzerbart'sche Verlagsbuchhandlung, Stuttgart, iv $+250 \mathrm{pp}$.

1981. Dimorphism in ammonites. 257-273. In HOUSE, M. R. and SENIOR, J. R. (eds). The Ammonoidea: the evolution, classification, mode of life and geological usefulness of a major fossil group. Systematics Association, London, Special Volume, 18, xvi+593 pp.

- 1985. The evolution of the Jurassic ammonite family Cardioceratidae. Special Papers in Palaeontology, 33, 49-90.

- 2004. Some comments on the proposals for the GSSP of the Kimmeridgian Stage. International Subcommission on Jurassic Stratigraphy, Newsletter, 31, 21-24.

CONTEJEAN, C. 1859. Étude de l'étage kimméridien dans les environs de Montbéliard. Mémoires de la Société d'histoire naturelle du Doubs, 3rd Series, 4, $352 \mathrm{pp}$.

CONTINi, D. and HANTZPERGUE, P. 1973. Le Kimméridgien de la région de Montbéliard. Annales de Science de l'Université de Besançon, 18, 143-179.

COPE, J. C. W. 1995. Introduction to the British Jurassic. 1-7. In TAYLOR, P. D. (ed.). Field geology of the British Jurassic. Geological Society, London, 286 pp. 
DOHM, B. 1925. Über den oberen Jura von Zarnglaff i.P. und seine Ammoniten-fauna. Abhandlung Geologisches-Paläontolgisches Institut, Universität Greifswald, 2, 1-40.

DORN, P. 1925. Das Auftreten der Gattung "RingsteadiaSalfeld" im unteren Malm der nördlichen Frankenalp. Zeitschrift der Deutschen Geologischen Gesellshaft, 77, 529-524.

1930. Die Ammoniten-Fauna des untersten Malm der Frankenalb. 1, Die Perisphincten. Palaeontographica, 73, 107-175.

GALLOIS, R. W. 2005. On the Kimmeridgian (Jurassic) succession of the Normandy coast, northern France. Proceedings of the Geologists' Association, 116, 33-43.

GŁOWNIAK, E. 2002. The ammonites of the family Perisphinctidae from the Plicatilis Zone (lower Middle Oxfordian) of the Polish Jura Chain (central Poland); their taxonomy, phylogeny and biostratigraphy. Acta Geologica Polonica, 52, 307-364.

- and WIERZBOWSKI, A. 2007. Taxonomic revision of the perisphinctid ammonites of the Upper Jurassic (Plicatilis to Planula zones) described by Josef Siemiradzki (1891) from the Krakow Upland. Volumina Jurassica, 5, 31-137.

GRADSTEIN, F. M. and OGG, J. G. 2004. Geologic Time Scale 2004 - why, how and where next? Lethaia, 37, 175-181.

- SMITH, A. G., BLEEKER, W. and LOURANS, L. J. 2004. A new Geologic Time Scale, with special reference to Precambrian and Neogene. Episodes, 27, 83-100.

GYGY, R. A. 1995. Datierung von Seichtwassersedimenten des Späten Jura in der Nordwestschweiz mit Ammoniten. Eclogae geologicae Helveticae, 88, 1-58.

HANTZPERGUE, P. 1989. Les ammonites Kimméridgiennes du Haut-Fond d'Europe occidentale - biochronologie, systématique, évolution, paléobiogéographie. Cahiers de Paléontologie Centre National de la Recherche Scientifique, Paris, 1-427.

KUTEK, J. 1968. The Kimmeridgian and uppermost Oxfordian in the S.W. margins of the Holy Cross Mountains (Central Poland). Part 1, Stratigraphy. Acta Geologica Polonica, 18, 493-574.

MAKOWSKI, H. 1963. Problem of sexual dimorphism in ammonites. Palaeontologica Polonica, 12, 1-92.

MALINOWSKA, L. 1972. Middle and Upper Oxfordian in the north-west part of the Czestochowa Jurassic. Instytut Geologiczny, Biuletyn, 233, 4-67.

1991. Boreal faunal influences in Upper Oxfordian in north and central Poland. Prace Panstowowego Instytutu Geologicznego, $135,1-27$.

MATYJA, B. A. and WIERZBOWSKI, A. 1994. On correlation of Submediterranean and Boreal ammonite zonations of the Middle and Upper Oxfordian: new data from central Poland. Geobios, 17, 351-358.

1995. Biogeographic differentiation of the Oxfordian and Early Kimmeridgian ammonite faunas of Europe, and its stratigraphic consequences. Acta Geologica Polonica, 45, 1-8.

_ 1997. The quest for a unified Oxfordian/Kimmeridgian boundary: implications of the ammonite succession at the turn of the Bimmammatum and Planula zones in the Wielun Upland, central Poland. Acta Geologica Polonica, 47, 77-105.

— 2002. Boreal and Subboreal ammonites in the Submediterranean uppermost Oxfordian in the Bielawy section (northern Poland) and their correlation value. Acta Geologica Polonica, 52, 411-421.

— 2003. Correlation chart of standard chronostratigraphic ammonite zonations at the Oxfordian/Kimmeridgian boundary. International Subcommission on Jurassic Stratigraphy, Newsletter, 30, 25-27.

- and WRIGHT, J. K. 2006. The Sub-Boreal/Boreal ammonite succession at the Oxfordian/Kimmeridgian boundary at Flodigarry, Staffin Bay (Isle of Skye), Scotland. Transactions of the Royal Society of Edinburgh: Earth Sciences, 96 (for 2005), 387-405.

MELENDEZ, G. 2002. Oxfordian Working Group Report. International Subcommission on Jurassic Stratigraphy, Newsletter, 29, 11-15.

MESEZHNIKOV, M. S. 1969. Kimmeridgian ammonites. 99118. In SACHS, W. N. (ed.). The reference section of the Upper Jurassic deposits in the Kheta River Basin. Leningrad, Nauka, 208 pp. [In Russian].

— 1988. Oxfordian. 39-45. In KRYMHOLTS, G. Ya., MESEZHNIKOV, M. S. and WESTERMANN, G. E. G. (eds). The Jurassic ammonite zones of the Soviet Union. Geological Society of America, Special Paper, 223, 116 pp.

MORRIS, N. J. 1968. Palaeontological and stratigraphical studies in the Upper Jurassic rocks. Unpublished Dr. Phil. thesis, University of Oxford, $234 \mathrm{pp}$.

MORTON, N. and HUDSON, J. D. 1995. Field guide to the Jurassic of the Isles of Raasay and Skye, Inner Hebrides, NW Scotland. 209-280. In TAYLOR, P. D. (ed.). Field geology of the British Jurassic. Geological Society, London, $286 \mathrm{pp}$.

D'ORBIGNY, A. 1842-51. Paléontologie française. Terrains jurassiques. I. Céphalopodes. Victor Masson, Paris, 623 pp.

QUENSTEDT, F. A. 1887-88. Die Ammoniten des schwäbischen Jura III: Der Weisse Jura. E. Schweitzerbart'sche Verlagsbuchhandlung, Stuttgart, 818-1140.

ROGOV, M. A. and KISELEV, D. N. 2007. The Kimmeridgian of Russia and adjacent areas, its subdivision and correlation. Geological Institute of RAS, Moscow, 1-31.

ROŻAK, Z. and BROCHWICZ-LEWINSKI, W. 1978. Upper Oxfordian of Czestochowa; some new data. Bulletin de l'Académie Polonaise des Sciences, Série des Sciences de la Terre, 26, 47-51.

SALFELD, H. 1913. Certain Upper Jurassic strata of England. Quarterly Journal of the Geological Society of London, 69, 423432.

— 1914. Die Gliederung des oberen Jura in Nordwesteuropa. Neues Jahrbuch für Mineralogie, Beil Band B, 37, 125-246.

— 1917. Monographie der Gattung Ringsteadia (gen. nov.). Palaeontographica, 62, 69-84.

SCHAIRER, G. 1989. Ammoniten aus dem Braunen und Weissen Jura von Sengenthal. Mittelungen der Bayerische Staatssammlung für Paläontologie und Historische Geologie, 29, 109-131.

SCHINDEWOLF, O. H. 1925. Entwurf einer Systematik der Perisphincten. Neues Jahrbuch für Mineralogie, Geologie und Palaeontologie, Beilagerband B, 52, 309-343.

— 1926. Zur Systematik der Perisphincten. Neues Jahrbuch für Mineralogie, Geologie und Paleontologie, Beilagerband B, 55, 495-517. 
SCHNEID, T. 1940. Über Raseniiden, Ringsteadiiden und Pictoniiden des nördlichen Frankenjura, Abteilung III. Palaeontographica A, 91, 78-119.

SCHWEIGERT, G. and CALlOMON, J. H. 1997. Der bauhini-Faunenhorizont und seine Bedeutung für die Korrelation zwischen tethyalem und subborealem Oberjura. Stuttgarter Beiträge zur Naturkunde Serie B (Geologie und Paläontologie), 247, 69 pp.

SIEMIRADZKI, J. 1891. Fauna kopalna warstw oksfordzkich i Kimerydzkich w okregu Krakowskim i przyległych czesciach Królestwa Polskiego. Pamietnik Akademii Umietjetnosci $w$ Krakowie Wydzial Matematyczno-Przyrodniczy, 18, 1-92.

SPATH, L. F. 1924. On the Blake Collection of ammonites from Kachh, India. Palaeontologica Indica, New Series, 9, 1-29.

- 1935. The Upper Jurassic invertebrate faunas of Cape Leslie, Milne Land, East Greenland, I. Meddelelser om Grønland, 99, $1-80$.

STEINMANN, G. 1890. In STEINMANN, G. and DOEDERLEIN, L. Elemente der Paläontologie. Leipzig, 848 pp.

SYKES, R. M. and SURLYK, F. 1976. A revised ammonite zonation of the Boreal Oxfordian and its application in northeast Greenland. Lethaia, 9, 421-436.

— and CAllOMON, J. H. 1979. The Amoeboceras zonation of the Boreal Upper Oxfordian. Palaeontology, 22, 839-903.

SYLVESTER-BRADLEY, P. C. 1956. The new palaeontology. 1-8. In SYLVESTER-BRADLEY, P. C. (ed.). The species concept in palaeontology. Systematics Association Publication, London, 2, vi+145 pp.

TALBOT, M. R. 1974. Ironstones in the Upper Oxfordian of southern England. Sedimentology, 21, 433-450.

TAYLOR, S. P., SELLWOOD, B. W., GALLOIS, R. W. and CHAMBERS, M. H. 2001. A sequence stratigraphy of the Kimmeridgian and Bolonian stages (Late Jurassic): Wessex Weald Basin, southern England. Journal of the Geological Society, London, 158, 179-192.

TORNQUIST, A. 1896. Die degenerierten Perisphinctiden des Kimmeridge von Le Havre. Mémoire de la Societé paléontologique Suisse, 23, 1-44.

WALSH, S. L., GRADSTEIN, F. M. and OGG, J. G. 2004. History, philosophy and application of the Global Stratotype Section and Point (GSSP). Lethaia, 37, 201-218.

WIERZBOWSKI, A. 1970. Some Upper Jurassic ammonites of the genus Ringsteadia, Salfeld 1913, from central Poland. Acta Geologica Polonica, 20, 270-285.
1978. Ammonites and stratigraphy of the Upper Oxfordian of the Wielen Upland, central Poland. Acta Geologica Polonica, 28, 299-377.

—COE, A. L., hounslow, M. W., MAtyja, B. A., OGG, J. G., PAGE, K. N., WIERZBOWSKI, H. and WRIGHT, J. K. 2006. A potential stratotype for the Oxfordian-Kimmeridgian boundary: Staffin Bay, Isle of Skye, U.K. Volumina Jurassica, 4, 17-33.

WILCZYNSKI, A. 1962. La stratigraphie du Jurassique supérieur à Czarngłowy et Swietoszewo. Acta Geologica Polonica, 14, 3-112.

WILLIAMS, M. E. 2003. The development of hiatal surfaces in the Osmington Mills Ironstone Member of the Upper Jurassic Ringstead Formation of south Dorset, England. Proceedings of the Geologists' Association, 114, 193-210.

WRIGHT, J. K. 1980. The Oxfordian Stage. 61-76. In COPE, J. C. W. (ed.). A correlation of the Jurassic rocks of the British Isles, Part 2, Middle and Upper Jurassic. Geological Society, London, Special Report, 15, 109 pp.

— 1986. A new look at the stratigraphy, sedimentology and ammonite fauna of the Corallian Group (Oxfordian) of south Dorset. Proceedings of the Geologists' Association, 97, $1-21$.

— 1996. Perisphinctid ammonites of the Upper Calcareous Grit (Upper Oxfordian) of North Yorkshire. Palaeontology, 39, 433-469.

1998. New stratigraphical and palaeoecological data from the Sandsfoot Formation (Upper Oxfordian) of south Dorset. Proceedings of the Geologists' Association, 109, 15-24.

- 2003. New exposures of the Ampthill Clay near Swindon, Wiltshire, and their significance within the sequence of the Oxfordian/Kimmeridgian boundary beds in England. Proceedings of the Geologists' Association, 114, 97-121.

—_ 2001. British Upper Jurassic Stratigraphy (Oxfordian to Kimmeridgian). Geological Conservation Review Series No. 21, Joint Nature Conservancy Commission, Peterborough, 266 pp.

ZIEGLER, P. A. 1982. Post Hercynian plate reorganization in the Tethys and Artic-North Atlantic domains. 711-755. In IVIANSPEIZER, W. (ed.). Triassic-Jurassic rifting. Continental breakup and the origin of the Atlantic Ocean and passive margins. Developments in Geotectonics, 22(B). Elsevier, Amsterdam, 755 pp.

\section{APPENDIX}

1. Critical review of the main features used to distinguish between $P$. densicostata biosp. from the Inconstans Bed of Dorset and P. baylei biosp. from the 'Calcaires coquilliers' of the Normandy coast.

Hantzpergue (1989) and Schweigert and Callomon (1997) have proposed the following criteria to distinguish the two biospecies:

1. P. densicostata biosp. generally has more inflexible ribs, regularly disposed.
Inconstans Bed Pictonia are indeed commonly regularly ribbed (Pl. 9, fig. 2; Pl. 10, fig. 4). However, irregularly ribbed forms (Pl. 7, fig. 2; Pl. 9, fig. 5) and forms with flexible, slightly curved ribbing (Pl. 5, fig. 4; Pl. 9, fig. 1) are also common.

2. P. baylei biosp. becomes smooth earlier than P. densicostata biosp.

In fact, the reverse is true. Twenty-two specimens of $P$. densicostata biosp. that I have measured become smooth at an average of $102 \mathrm{~mm}$ diameter. Hantzpergue's (1989) photographs show that $P$. baylei biosp. becomes smooth at 
an average of $108 \mathrm{~mm}$ (eight specimens). These measurements are so close that the point of initiation of smooth phragmacone must be a very minor distinguishing feature of the two biospecies.

3. The stage of approximated ribbing is not confined to the nucleus in $P$. densicostata biosp., whilst it is in P. baylei biosp.

Specimens only rarely preserve the nucleus, and this is not a viable criterion to separate most specimens of Pictonia.

4. The ribbing of $P$. densicostata biosp. divides without attenuation of the secondaries. In P. baylei biosp., the secondaries fade immediately ventral of the point of division, and strengthen on the venter.

Hantzpergue (1989) does not state at what diameter this criterion is present. Prior to $55-60 \mathrm{~mm}$ diameter, no fading of the ribbing is visible in P. densicostata biosp. However, between $60 \mathrm{~mm}$ and the end of the ribbing, fading of the ribbing ventral to bifurcation points and on the venter is present in almost all specimens (e.g. Pl. 10, fig. 4). Use of this criterion to separate the two biospecies is thus difficult.

5. The cross-section of P. densicostata biosp. is more oval.

The cross-section of Inconstans Bed Pictonia at $c$. $50 \mathrm{~mm}$ diameter in fact varies from extremely depressed, nearly twice as thick as high, to compressed, with height greater than thickness. However, the distinctive, flat-sided forms resembling the holotype of $P$. baylei are not present in the Inconstans Bed, P. densicostata biosp. consistently having the rounded whorl side only present in some P. baylei biosp.

6. P. densicostata biosp. has denser ribbing.

The data are:-

P. baylei biosp. (from Hantzpergue, 1989): 24 specimens, average $26.7 \mathrm{rpw}$ between $70-80 \mathrm{~mm}$ diameter.

P. densicostata biosp.: 14 specimens, average $30.2 \mathrm{rpw}$ between $70-80 \mathrm{~mm}$ diameter. This is by far the clearest distinction, although several specimens from Dorset fall below the Normandy average.

7. Ribbing of $P$. densicostata biosp. is finer, sharper and divides at two thirds of the whorl height. P. baylei biosp. has rounder, coarser ribbing dividing at the middle of the whorl side.

The ribbing of Pictonia from the Inconstans Bed in fact varies from fine, dense and sharp to blunt and gently rounded. However, almost all specimens have the bifurcation point situated at three fifths (not two thirds) of the whorl height. The height of division of the secondaries in P. baylei biosp. can vary - most specimens do have the division point in the middle of the whorl side, although in some specimens (OUM JZ 701; Hantzpergue, 1989, pl. 22a) division is at three fifths of the whorl height.

\section{List of specimens of Ringsteadia and Microbiplices examined}

R. pseudoyo: five specimens (BGS GSM72900, NHM 24089 (lectotype), C88651, C88657, OUM J14822) from the Marston Ironstone of Wootton Bassett. 21 specimens from the Marston Ironstone of South Marston (NHM 36960 (paratype), C71125,
C88665d, C89059, OUM J14616, SM25, 44, 53, 58, 192, 227, 228, 251, 252, 254, 262, 275, 277, 289, 290, 291). All specimens prefixed SM collected from the Keypoint site. One specimen (CAMSM X 50142) from the Westbury Ironstone of Westbury. Two specimens (OUM J21186, J37527) from the Osmington Mills Ironstone (Ringstead Coral Bed) of Ringstead Bay, and one specimen (BGS Zm2295) from the Osmington Mills Ironstone of the East Fleet section.

R. sphenoidea: Holotype (NHM C41691) from the Marston Ironstone of Wootton Bassett. Seven specimens (SM43, 46, 84, 96, 146, 269, 270) from the Marston Ironstone at the Keypoint site, South Marston.

R. brandesi: Three specimens from the Marston Ironstone of Wootton Bassett (NHM 15425 (paratype), C36972, C4122695). Fifty one specimens (NHM C50750, 50770 (lectotype), SM19, $21,26,28,33,35,38,45,47,51,52,73,81,83,90,95,113,118$, $121,122,123,124,127,132,138,142,151,153,154,155,180$, $182,185,208,229,231,244,245,246,247,257,260,261,263$, 266, 272, 274, 292, YORYM:2004.179) from the Marston Ironstone of South Marston. Specimens prefixed SM collected at the Keypoint site. Five specimens from the Westbury Ironstone (D 1702, GSM7717, BGS GSM97553, BGS HBW2644, NHM C26457). Five specimens from Unit III of the Sandsfoot Grit, four from Sandsfoot Castle (DC58, DC94, ic105, SMC J47616) and one from the East Fleet section (DC146).

R. anglica: five specimens (BGS GSM25502 (lectotype), GSM97551, NHM C41696, SMC J44981, UR 10895) from the Westbury Ironstone. NHM C50768 (paratype) from the Ampthill Clay (?Marston Ironstone) of Shrivenham and NHM C322 (paratype) from 'Wiltshire'. Seven specimens (NHM C4864, SM42, 72, 78, 88, 135, 250) from the Marston Ironstone of South Marston. Specimens prefixed SM collected at the Keypoint site.

R. pseudocordata: 13 specimens from the Westbury Ironstone (BGS 2649Hbr, GSM8254, GSM46264 (holotype), GSM97554, D1704, OUM J21235, J21236, J21237, J21238, J21239, J21240, SMC J44980, J44984). 45 specimens from the Marston Ironstone of South Marston (OUM J14615, SM16, 23, 27, 32, 41, 49, 55, $56,72,74,75,79,114,116,117,119,120,128,145,183,188$, 189, 195, 209, 230, 232, 249, 253, 259, 264, 265, 287, 288, 293). All specimens prefixed SM collected from the Keypoint site. One specimen (NHM C41695) from the Marston Ironstone of Wootton Bassett. One specimen from the Sandsfoot Grit of Sandsfoot Castle (DC94).

R. pseudocordata var. nudus: 10 specimens from the Marston Ironstone of the Keypoint site (SM31, 48, 57, 76, 85, 187, 191, 206, 244, 276).

R. marstonensis: 38 specimens (NHM C15427 (holotype), C71124, C88665c, C88665f, SM20, 22, 24, 29, 30, 34, 37, 39, 50, $59,61,62,64,65,66,68,71,77,82,89,115,133,134,136,137$, $147,148,150,179,201,255,258.273,285)$ from the Marston Ironstone of South Marston. Specimens prefixed SM collected at the Keypoint site. Eight specimens from the Westbury Ironstone of Westbury (BGS GSM97555, NHM C26451, C88650, OUM J16734, RHUL ic972, SMC J44971, J44983, J44987), one speci- 
men (DC119) from the Sandsfoot Grit of Sandsfoot Castle, Weymouth, and one specimen (DC126) from the Osmington Mills Ironstone (Ringstead Coral Bed) of Ringstead Bay.

R. bassettensis: Holotype (NHM C15426) from the Marston Ironstone of Wootton Bassett. Thirteen specimens (SM40, 63, 67, 69, $129,143,144,149,193,210,256,284,286)$ from the Marston Ironstone of the Keypoint site, South Marston. Two specimens from the Westbury Ironstone of Westbury (RHUL ic973, SMC J44972).

R. bassettensis var. strattonensis: Three specimens (SM60, 190, 248) from the Marston Ironstone at the Keypoint site, Swindon, and one specimen from the Marston Ironstone of this general area (NHM C71123). One specimen (DC142) from the Sandsfoot Grit, Unit III, of the East Fleet section.

R. frequens: One specimen (NHM C24092, lectotype) from the uppermost Ampthill Clay of Wootton Bassett. 20 specimens (DC62, 141, BGS Zf3727, JHC 1203, NHM C3344, C12073, C23881, C82419, C93796, OUM J13104, J13478, J19456, SMC J13479, J44958, J44959, J44960, J44964, J44965, J44966, J44967) from the Osmington Mills Ironstone of Osmington, Ringstead Bay, Sandsfoot Castle and the East Fleet section. One specimen from the Ampthill Clay of the Bourton Bypass.

R. evoluta: 27 specimens (DC122, 125, 139, BGS GSM5770, GSM3864, Zf3725, JHC 931, 932, 934, 935, 936, NHM C3306, C14664, C19467, C82416, C82417, C82418, C93794, OUM J14662, J14666, J14700, J14923, J21175, J37756, SMC J44963, J44969, J44973) from the Osmington Mills Ironstone of Ringstead Bay, Osmington and the Fleet Lagoon. Twenty specimens from the Ampthill Clay of the Bourton Bypass, north Dorset.

P. densicostata s.s.: Holotype (BGS GSM25481) from the Inconstans Bed of Ringstead Bay, Dorset. Sixteen further specimens (DK9, GSM Zf3724, OUM J14672, J14683, J14686, J14687, J14693, J14697, J14924, J17831, J21219, J37716, J44693, J67110, SMC J47864, J47867) from the Inconstans Bed of Ringstead Bay.

P. densicostata var. dorsetensis: Type of var. (DK31) from the Inconstans Bed of Black Head, and eight specimens (DK6, 8, 24, GSM 82917, OUM J14919, J21217, SMC J47869, J47912) from the Inconstans Bed of Ringstead Bay, three from Wootton Bassett (GSM Y2904, OUM J67111, SMC J29068), and one from the Kimmeridge Clay of North Yorkshire (GSM Y1679).
P. densicostata var. praebaylei: Type of var. (SMC J47870) and 37 further specimens (DK5, BGS 1666HBW, BGS GSM25485, NHM C93791, C93795, OUM J14674, J14675, J14676, J14677, J14679, J14682, J14688, J14689, J14690, J14691, J14694, J14695, J14696, J14921, J17831, J20063, J21181, J37713, J37714, J37717, J37718, J67138, SMC J47444, J77858, J47859, J47860, J47861, J47862, J47863, J47871, J47873, J47913) from the Inconstans Bed of Ringstead Bay. One specimen (SMC J47861) from the Nana Bed of Ringstead Bay.

P. densicostata var. grandicostata: Type of var. (SMC J47868) and three further specimens (DK32, NHM C93792, OUM J14678) from the Inconstans Bed of Ringstead Bay.

P. seminudata s.s.: Holotype (BGS GSM47535) in the matrix of the Inconstans Bed of Ringstead Bay, Dorset. 11 topotypes (BGS GSM3018, GSM25500, Zf3723, Zf3726, NHM C3316, C23885, OUM J13337, J21218, J29499, 67109, J69569).

P. seminudata var. ringsteadensis: Type of var. (DK8) and eight further specimens (DK4, 11, NHM C77998, C82407, C93793, OUM J20063, J37712, SMC J47448) from the Inconstans Bed of Ringstead Bay.

Microbiplices anglicus: 22 specimens (BGS GSM30627 (holotype), DC55, 56, 61, 63, RHUL ic376a, ic376b, ic376d, ic376e, ic377, NHM C19475, C69773, C82013, C82014, C82015, C82017, C82018, C82019, C82023, C82025, C82026, C82427) from the Sandsfoot Grit of Sandsfoot Castle, and one specimen each from the Sandsfoot Grit of the East Fleet (DC97), Black Head (DC61) and Ringstead Bay (DC140). One specimen from the Marston Ironstone (SM163) and four specimens (SM297, 298, 299, 300) from the overlying Ampthill Clay of the Keypoint site, south Marston; three specimens (NHM 26461 (figd. Arkell, 1947a, pl. 76, figs 1a,b), 25367a, 25367b) from the Westbury Ironstone.

Microbiplices triplicata: Three specimens from the Osmington Mills Ironstone of the Fleet Lagoon (NHM C75301, C75302, C82034).

Prorasenia bowerbanki: One specimen (SF1) from the basal Kimmeridgian Oxytoma Cementstone of South Ferriby Pit, Lincolnshire, and one specimen (DK35) from the basal Kimmeridge Clay of the Bourton Bypass, Dorset.

Prorasenia cf. hardyi: Four well-preserved microconchs from the Inconstans Bed of Ringstead Bay. (SMC J47351, DK10, 33, 34). 